University of Pennsylvania Carey Law School

Penn Law: Legal Scholarship Repository

Faculty Scholarship at Penn Law

2004

\title{
A Normative Theory of Bankruptcy Law: Bankruptcy as (is) Civil Procedure
}

Charles W. Mooney Jr.

University of Pennsylvania Carey Law School

Follow this and additional works at: https://scholarship.law.upenn.edu/faculty_scholarship

Part of the Bankruptcy Law Commons, and the Litigation Commons

\section{Repository Citation}

Mooney, Charles W. Jr., "A Normative Theory of Bankruptcy Law: Bankruptcy as (is) Civil Procedure" (2004). Faculty Scholarship at Penn Law. 18.

https://scholarship.law.upenn.edu/faculty_scholarship/18

This Article is brought to you for free and open access by Penn Law: Legal Scholarship Repository. It has been accepted for inclusion in Faculty Scholarship at Penn Law by an authorized administrator of Penn Law: Legal Scholarship Repository. For more information, please contact PennlawIR@law.upenn.edu. 


\title{
A Normative Theory of Bankruptcy Law: Bankruptcy As (Is) Civil Procedure
}

\author{
Charles W. Mooney, Jr.*
}

\begin{abstract}
This paper develops a normative theory of bankruptcy law called "procedure theory." The core of procedure theory is that bankruptcy law exists in order to maximize the recoveries for holders of legal entitlements ("rightsholders") in respect of a financially distressed debtor. Bankruptcy law in the United States is a branch of civil procedure and the jurisdiction of federal courts. Procedure theory holds that it generally is wrong in bankruptcy to redistribute a debtor's wealth away from its rightsholders to benefit third-party interests, such as at-will employees and the general community. It also generally is wrong to rearrange priorities in bankruptcy as among a debtor's rightsholders. Procedure theory explains what bankruptcy law is supposed to achieve, not how bankruptcy law is to achieve its proper ends.
\end{abstract}

Procedure theory draws support from three perspectives. First, it argues that it is incoherent to provide different substantive rules in bankruptcy when those substantive rules are equally applicable outside bankruptcy. This incoherence offends the interest of justice. Second, procedure theory is supported by the Erie doctrine in federal courts and considerations of federalism. Basic substantive law rules should not vary depending on the forum in which a proceeding is conducted-state court or bankruptcy

* Charles A. Heimbold Jr., Professor of Law, University of Pennsylvania Law School. I am grateful to the Handler Foundation and to the University of Pennsylvania Law School for generous research support. I also wish to thank Laura Bartell, Stephen Burbank, David Carlson, Geoffrey Hazard, Melissa Jacoby, Edward Janger, Stephen Perry, Reed Shuldiner, Paul Shupack, Charles Tabb, Elizabeth Warren, participants at faculty workshops at the University of Arizona James E. Rogers College of Law, the University of Illinois College of Law, and the College of William and Mary, Marshall-Wythe School of Law, and participants at the 2003 faculty retreat of the University of Pennsylvania Law School for helpful suggestions and comments on earlier drafts, as well as Erin Miller, J.D. 2001, University of Pennsylvania Law School; Chi-Wei Huang, LL.M. 2000, S.J.D. candidate. University of Pennsylvania Law School; Derek Santos, J.D. 2003, University of Pennsylvania Law School; Michael Doak, J.D. 2003, University of Pennsylvania Law School; and Sun Lim, J.D. 2004, University of Pennsylvania Law School, for valuable research assistance. Errors that remain are mine. 
court. Third, a public choice analysis reveals the enormous power of the bankruptcy bar. The Judiciary Committees in Congress and the bankruptcy courts are improper venues for the development of law that is not bankruptcy specific.

A justification for bankruptcy law must be that, as a collective proceeding, it can maximize or enhance recoveries and benefits for rightsholders when compared to nonbankruptcy law. This Article examines a number of important features of United States bankruptcy law that conflict with (or at least appear to conflict with) procedure theory. It generally rationalizes procedure theory with several of these features. In several other cases, procedure theory calls for a modification of current law.

\section{Table of Contents}

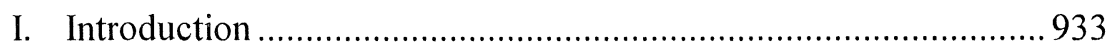

II. Basic Elements of Procedure Theory.......................................... 936

A. Normative Theory and Bankruptcy Policy ............................ 936

B. The Ends and Principles of Procedure Theory of

Bankruptcy Law



2. Respecting Nonbankruptcy Entitlements of

Rightsholders: Procedure Theory in Context

C. Situating Procedure Theory in the Normative

Debates on Bankruptcy Philosophy and Policy

D. Why Bankruptcy?

1. Preserving, Increasing, and Fairly Distributing

Value

2. Procedure Theory and the Effectiveness of Bankruptcy Law.

III. The Normative Case for Procedure Theory

A. Interests of Rightsholders Versus Interests of Nonrightsholders: Employees, Rehabilitation, and Community .

B. Interests of Rightsholders Inter Se, Including Priorities ........967

C. The Philosophical and Jurisprudential Account of Procedure Theory....

D. The Procedural and Federal Court Jurisdiction Account of Procedure Theory.....

E. A Public Choice Account of Procedure Theory 1000 
IV. Bankruptcy Law Under Procedure Theory: Consistencies and (Apparent or Real) Inconsistencies

A. Property of the Estate ......................................................... 1013

B. Claims and Nonclaim Entitlements ..................................... 1014

C. Equal Treatment for Similarly-Situated

Rightsholders: Pro Rata Sharing........................................ 1022

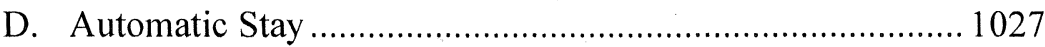

E. Trustee in Bankruptcy's Avoiding Powers .......................... 1028

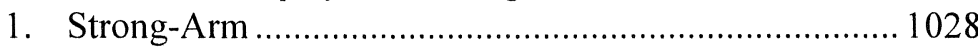

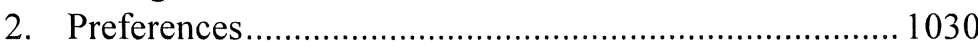

3. Fraudulent Transfers ...................................................... 1034

F. Assumption and Rejection of Executory Contracts

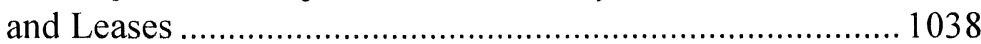

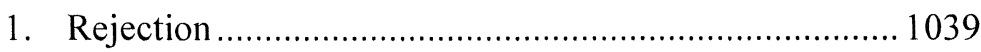

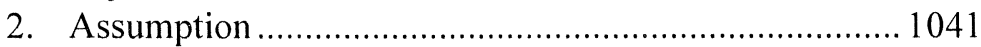

3. Assignment ........................................................... 1044

4. Timing and Delay ................................................... 1045

G. The Individual Debtor's Discharge and the "Fresh-Start"

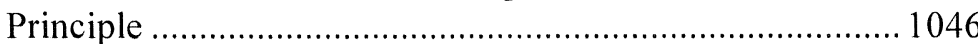

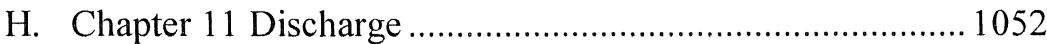

I. Priority Claims Under Bankruptcy Code Section 507 ......... 1053

J. Adequate Protection for Undersecured Creditors ................ 1058

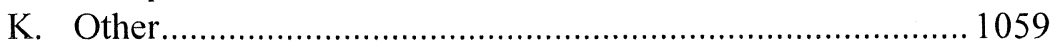

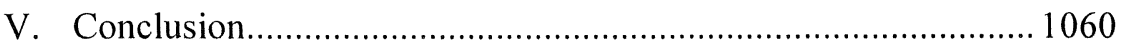

\section{Introduction}

During the past two decades, contemporary bankruptcy scholars have engaged in extensive academic debates that have played out in many law review articles and several books. 'This Article engages important aspects of those debates. It expands on a theme that I suggested almost a decade ago. ${ }^{2}$ It describes and defends a

1. See infra Part II.C (presenting the debate among bankruptcy scholars).

2. Charles W. Mooney, Jr., Hosing Down Senior Claims with a Quicker and Dirtier Chapter 11, 72 WASH. U. L.Q. 1153, 1158 (1994) (commenting on Lynn M. LoPucki \& William C. Whitford, Compensating Unsecured Creditors for Extraordinary Bankruptcy Reorganization Risks, 72 WASH. U. L.Q. 1133 (1994)). The article states:

When a claimant ... employ[s] the judicial system to recover on a claim, the end game converts the obligor's property into property of the claimant, such as by levy of execution, sheriff's sale, and so forth. Bankruptcy is a part of that system. Its 
normative theory of bankruptcy law that views the core role of bankruptcy law as the maximization of recoveries for those with nonbankruptcy legal entitlements relating to financially distressed debtors. ${ }^{3}$ Stated otherwise, bankruptcy law should exist, essentially, in order to serve the interests of the holders of nonbankruptcy legal entitlements. I call these holders "rightsholders." ${ }^{4}$ For reasons developed fully below, I refer to this normative theory as "procedure theory."

This Article focuses primarily, but not exclusively, on business bankruptcy. It is in business bankruptcies, in particular in Chapter 11, that the greatest temptations may exist to favor extraneous social goals at the expense of a debtor's rightsholders. ${ }^{5}$ It also focuses primarily on bankruptcy law in the United States, but

domain is an orderly procedure that should allow claimants to obtain at least as much as they would have obtained in the nonbankruptcy enforcement process, and perhaps more .... Bankruptcy is civil procedure - no less but absolutely no more. Id.

3. References to bankruptcy are intended to encompass not only liquidation under Chapter 7 of the Bankruptcy Code, but also reorganization under Chapter 11. 11 U.S.C. $\$ \$ 701$ et seq. (2000); 11 U.S.C. $\$ 1101$ et seq. (2000).

4. Much of the ongoing debate about bankruptcy policy centers on the question whether the core principle of bankruptcy is the maximization of creditor wealth or whether it has more expansive goals. See infra Part II.C (discussing the role of procedure theory in the normative debates on bankruptcy philosophy and policy). In his critique of the use of bankruptcy for expansive goals, Christopher Frost contrasts a debtor's "investors" with its "non-investors," but that terminology does not seem to capture involuntary creditors (although Frost clearly intends that they be encompassed as "investors"). Christopher W. Frost, Bankruptcy Redistributive Policies and the Limits of the Judicial Process, 74 N.C. L. Rev. 75, 80 n.16 (1995). I use the term "rightsholders" to encompass the holders of all legal entitlements vis-a-vis a debtor, including but not limited to "creditors," such as shareholders, governmental regulators, and the beneficiaries of laws and regulations that apply to debtors. Even so, "creditor" is quite broadly defined in the Bankruptcy Code to include entities that hold "claims." 11 U.S.C. § 101(10) (2000) (defining "creditor"). "Claim" is defined broadly to mean:

(A) right to payment, whether or not such right is reduced to judgment, liquidated, unliquidated, fixed, contingent, matured, unmatured, disputed, undisputed, legal, equitable, secured, or unsecured; or

(B) right to an equitable remedy for breach of performance if such breach gives rise to a right to payment, whether or not such right to an equitable remedy is reduced to judgment, fixed, contingent, matured, unmatured, disputed, undisputed, secured, or unsecured.

11 U.S.C. $\$ 101(5)(2000)$.

5. See Elizabeth Warren, Bankruptcy Policy, 54 U. CHI. L. REV. 775, 776-77 (1987)

(discussing competing goals of bankruptcy). Professor Warren states:

Professor [Douglas] Baird and I have agreed to debate the basis of bankruptcy policy in the context of business bankruptcy. While we both believe that the principles we discuss have significance in a consumer setting as well, we recognize that additional issues should be a part of a discussion about consumer bankruptcy policy and that those issues would make the discussion even more complex.

Id. 
the core insights of procedure theory should be robust in the consumer bankruptcy setting as well as under the laws of any jurisdiction.

Part II of this Article provides an overview of the principles embraced by procedure theory, including its ends and basic features. It also situates procedure theory in the ongoing normative debates about bankruptcy philosophy and policy and distinguishes procedure theory from much of the other bankruptcy scholarship that has been featured in these debates. In particular, it addresses academic critiques of the path-breaking scholarship of Douglas Baird and Thomas Jackson and identifies procedure theory's similarities to, and differences from, Baird and Jackson's theoretical work. Part III makes the normative case for procedure theory and identifies sources and bases of its normative content. It first addresses the application of procedure theory to the interests of a debtor's rightsholders versus those of nonrightsholders and then as to the rights of a debtor's rightsholders inter se. It then fashions a normative account of procedure theory based on jurisprudential and philosophical grounds, on theoretical underpinnings of civil procedure law and federal court jurisdiction, and on a public choice analysis. Part IV addresses bankruptcy law as a procedural system for maximizing recoveries and benefits for a debtor's rightsholders. It considers justifications for bankruptcy law as a special branch of procedural law. It also identifies several aspects of bankruptcy law that alter or appear to alter nonbankruptcy entitlements. It explains how some of these alterations may be coherent under, and entirely consistent with, procedure theory. Part IV also tests procedure theory against various controversial elements of bankruptcy law and identifies some aspects of current bankruptcy doctrine that offend procedure theory. In this way it explores the explanatory and instructional powers of procedure theory to suggest doctrinal reforms. Part V then concludes the Article.

A complete account of procedure theory first would address all aspects of nonbankruptcy law as affected by all aspects of bankruptcy law. Second, it would identify and call for retention of only those aspects of bankruptcy law that comport with procedure theory and the elimination of those that do not. Third, it would compare and contrast procedure theory with all of the theoretical academic literature on bankruptcy during (at least) the past two-plus decades. Fully realized, that project would be not only enormously ambitious but also quite lengthy. Instead, this Article will be satisfied to examine the intersection of some of the more important aspects of nonbankruptcy law with some of the more significant aspects of bankruptcy law, and it necessarily will be selective in the breadth and depth of its consideration of the literature. This initial project provides a platform for subsequent work that will target narrower, 
more discrete areas of nonbankruptcy law and bankruptcy law with correspondingly greater depth and detail.

\section{Basic Elements of Procedure Theory}

\section{A. Normative Theory and Bankruptcy Policy}

This Article should pose and answer several questions before outlining the content and significance of procedure theory. For example: What is a normative theory of bankruptcy law? What distinguishes a normative theory of bankruptcy law from other approaches - both normative and non-normativeto examining and providing content to bankruptcy policy? What is it that a normative theory of bankruptcy law does and does not do?

In his 1996 article, Professor Donald Korobkin explained how normative theory could contribute to the ongoing policy debates about bankruptcy law. ${ }^{6}$ For the most part, I subscribe to Korobkin's taxonomy of bankruptcy scholarship, which may be non-theoretical or theoretical and non-normative or normative. ${ }^{7}$ A normative theory can provide a compelling story about what the means and ends of bankruptcy law should be. ${ }^{8}$ Although a normative theory also may provide explanatory insights concerning current bankruptcy law, it need not do so (at least not with perfect precision) to be successful. As Korobkin has observed, "[t]he very object of a normative theory is to establish a critical perspective on current law." ${ }^{9}$ Obviously, normative theory is based on

6. See generally Donald R. Korobkin, The Role of Normative Theory in Bankruptcy Debates, 82 Iowa L. REV. 75 (1996).

7. Id. at 121-22. Actually, Korobkin also offers even richer taxonomies, but those mentioned in the text are sufficient for present purposes. Although I find Korobkin's analysis of bankruptcy scholarship both insightful and useful, as will become clear below, I reject Korobkin's own normative theory as, inter alia, incoherent. See infra notes 155-65 and accompanying text (criticizing Donald R. Korobkin, Rehabilitating Values: A Jurisprudence of Bankruptcy, 91 COLUM. L. REV. 717 (1991) [hereinafter Rehabilitating Values] and Donald R. Korobkin, Contractarianism and the Normative Foundations of Bankruptcy Law, 71 TEX. L. REV. 541 (1993) [hereinafter Contractarianism]).

8. See Korobkin, supra note 6, at 111-12 (discussing the value of normative theory).

9. Id. at 98. Oddly, Korobkin criticizes Baird and Jackson's "common pool account" of bankruptcy, which Korobkin acknowledges is a "system-based" normative theory, because that account "fails as an explanation" of current law. Id. at 112-16 (emphasis added); see also KAREN GROSS, FAILURE AND FORGIVENESS: REBALANCING THE BANKRUPTCY SYSTEM 2 (1997) [hereinafter FAILURE] ("Despite the zeal and stridency of the bankruptcy system's critics, many of them have not confronted, and some have not even recognized, this prescriptive challenge, namely, addressing what bankruptcy law ought to be in contemporary American society.") (footnote omitted). 
values. As a theory, moreover, normative theory may offer guidance for resolving competing values. ${ }^{10}$ To be successful, a normative theory of law must identify the nature and source of the values and principles on which it is based and also must offer some meaningful prescriptive force concerning how law should be altered or preserved. But it need not resolve every detail of a large and comprehensive statute such as the Bankruptcy Code. ${ }^{11}$ Put in context, procedure theory prescribes what bankruptcy law should achieve, but it does not dictate precisely how to accomplish its goals most effectively, except in a very general fashion. ${ }^{12}$ Indeed, there is no reason to suppose that a single means or structure can reach the ends of bankruptcy law.

The following subpart outlines the essential attributes of procedure theory. Procedure theory identifies the ends that bankruptcy law is supposed to achieve. Essential goals are the cornerstone of any normative theory of bankruptcy law. Procedure theory holds that the goal of bankruptcy law as a system is to maximize the recoveries or other benefits for the debtor's rightsholders. A corollary of this principle recognizes the procedural character of procedure theory: Bankruptcy law should take substantive legal entitlements of rightsholders as it finds them, honoring both powers and limitations under nonbankruptcy law.

\section{B. The Ends and Principles of Procedure Theory of Bankruptcy Law}

\section{Bankruptcy as Civil Procedure}

Procedure theory conceptualizes bankruptcy law as a subset of the law of civil procedure. ${ }^{13}$ Thus, before turning in earnest to what it is that bankruptcy

10. See Korobkin, supra note 6, at 111 ("[N]ormative theory attempts to obtain a critical perspective on the means that we use and the ends that we seek.").

11. Id. (discussing normative law). Korobkin states:

[U]nlike a predictive theory, a normative theory does not undertake to identify the best or most efficient proposal for achieving a particular end. Certainly, a normative theory serves to criticize values that underlie such proposals, and therefore it may have legislative implications. But it is not less successful as a normative theory if the theorizing results in normative prescriptions rather than specific legislative advice.

Id. at 98 .

12. See infra Part II.D (explaining how bankruptcy law may maximize recoveries for rightsholders).

13. See infra Part III.D (addressing in some detail below the procedural and federal courts account of procedure theory). For convenience I intend an expansive meaning for references to "civil procedure" and "procedure." For example, I realize that "civil procedure" does not necessarily include the subject matter jurisdiction of courts, but I intend the term to reach that 
law should do (and does), it is helpful to focus on what it is that civil procedure should do (and does). It is the relationship of procedural law to substantive doctrinal law that gives content to the nonbankruptcy legal entitlements of rightsholders. Books on civil procedure normally begin with an identification of the substance-procedure dichotomy. ${ }^{14}$ A standard conceptualization is that substantive law creates legal rights and duties and procedural law provides a means to enforce the substantive rights and duties. ${ }^{15}$ Procedural law serves substantive law, the latter having primacy in this sense. ${ }^{16}$ Although a significant role of procedural law is the actual resolution of disputes between and among parties, it also is a "social process." ${ }^{17}$ Procedural law must provide

far. Procedure theory also embraces civil procedure as consisting of more than merely "procedural" rules and as encompassing as well the law of remedies. For now, it is useful to note one response to the question, "Why procedure?" In developing a theory it is helpful to base or ground the theory in a familiar field from which direct or analogous wisdom and insight might be derived. Obviously, bankruptcy is bankruptcy, and it has some distinctive features. See infra Parts II.D and IV (discussing the distinctive features of bankruptcy). Ultimately, procedure theory must stand or fall on its own normative bottom and not on whether one agrees or disagrees that it is a branch of civil procedure.

14. See, e.g., Fleming James, JR. \& Geoffrey C. Hazard, JR., Civil Procedure $\$ 1.1$, at 1-2 (3d ed. 1985) (presenting the substance-procedure difference); RICHARD L. MARCUS ET AL., CIVIL PROCEDURE: A MODERN APPROACH 1 (1989) (same). I am aware, of course, that only the most naive would believe that every legal rule or standard could be labeled definitively as "procedural" or "substantive" or that a meaningful understanding of the rule or standard could be immanent in the label. But that is not to say that the dichotomy is nonexistent or meaningless.

15. MARCUS ET AL., supra note 14, at 1 (discussing the standard conceptualization of substantive law). The text states:

Law can be conveniently divided into two categories, substance and procedure. Substantive law defines legal rights and duties in everyday conduct. Thus, it is a rule of substantive law that an individual will be liable in damages for injuring another person through negligence. Procedural law sets out the rules for enforcing substantive rights in the courts .... The line between substance and procedure is sometimes difficult to draw, but the basic distinction is central to the theory of procedure.

Id.

16. JAMES \& HAZARD, supra note $14, \S 1.1$, at 2 (discussing substantive law). The text states:

It is a means of augmenting other inducements that persons have for conducting their relations in conformity with the substantive law's prescriptions. As Hepburn says: "As its name 'adjective' imports, it exists for the sake of something else-for the sake of the 'substantive law' [quoting HEPBURN, THE HISTORICAL DEVELOPMENT of Code Pleading 19, 20 (1897)].

Id.

17. See id. $\$ 6.1$, at 279-80 ("Civil litigation is a social process, one of the techniques by which society adjusts to the conflicts that arise from shortages of resources, misunderstandings and antipathies among members of society, and social change over time."). 
assurances to all parties that the process is fair and that they will have an opportunity to present a case. ${ }^{18}$ Moreover, procedural law should provide courts that are available to parties at a reasonable cost and that act with reasonable swiftness. It should also result in final resolutions that provide repose and security. ${ }^{19}$

The social significance of civil procedure embraces much more than a means of judicial enforcement of private rights. It is inextricable from and essential to those rights. ${ }^{20}$ For example, the quality of a tort claim or contract claim necessarily, and obviously, is a function of the enforceability of the claim - whether a court would be legally obliged to give a remedy to the holder of the claim. But it also is a function of whether or not there exists a judicial system available to the claimant pursuant to which the claimant in fact can both obtain a legal remedy (such as a money judgment) and exercise effective judicial enforcement (such as execution and sheriff's sale or garnishment). To the extent that effective procedural remedies are not available, the substantive doctrine of tort and contract law provided by lawgivers-legislatures, judges, and administrators-is undermined. ${ }^{21}$

An understanding of the role of procedural law is informed by the comparative work of Kathryn Hendley. Among other things, Hendley addresses the relationship between substantive and procedural law in her insightful book on the role of law in the former Soviet society. ${ }^{22}$ Her study focuses on "law in action"- - how "law was actually being implemented at the

18. Id. $\S 1-1$, at 2-3.

19. Id. ("[P]rocedure should not be too costly in time and money.").

20. See supra note 16 (discussing substantive law); see also Jerome Michael \& Mortimer J. Adler, The Trial of an Issue of Fact: I, 34 COLUM. L. REV. 1224, 1230 (1934) (discussing judicial enforcements of rights). The text states:

The procedural law, like the substantive law, should serve the end of justice. Whether or not it does is the root of our criticism of it. But the procedural law is subordinate to the substantive law. Justice cannot be achieved by just laws alone but only by a just administration of just laws.

Id.

21. See Stephen B. Burbank, The Bitter With the Sweet: Tradition, History, and Limitations on Federal Judicial Power - Case Study, 75 NOTRE DAME L. REV. 1291, 1292-93 (2000) ("[P]rocedure is power, whether in the hands of lawyers or judges . . . . Substantive rights, including constitutional rights, are worth no more than the procedural mechanisms available for their realization and protection."). This statement explains why parties in substantial transactions normally insist on receiving legal opinions, including a "remedies" opinion intended to provide assurances to the opinion recipient that a judicial remedy will be available. See, e.g., Committee on Legal Opinions, Third-Party Legal Opinion Report, Including the Legal Opinion Accord, of the Section of Business Law, American Bar Association, 47 BUS. LAW. 167, 198-201 (1991) (discussing the remedies section of a legal opinion).

22. Kathr yn Hendey, Trying to Make LaW Matter (1996). 
grassroots level." ${ }^{23}$ Hendley argues that law can matter either reciprocally or coercively. Law matters in the reciprocal sense (Hendley's preferred sense) when it serves "as a means of constraining official power, vindicating citizens' grievances, and facilitating private transactions. ${ }^{24}$ On the other hand, law matters in a coercive sense when its effect and design is to impose social order. $^{25}$ Hendley identifies the "defining elements of law that matters reciprocally" as "legitimacy, accessibility, and efficacy."26 These elements are affected by the nature of the enforcement system available to litigants. If the applicable enforcement system is adequate, the system enhances legitimacy, accessibility, and efficacy. A defective enforcement structure detracts from these elements. ${ }^{27}$

Hendley explains that only by understanding the specific characteristics of the gap between the written law and the law as implemented can one realistically evaluate the obstacles to the realization of a legal order in which law matters reciprocally, not coercively. ${ }^{28}$ Under the Soviet regime, the low level of trust in the basic fairness of law-both substantively and procedurally - resulted in a great reluctance of Soviet citizens to turn to the legal system for vindication of their rights. ${ }^{29} \mathrm{~A}$ widely held belief that the judicial system or judge is inherently biased or corrupt discourages resort to the courts. ${ }^{30}$ Substantive doctrine is meaningless in a system in which an aggrieved party cannot obtain effective relief in the courts. Significantly, the inadequacy of available remedies and judicial enforcement power also contributed to this reluctance, thereby rendering the Soviet courts ineffective. ${ }^{31}$

\section{Id. at 5 .}

24. Id. at 3. Hendley identifies a number of necessary characteristics of law that matter reciprocally. They include a general societal trust in the fairness of law, both substantively and procedurally, a remedial structure that responds to the needs of citizens, a judiciary that has sufficient power to resist legislative and executive power, and an understanding of law as "an interactive process in which both state and society participate on a more or less equal basis." Id. at 177 .

25. Id. at 3

26. Id. at 4

27. Id. at 113-14 (discussing the lethargy of the Soviet courts).

28. This point is illustrated in Hendley's article on Arbitrazh courts, which examines a Russian judicial system that is incapable of providing effective and timely enforcement of judgments. See generally Kathryn Hendley, Remaking an Institution: The Transition in Russia from State Arbitrazh to Arbitrazh Courts, 46 AM. J. COMP. L. 93, 109-18 (1998).

29. HENDLEY, supra note 22 , at $122-37$ (discussing the judicial system in the Soviet Union).

30. Id. at 167-68 (discussing the relationship between the courts and the State in the Soviet Union).

31. Id. at 167-68, 177-78. Hendley identifies ways in which Soviet law often failed to 
One can easily apply Hendley's analysis of the Soviet legal regime to legal systems in developing third-world countries, many of which may possess similar attributes. ${ }^{32}$ It also offers to inform the study of bankruptcy law, improbable as that might seem at first glance. Viewed in this context, Chapter 11 's dilution of the benefits of some rightsholders arguably moves the aggregate system of civil procedure in the United States toward the third-world model. ${ }^{33}$ The infamous delay and expense imposed by Chapter 11 provides an obvious example. ${ }^{34}$ Another example is the failure to compensate secured creditors for the delay in obtaining and applying the value of their collateral. ${ }^{35}$ But the object of the present discussion is not a critique of current bankruptcy law through the lens of procedure theory. ${ }^{36}$ Instead, the central point here is to emphasize the connection between the aggregate system of civil procedure and

make whole those who were legally wronged. For example:

Within the confines of the economic plan, factories entered into contracts with one another to supply various goods. When one party to such a contract reneged the other party was obligated under law to go to a special economic court (arbitrazh) and seek damages for the breach. Yet the money damages available were meaningless in this context. The damaged party could not obtain the needed materials elsewhere because no market existed. What the damaged party really needed was an injunction directing the party who had breached to perform. Yet arbitrazh lacked the power to order specific performance.

Id. at 33 (emphasis in original).

32. These characteristics might include a strong mistrust of substantive and procedural fairness and inadequacy of available remedies, resulting in suboptimal willingness to resort to the judicial system for relief.

33. By "aggregate system," I refer to the various state, federal, and regulatory systems of procedure in the United States as supplemented and modified by bankruptcy law, including Chapter 11 .

34. A recently published report by a committee of bankruptcy practitioners and judges provides evidence of the need to shorten the length and reduce the costs of Chapter 11 cases. See Karen M. Gebbia-Pinetti, Reporter, Select Advisory Committee on Business Reorganization (SABRE), First Report of the Select Advisory Committee on Business Reorganization, 57 BUS. LAW. 163 (2001) [hereinafter First Report]. SABRE, a special committee of the Business Bankruptcy Committee of the American Bar Association Section of Business Law, was formed "to consider the perception that Chapter 11 business reorganizations take too long and cost too much and, if appropriate, to develop legislative solutions to reduce the time and cost." Id. at 166. Apparently SABRE concluded that the length and cost of Chapter 11 cases do present problems, inasmuch as the report makes three specific legislative reform proposals. Id. at 169. There is some evidence that in recent years the situation is improving. See Douglas G. Baird \& Edward R. Morrison, Bankruptcy Decision Making, 17 J. L. ECON. \& ORG. 356, 364-65 \& n. 18 (2001) (stating that preliminary empirical evidence indicates that judges exercise well the decision of whether and when to shut down Chapter 11 debtors).

35. See infra Part IV.J (discussing the protection of undersecured creditors).

36. For that critique, see infra Part IV (addressing in detail the potential for procedure theory to inform efforts to reform bankruptcy law). 
the underlying rights provided by lawgivers under the substantive doctrine created for the benefit of rightsholders. ${ }^{37}$

Procedure theory's conceptualization of bankruptcy law as civil procedure necessarily raises a more fundamental question. Why have bankruptcy law? In other words, what value does bankruptcy law add, if anything, to the generally applicable structure of civil procedure? Douglas Baird posed this challenge several years ago, ${ }^{38}$ and I confront this challenge below by examining the means employed by bankruptcy law to achieve its end. ${ }^{39}$ But first I consider in more detail procedure theory's contemplation of the ends to which bankruptcy law should be directed.

\section{Respecting Nonbankruptcy Entitlements of Rightsholders: Procedure Theory in Context}

As explained above, procedure theory takes as its central principle that bankruptcy law should maximize the recoveries and benefits for a debtor's rightsholders, but within constraints consistent with the rationale for having a bankruptcy law. Before examining the normative basis for procedure theory, it is worth considering bankruptcy policies reflected in the Bankruptcy Code itself. In our recent article, Professor Steven Harris and I undertook this positive account and noted the enormous respect that the Bankruptcy Code generally affords legal entitlements under nonbankruptcy law. ${ }^{40}$ In particular,

37. Of course, one might draw on Hendley's critique of Soviet law to criticize more generally the operation of civil procedure law in the United States. For example, the so-called "American rule," under which the prevailing party in litigation normally must bear its own legal expenses, necessarily means that the prevailing party is not made whole (although that situation does not alone dictate that the American rule is unwarranted). See FLEMING JAMES, JR. ET AL., CIVIL PROCEDURE $§ 1.22$ (4th ed. 1992) (discussing competing policy debates concerning the American rule). As a normative theory, however, procedure theory asks primarily what it is that civil procedure generally and bankruptcy law specifically should achieve. Whether the aggregate system of civil procedure in the United States in fact is optimal in achieving its goals is a separate question, albeit an important one.

38. See Douglas G. Baird, Loss Distribution, Forum Shopping, and Bankruptcy: A Reply to Warren, 54 U. CHI. L. REv. 815, 824 (1987) [hereinafter Loss Distribution] ("The challenge facing anyone who wants to write about bankruptcy policy is to explain why a distinct bankruptcy law exists at all.").

39. See infra Part II.D (examining the methods by which bankruptcy law achieves its goals).

40. Steven L. Harris \& Charles W. Mooney, Jr., Revised Article 9 Meets the Bankruptcy Code: Policy and Impact, 9 Am. BANKr. Inst. L. REv. 85, 87-89 (2001) [hereinafter Policy] ("The Bankruptcy Code offers a blank check to the makers of non-bankruptcy law to define and delineate property law principles that will prevail in Bankruptcy."). 
we argued that Revised Article 9 of the Uniform Commercial Code is fully consistent with the policies underlying the Bankruptcy Code. ${ }^{41}$ As we acknowledged, our positive account could not answer the question whether and to what extent bankruptcy law should respect nonbankruptcy entitlements. ${ }^{42}$ Procedure theory addresses that question.

Procedure theory draws its authority and normative force from the moral foundations of the sources and substance of nonbankruptcy law. It assumes a legitimate basis for respecting the decisions of our lawgivers. And it assumes that bankruptcy law, as a part of the law of civil procedure, should not undermine these rules of law based on conflicting policy views. In short, nonbankruptcy law determines rightsholder status. Unless special treatment in bankruptcy can be justified on a basis or context peculiar to bankruptcy, ${ }^{43}$ nonbankruptcy policies announced by lawgivers necessarily are undermined if the interests of persons other than rightsholders are addressed in bankruptcy to the detriment of rightsholders. The same is true if the interests of rightsholders are diminished or enhanced at the expense or for the benefit of other rightsholders in a manner inconsistent with nonbankruptcy law. These caveats are crucial. Clearly, bankruptcy law could improve the lot of persons other than rightsholders while in no way deviating from procedure theory. But procedure theory holds that the interests of rightsholders should not be set aside or put at risk for the benefit of nonrightsholders or for the benefit of other rightsholders.

Procedure theory recognizes that bankruptcy law is not only about enforcing the rights of rightsholders against a debtor but it also addresses protection of the interests of the debtor. In the case of a corporate debtor the distinction in not significant, inasmuch as the interests of the corporate debtor can be identified by the interests of the shareholders, who are themselves

41. Id. passim (discussing Revised Article 9 of the Uniform Commercial Code). The text states:

Central to the analysis is the Bankruptcy Code's overarching respect for nonbankruptcy law's allocation of rights with respect to particular assets in which the bankruptcy debtor has an interest. Bankruptcy law gives effect to a debtor's prebankruptcy transfers of property (including security interests) and, correspondingly, to the rights of the holders of property interests that do not belong to the debtor.

Id. at 87. Of course, the fact that this attribute of the Bankruptcy Code is positive law and is generally accepted provides at least some meaningful indication of its normative value. Part IV considers some apparent exceptions to the Bankruptcy Code's respect for nonbankruptcy entitlements, including the avoiding powers.

42. Id. at n.36

43. See generally infra Part IV. A further qualification, of course, is that there must be a justification for having a bankruptcy law at all. See infra Part II.D (discussing the justifications for bankruptcy). 
rightsholders. Even in the case of an individual business debtor, the debtor is a rightsholder. Civil procedure is about a fair system of determining and dealing with legal entitlements of all concerned, and bankruptcy law fits this model.

In recognizing that nonbankruptcy law creates, defines, and shapes the contours of the legal entitlements of a debtor's rightsholders, procedure theory acknowledges the essential procedural nature of bankruptcy law. For example, nonbankruptcy law regulates competing claims to the debtor's property and orders the priorities to be afforded to those claims. Procedure theory generally rejects a bankruptcy system that would create a special reordering of rightsholders' interests in bankruptcy, whether inter se or vis-a-vis nonrightsholders. Procedural law, including bankruptcy law, should further, enhance, and vindicate, but not disrupt, policies that nonbankruptcy law creates and seeks to implement.

This overview of procedure theory must acknowledge its limitations as well. In two important respects, procedure theory presents a less sharp dichotomy than the foregoing might suggest. First, procedure theory's respect for nonbankruptcy legal entitlements is not absolute. Bankruptcy law doesand should, even under procedure theory's dictates - alter these entitlements in significant ways. Pro rata distribution among similarly situated claimants provides an example. As explained below, however, the concept of pro rata distributions conflicts with nonbankruptcy law only superficially and is fully consistent with procedure theory. ${ }^{44}$ Bankruptcy law materially alters nonbankruptcy entitlements in other respects as well. Some of these alterations are consistent with procedure theory, and some are not. ${ }^{45}$ As explained in Part IV, procedure theory recognizes that it sometimes is appropriate-and in fact feasible- to relax procedure theory's strict respect for nonbankruptcy legal entitlements and to distinguish the procedures and remedies in bankruptcy (or any other collective system for dealing with financial distress) from those applicable under nonbankruptcy procedural law. But these special bankruptcy deviations are justified under procedure theory only when the bankruptcy context is distinctive and when they further procedure theory's ends of generally respecting nonbankruptcy legal entitlements. ${ }^{46}$

44. See infra Part IV.C (discussing the concept of pro rata distributions).

45. See generally infra Part IV.

46. These bankruptcy-justified deviations from nonbankruptcy law are discussed in Part IV. In this connection it is important to be precise about what procedure theory does not claim. It does not argue that bankruptcy law always should defer to nonbankruptcy law or as some have put it, that nonbankruptcy law should "trump" bankruptcy law. If that argument were to prevail, bankruptcy law would be vacuous or, at most, interstitial. Instead, procedure theory addresses the circumstances under which bankruptcy law should or should not override otherwise applicable nonbankruptcy law. It seeks to stake out the proper domain of bankruptcy 
Second, the dichotomy between procedural law and substantive law tends to blur at the margin. Moreover, the shape and effectiveness of procedural law necessarily have profound substantive effects. Bankruptcy law's deviations from nonbankruptcy entitlements, such as pro rata sharing, undoubtedly are substantive in effect even if also characterized as a part of a generally procedural body of law. ${ }^{47}$ Furthermore, demonstrating that bankruptcy law essentially is procedural in nature does not of itself support a compelling normative theory. The procedural label may offer some illumination and a useful framework for analysis, but the label alone cannot carry the normative argument. ${ }^{48}$

Given these limitations, procedure theory faces three significant challenges. First, it must provide a convincing normative account of why bankruptcy law generally should respect, enforce, and give effect to nonbankruptcy legal entitlements. Second, it must offer a coherent account for its acceptance of a relaxation of this general principle of respect in bankruptcy in certain limited but material respects, while not rendering the general principle superfluous. Third, it must take seriously and confront claims that bankruptcy law as we know it simply is not susceptible to any overarching normative theory. ${ }^{49}$

\section{Situating Procedure Theory in the Normative Debates on Bankruptcy Philosophy and Policy}

This subpart fits procedure theory into the ongoing normative debates about bankruptcy policy. Anyone joining these debates can draw enormous assistance, as have I, from Douglas Baird's insightful article, Bankruptcy's

law. It argues that bankruptcy law should provide rules that vary nonbankruptcy law only when there is a coherent, bankruptcy-related basis for having a different rule.

47. See infra Part III.D (providing a normative account of procedure theory from the perspectives of civil procedure and federal courts). Inasmuch as bankruptcy cases reside in courts, those courts also should be empowered to adjust nonbankruptcy substantive law (state law) to the same extent that nonbankruptcy courts (state courts) are so empowered in interpreting and applying nonbankruptcy substantive law.

48. See infra Part III (making the normative case for procedure theory).

49. See David Gray Carlson, Philosophy in Bankruptcy, 85 MrCH. L. REv. 1341, 1389 (1987) [hereinafter Philosophy] ("The whole idea of finding a deep structure in a complicated, historic artifact such as the Bankruptcy Code was doomed from the start."); see also Memorandum from Charles Tabb to Chuck Mooney (June 26, 2001) (on file with Washington and Lee Law Review) ("[M]y own bias ... has evolved to the point where I have become a bit of a skeptic, or perhaps an agnostic, about normative bankruptcy theory generally."). 
Uncontested Axioms. ${ }^{50}$ In his article, Professor Baird identifies and contrasts two separate "camps" of bankruptcy experts. ${ }^{51}$ The "traditionalists" inhabit one camp, and the "proceduralists" occupy the other. ${ }^{52}$ Traditionalists typically are bankruptcy lawyers and similarly inclined academics. ${ }^{53}$ They generally are skeptical of economic models and favor more general conceptions of equity and fairness. ${ }^{54}$ Traditionalists are open to redistributional goals of bankruptcy, and believe that "preservation of firms (and therefore jobs) is an important and independent goal of bankruptcy." ${ }^{55}$ They seek to protect employment and general community interests, for example, as well as providing equity among creditors. ${ }^{56}$

Baird describes proceduralists as academics who focus (unsurprisingly) on procedure. ${ }^{57}$ Proceduralists resist redistributive goals for bankruptcy and interference with nonbankruptcy entitlements, except as may be necessary to maximize value for the holders of entitlements. ${ }^{58}$ In particular, proceduralists emphasize the instrumental role of law both outside and inside bankruptcy. ${ }^{59}$ They believe that efficient markets should permit the failure and liquidation of economically distressed firms-firms whose businesses cannot succeed because, for example, their products or services are inferior or otherwise are not desirable. In their view, bankruptcy's goal is to preserve the value of financially distressed firms (firms with sound businesses but are unable to pay their obligations). ${ }^{60}$ They prefer market solutions to financial distress over judicial discretion. ${ }^{61}$ Offering essentially an economic account of bankruptcy,

50. See Douglas G. Baird, Bankruptcy's Uncontested Axioms, 108 YALE L.J. 573, 576-79 (1998) [hereinafter Axioms] (discussing the two primary groups of bankruptcy scholars).

51. Id. at 576

52. Id. at $576-80$

53. Id. at 576 ("This group contains not only scholars firmly ensconced in the academy but also practitioners and judges who write and are active in legal reform.").

54. Id. at 592 (discussing the traditionalist view of economic and game theory).

55. Id. at 579 (discussing bankruptcy's role in rehabilitation).

56. Id. at 577. Examples of traditionalist scholars identified by Baird include Samuel L. Bufford, Karen Gross, Harvey R. Miller, Elizabeth Warren, Jay Lawrence Westbrook, and William C. Whitford. Id. at nn. 9-10.

57. Id. at 576-77 ("The group's distinctive characteristic is its focus on procedure.").

58. Id. at 577-78 (stating that bankruptcy cannot "work any special magic"). Examples of proceduralist scholars identified by Baird, in addition to himself, include Barry E. Adler, James W. Bowers, Frank Easterbrook, Thomas H. Jackson, Randal C. Picker, Robert K. Rasmussen, Robert E. Scott, George G. Triantis, and Michelle J. White. Id. at 576 n. 11.

59. Id. at 578, 589-92 (discussing law both "inside and outside bankruptcy").

60. See id. at 580-82 (contrasting "financial distress" with "economic distress").

61. See id. at 582 ("[O]ne cannot justify a bankruptcy law whose goal is to prolong the life of a bad restaurant."). 
proceduralists insist that decision-making power in bankruptcy-whether to liquidate or attempt to reorganize- - should be placed in the hands of those who stand to gain or lose. ${ }^{62}$ In the case of an insolvent debtor, that power should reside with the unsecured creditors, as shareholders and management have nothing to lose. ${ }^{63}$

Ted Janger has summed up Baird's identification of the important frontiers of the traditionalist-proceduralist divide:

According to Douglas Baird, three litmus test questions, or axioms, determine a scholar's affiliation. These questions are (1) whether the Bankruptcy Code should seek to rehabilitate firms; (2) whether bankruptcy judges should alter non-bankruptcy entitlements in order to rehabilitate firms; and (3) whether bankruptcy judges are capable of distinguishing likely candidates for reorganization from firms that are destined to fail. The paradigmatic proceduralist answers "no" to each question, while the paradigmatic traditionalist answers "yes" to all three. ${ }^{64}$

Janger dubs Baird's proceduralist answers to the first two questions, that bankruptcy law "should not favor reorganization and . . engage in post hoc reallocation of prebankruptcy entitlements," as the "proceduralist "should not. ${ }^{\prime \prime 65} \mathrm{He}$ explains that Baird and some (but not all) other proceduralists, embrace a "weak version" of the "should not" principle, recognizing that some nonbankruptcy entitlements may need to be modified in order to, and only in order to, resolve the collective action problem that is created upon insolvency. What they oppose is redistribution for its own sake, not redistribution that increases the value of the bankruptcy estate." ${ }^{16}$ Janger calls the proceduralist answer to the third question the "proceduralist 'cannot."'67 Even if judicial discretion might be justified by the weak version of the "should not," proceduralists like Baird believe that judges are incapable of identifying which firms can successfully be reorganized and which cannot. ${ }^{68}$

62. See id. at 583-86 (discussing the appropriateness of deferring to the owner-manager).

63. See id. at 586 ("[T] he new value plan leaves the greater creditor as well off as it would have been had it been allowed to seize the assets.").

64. Ted Janger, Crystals and Mud in Bankruptcy Law: Judicial Competence and Statutory Design, 43 ARIz. L. REV. 559, 566 (2001).

65. Id. at 576 .

66. Id. at $576-77$.

67. Id. at 577 .

68. Id. Accepting arguendo the weak version of the "should not," Janger's article challenges the conclusion that proceduralists draw from the "cannot"- - that bankruptcy law should employ sharp "crystalline" rules instead of fuzzy "muddy" rules. Id. at 564, 581-614. Janger does not attempt to resolve the second "should not"- that bankruptcy law generally should not be redistributive and should not disturb nonbankruptcy entitlements. Thus, his 
No doubt, Thomas Jackson's path-breaking article, Bankruptcy, NonBankruptcy Entitlements, and the Creditors' Bargain, ${ }^{69}$ marks the inception of the proceduralist academic school. The creditors' bargain theory, as further developed by both Jackson ${ }^{70}$ and Baird, ${ }^{71}$ featured a pseudo-Rawlsian contractarian core based on the idea that bankruptcy law generally reflects the hypothetical creditors' bargain that creditors would reach if they were to bargain before their extensions of credit. ${ }^{72}$ But the theory generally embraced the principles that Baird has attributed to proceduralists, including respect for nonbankruptcy entitlements in bankruptcy except as necessary to solve the collective action problem facing creditors under the first-in-time state law collection system. ${ }^{73}$ While the creditors' bargain itself never attracted widespread acceptance, ${ }^{74}$ the proceduralist principles that it embodied have been durable. ${ }^{75}$

Both the creditors' bargain theory and the proceduralist variations have drawn considerable criticism from scholars in the traditionalist camp, ${ }^{76}$ scholars

article does not confront the central tenet of procedure theory as presented here.

69. Thomas H. Jackson, Bankruptcy, Non-Bankruptcy Entitlements, and the Creditors' Bargain, 91 YALE L.J. 857 (1982). Carlson identifies the pre-beginning, of sorts, of the field as Thomas H. Jackson \& Anthony T. Kronman, Secured Financing and Priorities Among Creditors, 88 Yale L.J. 1143 (1979). David Gray Carlson, Bankruptcy Theory and the Creditors' Bargain, 61 U. CIN. L. REV. 453, 454 (1992) [hereinafter Bankruptcy Theory].

70. See generally THOMAS H. JaCKSON, THE LOGIC AND Limits OF BANKRUPTCY LAW (1986).

71. See generally Douglas G. Baird, A World Without Bankruptcy, 50 LAW \& CONTEMP. PROBS. 173 (1987).

72. JACKSON, supra note 70, at 16-17 (citing JOHN RAWLS, A THEORY OF JUSTICE 136-42 (1971)) (discussing the creditor contract theory).

73. See Axioms, supra note 50, passim. For an overview of the Baird-Jackson theory contrasting it with a traditionalist approach, see generally Loss Distribution, supra note 38.

74. Indeed, Thomas Jackson himself joined in a substantial recantation of the "simple" creditors' bargain, although I suspect that he may have done so by virtue of the intellectual tenaciousness of his co-author, Robert Scott. See generally Thomas H. Jackson \& Robert E. Scott, On the Nature of Bankruptcy: An Essay on Bankruptcy Sharing and the Creditors' Bargain, 75 VA. L. REV. 155, 189-90, 199, 202 (1989). Jackson and Scott suggested that a risk-sharing analysis derived from the "common disaster" context of admiralty law's general average contribution rule may provide a normatively justifiable explanation for various bankruptcy distributional rules under the Bankruptcy Code. Id. at 171-74. In particular, they invoked the analogy to general average contribution as an illustration that risk-sharing in bankruptcy may be an effective means to control eve of bankruptcy strategic behavior by a dominant secured creditor. $I d$. (discussing the "analogy to general average contribution").

75. See generally Axioms, supra note 50.

76. See, e.g., Warren, supra note 5, at 789-93 (disputing the use of economic analysis to limit the "distributional scheme" of bankruptcy); Rehabilitating Values, supra note 7, at 735-39 (criticizing the creditors' bargain theory). 
with an economics perspective, ${ }^{77}$ and scholars whose approaches are not easily classified. ${ }^{78}$ Procedure theory seeks to respond to and deflect much of this criticism. Procedure theory's partial response is that it is less comprehensive than other proceduralist accounts. My personal policy intuitions favor most if not all of Baird's proceduralist positions - embracing the weak "should not," to use Janger's characterization. But procedure theory as presented here stakes out a more modest scope. In his critique of Jackson's creditors' bargain theory, David Carlson challenged the very idea that anyone could discover a coherent "deep structure" in the Bankruptcy Code. ${ }^{79}$ Procedure theory proposes a much shallower structure but a normative structure nonetheless.

By proposing a baseline that generally respects nonbankruptcy legal entitlements in bankruptcy, procedure theory fully embraces the proceduralist "should not." But this feature of procedure theory is not grounded normatively on contractarian theory, as Jackson claimed the creditors' bargain to be, or on opposition to forum shopping. Indeed, its normative base is not primarily utilitarian at all, instead it draws normative support from the incoherence of any other baseline, insights drawn from bankruptcy law seen as a branch of civil procedure and federal court jurisdiction, and public choice perspectives on bankruptcy law. Procedure theory's "should not" adopts neither the "weak" nor the "strong" versions. It can coexist with welfare-enhancing redistributive rules under the weak version ${ }^{80}$ or with adaptations of the strong version, such as permitting debtors to contract for bankruptcy terms or to provide for them in corporate charters. ${ }^{81}$ Procedure theory also does not dictate the shape of

77. See, e.g., James W. Bowers, Groping and Coping in the Shadow of Murphy's Law: Bankruptcy Theory and the Elementary Economics of Failure, 88 MICH. L. REV. 2097 (1990) [hereinafter Murphy's Law] (applying Murphy's Law analysis to bankruptcy law); see also James W. Bowers, Security Interests, Creditors' Priorities and Bankruptcy 1500, in 2 ENCYCLOPEDIA OF LAW AND ECONOMICS 90 (Boudewijn Bouekaert \& Gerrit De Geest eds. 2000) (discussing the law and economics duality), available at http://allserv.rug.ac.be/ gdegeest/1500 book.pdf.

78. See generally Philosophy, supra note 49; Bankruptcy Theory, supra note 69.

79. See Philosophy, supra note 49, at 1389 ("The whole idea of finding a deep structure in a complicated, historic artifact such as the Bankruptcy Code was doomed from the start."). More recently, Carlson himself identified an "organizing principle" in bankruptcy law, which is proceduralist in large part. See David Gray Carlson, Bankruptcy's Organizing Principle, 26 FLA. ST. L. REV. 549 (1999) [hereinafter Organizing Principle] (discussing the strong-arm theory as demonstrating the organizing principle of bankruptcy). Carlson explains, from both historical and doctrinal perspectives, that the trustee's "strong-arm" power under 11 U.S.C. $\S 544(a)(1)$, under which the trustee receives the status of a hypothetical judicial lien creditor, is an important "organizing principle" that runs throughout the Bankruptcy Code. Id. at 622-23. The "strong-arm" power and other avoiding powers of the trustee are addressed in Part IV.E.

80. See supra text accompanying notes 65-68 (discussing Janger's analysis).

81. See, e.g., Barry E. Adler, Financial and Political Theories of American Corporate 
bankruptcy law except to acknowledge that bankruptcy law may be necessary to maximize the benefits for a debtor's rightsholders. ${ }^{82}$ It identifies the beneficiaries, a debtor's rightsholders under nonbankruptcy law, but does not specify the details of how value is to be preserved or grown for their benefit. Procedure theory is about who gets the pie, not about how to preserve or grow it. Consequently, it does not advocate for or against either market-based bankruptcy structures, ${ }^{83}$ generally favored by proceduralists, or those grounded in judicial discretion, favored by many traditionalists. ${ }^{84}$ This is not to say that neither approach is better than the other (one probably is) ${ }^{85}$ or that the preservation and growth of value are not important (they are, obviously), but procedure theory as advanced here does not offer an answer. ${ }^{86}$

In addition to rightsholders, bankruptcy law has other plausible beneficiaries. For example, no doubt a rehabilitated debtor firm could provide benefits to a variety of external constituencies, such as governments (more taxes), existing and future employees (continued or new employment and higher wages), and communities (wealth enhancements from increased economic activity). Procedure theory does not deny the existence or importance of these constituencies. They are without question direct social beneficiaries that a system of bankruptcy law can serve by preserving and growing value. But procedure theory holds that bankruptcy law should serve

Bankruptcy, 45 Stan. L. REv. 311, 322-23 (1993) (discussing "investor choice" and the incorporation of a "pre-established restructuring plan into [an] initial investment contract"); Janger, supra note 64, at nn. 37, 43 \& 66 (citing Susan Block-Lieb, The Logic and Limits of Contract Bankruptcy, 2001 ILL. L. REv. 503) (discussing contract bankruptcy); Robert K. Rasmussen, Debtor's Choice: A Menu Approach to Corporate Bankruptcy, 71 TEX. L. REV. 51 , 100-07 (1992) (discussing a corporations' ability to choose "no-bankruptcy" Chapter 7 filing only or create an individual bankruptcy scheme); Steven L. Schwarcz, Rethinking Freedom of Contract: A Bankruptcy Paradigm, 77 TEx. L. REv. 515, 524-34 (1999) (discussing the current debate concerning whether debtors may contract for bankruptcy terms); Alan Schwartz, Bankruptcy Contracting Reviewed, 109 Y ALE L.J. 343, 346-48 (1999) (discussing bankruptcy contracting); Alan Schwartz, A Contract Theory Approach to Business Bankruptcy, 107 YALE L.J. 1807, 1821-22 (1998)) (same).

82. See infra Part II.D (asking "Why Bankruptcy?").

83. See, e.g., Lucian Arye Bebchuk, A New Approach to Corporate Reorganizations, 101 HARV. L. REV. 775, 785-86 (1988) (proposing a new technique for reorganization). For a survey and critique of various market-based approaches, see generally David A. Skeel, Jr., Markets, Courts, and the Brave New World of Bankruptcy Theory, 1993 WIS. L. REV. 465 [hereinafter Markets].

84. See generally, Warren, supra note 5 (discussing abstract economic theory).

85. My strong intuition is that bankruptcy law should be more market based in its approach toward capturing (indeed, enhancing) value for rightsholders.

86. Procedure theory does, however, accommodate major aspects of bankruptcy law as it exists in the United States today. See infra Part IV (discussing bankruptcy law under procedure theory). 
them only collaterally; it objects to serving these interests to the detriment of the interests of rightsholders. ${ }^{87}$

\section{Why Bankruptcy?}

\section{Preserving, Increasing, and Fairly Distributing Value}

This discussion meets, at least in part, Baird's important challenge to explain why we need a bankruptcy law. ${ }^{88}$ In the context of procedure theory, if bankruptcy is civil procedure, why is civil procedure not bankruptcy? Why do we need a special body of procedural law for debtors in financial distress? Procedure theory's justification for a bankruptcy law is that specialized bankruptcy procedure can serve to maximize the recoveries of and benefits for rightsholders. If the otherwise applicable procedural law were up to the task, however, much of bankruptcy law would be unnecessary. ${ }^{89}$ The same could be said in a perfect market world in which costless contracting could settle the matters that arise in financial distress and insolvency. ${ }^{90}$ Happily, there appears to be a general consensus that a bankruptcy law (in some form) is necessary for business debtors as well as individual consumers.

The need for a bankruptcy law is most obvious in the case of a debtor in financial distress, which typically involves multiple defaults on its obligations and the present or anticipated inability to satisfy its obligations. ${ }^{91}$ A debtor in financial distress may or may not be insolvent in the sense of its obligations exceeding the value of its assets. ${ }^{92}$ There is little disagreement that one important justification for a bankruptcy law is that it facilitates the preservation,

87. See infra Part III.A (discussing the interests of rightsholders and nonrightsholders).

88. See supra note 38 (stating the need to justify bankruptcy law).

89. At least a pared down bankruptcy law would be required, however, in order to provide for an individual debtor's discharge under Chapter 7. See infra Part IV.G (discussing procedure theory's approach to the individual discharge in bankruptcy); see also Douglas G. Baird \& Robert K. Rasmussen, The End of Bankruptcy, 55 STAN. L. REV. 751, 788-89 (2002) (arguing that Chapter 11 no longer plays its "traditional" role in reorganizations of large corporations and that reorganization law no longer provides material benefits).

90. See supra note 83 (discussing contracting over bankruptcy rules).

91. Baird uses the term "financial distress" to mean a firm that is viable but that cannot satisfy its obligations. Axioms, supra note 50, at 580-81. Baird contrasts this vision of financial distress with "economic distress," intending the latter term to encompass a firm that is not viable - a firm that makes a product or provides a service that few people wish to purchase. $I d$. For present purposes, I use the term "financial distress" to encompass both scenarios (for either a firm or an individual) so long as the circumstances involve multiple defaults and the inability to timely satisfy obligations.

92. See 11 U.S.C. $§ 101(32)$ (2000) (defining "insolvent"). 
and sometimes even the increase, of value for the collective benefit of rightsholders when compared to the nonbankruptcy law's provisions for the enforcement of legal entitlements - most typically, the collection of debts. ${ }^{93} \mathrm{~A}$ single collective proceeding provides advantages over the independent efforts of rightsholders to secure their entitlements under nonbankruptcy law. For example, by calling off these uncoordinated efforts, the automatic stay imposed by Section 362 of the Bankruptcy Code allows the trustee-normally the debtor in possession in a Chapter 11 case - to identify and preserve the debtor's assets. ${ }^{94}$ Although the automatic stay obviously and materially interferes with the enforcement of nonbankruptcy entitlements of rightsholders, it is a justifiable procedural device to the extent that the end result maximizes (or at least enhances) the benefits for rightsholders. ${ }^{95}$ Even outside bankruptcy, the civil judicial enforcement of legal entitlements takes time-it is not instantaneous. Viewed in this way, one can see bankruptcy as a class action enforcement proceeding for rightsholders; it provides a single proceeding in a single court in which the affairs of the debtor and its rightsholders are sorted out. ${ }^{96}$ Resulting cost savings and efficiency gains in bankruptcy are analogous to those for which the class action has been created. ${ }^{97}$

93. See Max Radin, The Nature of Bankruptcy, 89 U. PA. L. REv. 1, 5 (1940) (discussing the essence of bankruptcy). Radin states:

The essence of bankruptcy . . . is not that the debtor's property is impounded nor that the creditors are affected, nor even that all of them are affected. Something additional is required. Unless we intend to bring the creditors into one large group, and adjust their common claims to a fund consisting of a single debtor's property, there is no reason to have recourse to bankruptcy.

Id.; see also Diane Wood Hutchinson, Class Actions: Joinder or Representational Device?, 1983 SUP. CT. REV. 459, 463 (stating that creditors' bills "were the most obvious instance of a true and necessary class action"; prior to the development of modern bankruptcy law a creditor could "sue an insolvent debtor" and, under a creditors' bill, "force a distribution of assets under supervision of the court of equity"). Those with decidedly different views on many aspects of bankruptcy law generally agree on this most basic aspect of bankruptcy law. See, e.g., GRoss, supra note 9, at 14, 137-38 (discussing the collective approach of bankruptcy); JACKSON, supra note 70, at 5, 12-14 ("Bankruptcy provides a way to make these diverse individuals act as one.").

94. 11 U.S.C. $\$ 362$ (a) (2000) (establishing the automatic stay).

95. See infra Part IV.G (discussing the automatic stay and procedure theory).

96. Actually, other courts may be involved, but for present purposes the single-court paradigm is sufficient.

97. See JaCk H. Friedenthal ET Al., Civil Procedure $\$ 16.1$, at 722 ( 1 st ed. 1985) ("The class action permits a lawsuit to be brought by or against large numbers of individuals or organizations whose interests are sufficiently related so that it is more efficient to adjudicate their rights or liabilities in a single action than in a series of individual proceedings."). 
In addition to preserving value for the benefit of rightsholders, bankruptcy law also provides a necessary procedural means for determining who is entitled to the value-for identifying the debtor's legitimate rightsholders under nonbankruptcy law. Moreover, it provides procedures for distributing the value to rightsholders, either in liquidation or under a plan of reorganization. ${ }^{98}$

To be sure, enormous disagreement exists on the answers to and the normative basis for answering questions such as why and for whose benefit is bankruptcy law positioned to preserve value. ${ }^{99}$ For example, Jackson sees bankruptcy essentially as a response to a "common pool" problem. ${ }^{100}$ Under the state law first-in-time "grab" rule, individual creditors' actions would harm the creditors as a group. ${ }^{101}$ Bankruptcy law can ensure a larger pie, on average, for creditors by preserving a firm's "going concern" value. ${ }^{102}$ As a corollary, in Jackson's view bankruptcy law generally should respect nonbankruptcy entitlements except as necessary to benefit creditors as a group. ${ }^{103}$ Unwarranted deviations from this principle would provide incentives to file bankruptcy cases in circumstances in which bankruptcy is an inappropriate response. ${ }^{104}$ On the other hand, Korobkin's Rawlsian-contractarian theory would extend the proper reach of bankruptcy to address goals of all affected interested persons, including nonrightsholders. ${ }^{105}$

98. See infra notes 246-99 and accompanying text (outlining the procedures of Chapter 7 and Chapter 11).

99. See generally supra notes 51-86 and accompanying text (discussing "proceduralist" and "traditionalist" conceptions of bankruptcy law).

100. See, e.g., JACKSON, supra note 70, at 16-17, 45 (discussing bankruptcy's role at supplementing creditor remedies in the common pool context). For a more nuanced view, see generally Susan Block-Lieb, Fishing in Muddy Waters: Clarifying the Common Pool Analogy as Applied to the Standard for Commencement of a Bankruptcy Case, 42 AM. U. L. REv. 337 (1993). law)

101. See, e.g., JACKSON, supra note 70, at 12 (discussing the "grab" rule of nonbankruptcy

102. Id. at 14. If the debtor suffers economic distress (in Baird's sense), of course, there may be no going concern value and the debtor should be allowed to fail. See Axioms, supra note 50, at 582 (stating that a "firm's capital structure ought to shape the law of corporate reorganizations"). Nonetheless, bankruptcy law may serve to preserve wealth by providing a more efficient liquidation process than is available under nonbankruptcy law.

103. See, e.g., JACKSON, supra note 70, at 33 ("Changes in non-bankruptcy rights should be made only if they benefit all those with interests in the firm as a group.").

104. See, e.g., id. at 20-27, 33 (discussing "The Destructive Effect of Changes of Relative Entitlements in Bankruptcy").

105. Infra notes 156-65 and accompanying text. Korobkin chides Jackson's contractarian creditors' bargain both for its failure to equip the bargaining creditors with the Rawlsian veil of ignorance and for its failure to include bargainers other than consensual creditors. See Contractarianism, supra note 7, at 554-65 (discussing the "Representation of Persons" and "Knowledge and Ignorance"). 
Procedure theory resolves the Jackson-Korobkin disagreement by concluding that bankruptcy law should exist to vindicate and enhance benefits for a debtor's rightsholders generally as their rights exist according to nonbankruptcy law. To this extent it lines up with Jackson and other proceduralists, but without embracing Jackson's creditors' bargain or common pool heuristics. Procedure theory embarks from the commonly accepted proposition that there is a need for a collective federal bankruptcy law designed to preserve value that justifies the existence of bankruptcy as a separate, distinct body of procedural law. ${ }^{106}$

Procedure theory does not reject the idea that the shape of bankruptcy law can, in turn, impact contents and effect of nonbankruptcy law. For example, the protections afforded an individual debtor under bankruptcy law, such as the discharge, ${ }^{107}$ may relieve nonbankruptcy law from concerns that bankruptcy law adequately addresses. ${ }^{108}$ The interactions, however, between bankruptcy law and nonbankruptcy law in no way undercut procedure theory's normative ground. Procedure theory addresses the appropriate role of bankruptcy law but does not deny that bankruptcy law has a proper domain.

In sum, procedure theory accepts the lowest common denominator of the accepted wisdom as to the need for a separate bankruptcy law. Its point of departure is the justification for a bankruptcy law on which almost everyone would agree. It then moves on to address whose interests bankruptcy law should serve and for whose benefit bankruptcy law should preserve value.

\section{Procedure Theory and the Effectiveness of Bankruptcy Law}

Procedure theory addresses the ends of bankruptcy law, enhanced benefits for rightsholders, not the specific means. As already discussed, procedure theory addresses the question whether the goals of bankruptcy should extend beyond benefiting rightsholders. ${ }^{109}$ But procedure theory makes no specific

106. If it were the case, however, that the interests of rightsholders could be served better by an approach other than a collective bankruptcy proceeding, or that bankruptcy law (or a parts of it) is unnecessary or unhelpful, procedure theory would not be offended by the elimination or modification of bankruptcy law.

107. See infra Part IV.G (discussing the individual debtor's discharge and the fresh start principle).

108. Conversely, were an individual's discharge radically limited, for example, state legislatures might feel more pressure to enact additional debtor-protective measures.

109. See supra Part I.B (discussing the focus of procedure theory). Of course, incidental benefits for nonrightsholders are fully consistent with procedure theory so long as the benefits are not at the risk or expense of rightsholders. See generally infra Part III.A. 
claims about the overall effectiveness or ineffectiveness of the provisions of the Bankruptcy Code in preserving wealth.

The particular outlines of bankruptcy law are as important as they are controversial. To the extent that current law fails to serve optimally the interests of rightsholders, procedure theory welcomes, but generally does not propose, useful reforms. For example, procedure theory does not address all aspects of the ongoing critiques and defenses of Chapter 11 reorganization. The delay and cost of Chapter 11 reorganization is a recurrent theme. ${ }^{110}$ Some scholars have questioned the very need for a regime such as Chapter 11. ${ }^{11}$ Others have stepped up with a vigorous defense. ${ }^{12}$ Still others have argued for retention of a system for reorganization with more or less radical market-based adjustments. ${ }^{13}$ Some have argued for a firm-by-firm contractually based system for reorganization of financially distressed debtors. ${ }^{114}$ The Chapter 11 debates are important and ongoing and reflect analogous debates about corporate governance. ${ }^{115}$ Baird and Rasmussen, understanding bankruptcy reorganization as a problem of corporate governance, recently explained the overriding importance of "control rights" in Chapter $11 .^{116}$ Ultimately, however, debates over bankruptcy law will be resolved, if at all, in Congress.

110. See, e.g., First Report, supra note 34, at 167-68 (outlining SABRE committee's legislative proposals to reduce the length and cost of Chapter 11 cases). Baird and Rasmussen argue that the excessive delays and costs in Chapter 11 cases have been substantially reduced during the past decade, in part because "both small and large firms can be sold as going concerns, inside of bankruptcy and out." Baird \& Rasmussen, supra note 89, at 756, 786-88.

111. See, e.g., Michael Bradley \& Michael Rosenzweig, The Untenable Case for Chapter 11, 101 YALE L.J. 1043, 1088-89 (1992) (arguing for the repeal of Chapter 11).

112. See, e.g., Lynn M. LoPucki, Strange Visions in a Strange World: A Reply to Professors Bradley and Rosenzweig, 91 MiCH. L. REV. 79, 106-10 (1992) (refuting arguments applying "perfect markets and zero transaction costs" to the bankruptcy structure).

113. See, e.g., Bebchuk, supra note 83, at 804 (explaining that a proposed type of reorganization plan fits within existing legal rules).

114. See generally supra note 81 .

115. See, e.g., Markets, supra note 83 (critiquing various proposals for reforming Chapter 11); David A. Skeel, Jr., An Evolutionary Theory of Corporate Law and Corporate Bankruptcy, 51 VAND. L. REV. 1325, 1331-50 (1998) (developing a theory of corporate law taking into account both corporate governance and corporate bankruptcy).

116. Douglas G. Baird and Robert K. Rasmussen, Control Rights, Priority Rights, and the Conceptual Foundations of Corporate Reorganizations, 87 VA. L. REV. 921, 924 (2001) ("When the managers and shareholders cannot be easily separated, control rights should lie in the hands of someone whose loyalties are aligned with the creditors, but the reorganization itself should not affect the value of the managers' equity interest."). The argument that creditor control can lead to more efficient decisions about the firm suggests a supplemental instrumental impact of procedure theory. To the extent that rightsholders, as opposed to nonrightsholders, are calling the shots in bankruptcy, better decisions are likely to be made. 
But proceduralists and traditionalists are unlikely to develop consensus views on either the basics or the specifics. ${ }^{117}$

While procedure theory may have little to advise about the effectiveness of bankruptcy law generally in preserving wealth, it must weigh in on whether bankruptcy law is faithful to the theory's tenets. ${ }^{118}$ To this end, Part IV addresses several of the principal attributes of bankruptcy law and tests them against procedure theory. Next, Part III sets up the normative case for procedure theory.

\section{The Normative Case for Procedure Theory}

This Part makes the normative case for procedure theory. The first two subparts address the two contexts in which bankruptcy law is most likely to offend procedure theory. Subpart A considers interests of rightsholders vis-avis the extraneous interests of nonrightsholders - in particular, employees and other direct and indirect beneficiaries of debtor rehabilitation, including the larger community. Subpart B takes up the interests of rightsholders inter se. Subparts C, D, and E then examine the normative bases for procedure theory, focusing on procedure theory from the perspectives of legal philosophy, civil procedure and federal court jurisdiction, and public choice analysis.

\section{A. Interests of Rightsholders Versus Interests of Nonrightsholders: Employees, Rehabilitation, and Community}

Three sets of related interests or goals have commonly been mentioned in the literature as deserving of consideration in bankruptcy, whether or not nonbankruptcy law would take account of these interests. First, proponents of a broad scope for bankruptcy law's goals point to the interests of employees. ${ }^{119}$

117. See Axioms, supra note 50, at 599 ("The fundamental difference between traditionalists and proceduralists lies in the questions they think are worth asking and the problems they think are worth studying. Bridging the gap between them has little to do with empirical research. Neither is it a task for which either traditionalists or proceduralists are wellequipped.").

118. For example, it does object to costs and delays to the extent that the effect is redistributive from rightsholders to nonrightsholders or to other rightsholders not otherwise entitled to priority. See, e.g., infra Part IV.J (discussing impact on secured creditors of delay and the inadequacy of adequate protection); Frost, supra note 4, at 123-29 (discussing redistributive impact of Chapter 11 costs and delays due to systemic pro-rehabilitation bias).

119. See, e.g., Donald R. Korobkin, Employee Interests in Bankruptcy, 4 AM. BANKR. INST. L. REV. 5, 26-34 (1996) (discussing bankruptcy law's response to employee concerns). 
Of course, to the extent that an employee has an employment contract with or is owed wages by the debtor, the employee is a rightsholder. ${ }^{120}$ Of interest here are employees who care about future employment, to which the employees presumably hold no legal entitlement. A second interest is that of the reorganization or rehabilitation of debtors. Rehabilitation, the argument goes, sometimes can be a beneficial alternative to liquidation. ${ }^{121}$ To the extent that rehabilitation would preserve, or increase, value for the benefit of rightsholders, this rehabilitation interest does not run afoul of procedure theory. ${ }^{122}$ But to the extent that the interests to be protected by the rehabilitation goal are those of nonrightsholders and liquidation - as opposed to attempting rehabilitationwould be in the interests of rightsholders, the rehabilitation goal squarely offends procedure theory. Competing interests of nonrightsholders might include those of future employment for the debtor's existing or future employees, future business opportunities for persons that wish to engage in business with the debtor or with the debtor's future employees, or governmental interests in future tax revenues from the debtor's future operations. A third interest sometimes singled out as deserving of special consideration in bankruptcy is that of "the community." ${ }^{123}$ The interests of the community are essentially the same as those served by the employee-protection and rehabilitation goals. Preserving the going business can benefit the community at large. But it is taking into account these interests at the expense of rightsholders (because, for example, rightsholders would benefit from liquidation) that contravenes procedure theory. ${ }^{124}$

Consider an example. A Chapter 11 debtor in possession wishes to close one of its three plants, sell the related assets, ${ }^{125}$ and discharge many of the employees who work at the plant. The unsecured creditors' committee supports

120. See id. at 6-11 (discussing situations in which employees would be generally unsecured creditors). An employee or former employee also might be a rights holder of a firm that owes unfunded pension obligations, for example.

121. See, e.g., Gross, supra note 9, at 98-103 (discussing the importance of rehabilitation).

122. See supra Part II.D (discussing justifications for bankruptcy law).

123. See, e.g., Gross, supra note 9, at 193-214, 228-29 (discussing "The Interests of Community").

124. This discussion assumes that it would be possible to take into account these extraneous interests in bankruptcy in an effective manner, an assumption that is questionable at best. See infra notes 333-39 and accompanying text (discussing Frost's critique of judicial redistributive policies in bankruptcy).

125. A trustee in bankruptcy may sell assets outside the ordinary course of business "after notice and a hearing." 11 U.S.C. \$363(b)(1) (2000). See 11 U.S.C. $\$ 102(1)$ (2000) (defining "after notice and a hearing"); $\$ 1107$ (a) (debtor in possession has rights, powers, and duties of a trustee, with certain exceptions). 
the closure and sale. However, some unsecured creditors, whose businesses are located near the plant, a representative of the plant's employees, and the city in which the plant is located all strongly oppose this step. Not surprisingly, the employees' objections are based not on concerns about their legal entitlements such as payment of wages but on concerns about losing their jobs were the plant to close. The objecting creditors, likewise, are objecting not out of concern for satisfaction of their prebankruptcy claims, but concern for the loss of future business with the debtor were the plant closed as proposed. And the city lodges its objection based on the potential loss of future tax revenues and the negative impact on the local economy that would arise out of the proposed closure and termination of employees. ${ }^{126}$ Assume further that applicable federal and state nonbankruptcy law either (1) places no restrictions on the debtor's closing of the plant ${ }^{127}$ and termination of the "at will" employees ${ }^{128}$ or

126. Assuming that the city is not a creditor because the debtor is current on its local taxes, the city nonetheless may be a "party in interest," a term left undefined in the Bankruptcy Code. Under 11 U.S.C. $\$ 1109$ (b), a party in interest "may raise and may appear and be heard on any issue in a case under this chapter." 11 U.S.C. $\$ 1109$ (b) (2000).

127. This assumption contemplates that the debtor in possession would not be required to give a notification under the federal Worker Adjustment and Retraining Notification Act [hereinafter WARN Act], codified at 29 U.S.C. $\$ \$ 2101-2109$ (2000). The WARN Act prohibits an "employer" from ordering a "plant closing" or "mass layoff" until after a sixty-day period following written notice to affected employees and certain government officials. 29 U.S.C. $\$ 2102$ (a) (2000). There are several reasons why the debtor in possession may be relieved from the notification requirement. For example, it may not meet the definition of "employer," or the proposed actions may not meet the definition of "plant closing" or "mass layoff." See 29 U.S.C. \$ 2101(a)(1) (2000) (defining "employer"); 29 U.S.C. \$2101(a)(2) (2000) (defining "plant closing"); 29 U.S.C. \$ 2101(a)(3) (2000) (defining "mass layoff"). Alternatively, the WARN Act also contains some exceptions to compliance with the notification requirement. See 29 U.S.C. $\$ 2102$ (b) (2000) (providing some circumstances for "reduction of notification period."). Although the assumption in the text simplifies the example, it is not essential to the analysis inasmuch as the debtor in possession could propose to comply with the WARN Act, were it applicable. See generally Laura B. Bartell, Why Warn? The Worker Adjustment and Retraining Notification Act in Bankruptcy, 18 BANKR. DEV. J. 243 (2002) (arguing that the WARN Act should be applied in all bankruptcy cases, including, contrary to Department of Labor commentary, those in which the trustee's sole function is the liquidation of a debtor's assets).

128. See 31 Am. Jur. Trials 317, 345 (1984, Supp. 2002) (discussing the "at will" employment doctrine). The text states:

At common-law, in the absence of an employment contract for a definite term, employees and employers have been free to terminate their relationship with or without cause at any time. The parties were engaged in an employment relationship said to be terminable "at will" by either party. This notion became known popularly as the "at will" doctrine .... Thus, the common law employer could discharge an employee for good cause, no cause, or even for a cause morally wrong, without thereby being guilty of a legal wrong.

Id. The doctrine has been eroded somewhat in cases of "wrongful discharge." For example, a 
(2) that the debtor complies with any applicable restrictions. Should the court consider these consequences of closure and sale, even though they have no bearing on the objectors' legal entitlements? Clearly the answer is no, subject to one caveat. Procedure theory instructs that taking into account the interests of nonrightsholders generally is not within the proper domain of bankruptcy law. ${ }^{129}$

The caveat: If maintaining the operation of the plant would be in the interests of the debtor's rightsholders generally and not to their detriment, then the judge's taking into account the extraneous interests (future employment, future business, or community) might not contravene procedure theory. ${ }^{130} \mathrm{At}$ worst, the court's consideration of those factors would be harmless error. But this caveat is probably insignificant in practice. For example, if the debtor in possession and creditors' committee supported the continued operations at a plant, why would the judge need to consider the extraneous interests beyond those of rightsholders? ${ }^{131}$

civil remedy (usually tort or contract) has been fashioned by the courts in several states for discharges that are determined to be "retaliatory," "abusive," "malicious," "in bad faith," or "in contravention of public policy." Id. at 345-48. But termination of employees by virtue of a decision to close a plant based on economic considerations, as contemplated by the example, has never been considered wrongful.

129. It is worth reemphasizing, here, that the employees and creditors are rightsholders, but the interests for which they advocate in this context- that the status quo be maintained for the plant and employees-do not arise out of their legal entitlements. They have no legal entitlements to future employment or business relationships. Obviously, the same can be said of the local government's interest in future tax revenue and the local community's interest in economic prosperity. For a recent case in which the court may have overridden the interests of rightsholders for the benefit, at least in part, of nonrightsholders, see In re LTV Steel Company, Inc., 274 B.R. 278 (2002). In $L T V$, the bankruptcy court permitted the debtor to use cash collateral that purportedly had been sold (or that was proceeds of purportedly sold collateral) under two securitization arrangements because the use "was necessary to permit Debtor to continue business operations." Id. at 281 .

130. To be clear about this caveat, it contemplates that the debtor's creditors, for example, would be made no worse off by the court's taking into account the extraneous interests. For example, if the plant sought to be closed were not profitable, the continued operation quite clearly imposes additional risks on the firm's unsecured creditors by draining value that otherwise could be used to increase their recoveries. Even if the plant were profitable, its continued use in lieu of transferring work to a more profitable plant would disadvantage unsecured creditors.

131. Alternatively, taking into account the interests of nonrightsholders arguably could be consistent with procedure theory in situations in which the effects on rightsholders of one approach or the other are identical. But, in reality, if "taking into account" the extraneous interests has any impact and if rightsholders object to relief sought by the affected nonrightsholders, then the impact presumptively must work to the detriment of rightsholders. In practice, this approach would frequently substitute a judge's decision for that of the affected rightsholders and could permit or induce judges to make difficult to overturn factual findings. See Peter A. Alces, "If You Don't Have Anything Good to Say. . . .", 15 BAnKr. Dev. J. 383, 
A closer examination of the basis for rejecting consideration of these extraneous interests that are not embodied in legal entitlements reveals a strong intuition as to the moral source of procedure theory. Consider the debtor in possession's right to close the plant and terminate the employees under applicable nonbankruptcy law. ${ }^{132}$ Properly seen, the lawgivers have not only failed to restrict the debtor's actions but have, implicitly but clearly, determined that society is improved when enterprises such as the debtor in possession retain this flexibility. If nonbankruptcy law has determined that restricting an employer's right to close a plant and discharge its employees is a bad idea for a presumably solvent firm outside bankruptcy, it must be an equally bad (or worse) idea for a presumably insolvent firm in bankruptcy. That is to say, the harm that imposing or not imposing such a restrictive policy would address is wholly agnostic concerning the financial resources and viability of employers. ${ }^{133}$ Nonbankruptcy law reflects the considered social policy as whether and to what extent firms in a market economy should or should not be forced, or induced by threat of sanctions, to do business in a particular location when they deem it undesirable. ${ }^{134}$

390 (1999), reviewing GRoss, supra note 9 ("[W]hy would we want (largely affluent and insulated) bankruptcy judges to make normative judgments they have no particular training or expertise to make, even if there were enough time and resources?"); James J. White, Failure and Forgiveness: A Review, 73 AM. BANKR L.J. 435, 441 (1999), reviewing Gross, supra note 9 ("One can foresee lawless decisions that are bound only by the judge's whim. In her proposal, Professor Gross gives the judge no principled way to decide the weight to be given to a particular community's claim.") (footnote omitted).

132. See supra note 127 and accompanying text (discussing the WARN Act).

133. Douglas Baird persuasively made a similar point several years ago:

[I]t seems odd to argue, as matter of policy, that existing management should be able to close a plant and throw workers out, but that those who lent money to the management and who come into control of the firm only because the firm failed to meet its obligations to them should not. From the perspective of the workers who are tossed out, the loss is the same in both cases.

Loss Distribution, supra note 38, at 817. If anything, one might argue (although I do not) that the insolvent firm should be cut some slack by reducing the threshold burdens of closure-just the opposite of the result that the employees' representative and the local creditors are urging on the judge in the example.

134. One might argue that a different rule in bankruptcy would have a de minimis effect on overall social policy. But that is not a principled argument to favor disparate treatment. It only holds that imposing restrictions in bankruptcy, while bad policy, would not have a significantly bad result but would have only an insignificantly bad result. 
Quite plausibly neither Congress nor the bankruptcy court ${ }^{135}$ even has the constitutional power to take into account these employee and community interests to the detriment of the debtor or the debtor's rightsholders. Thomas Plank has developed a coherent and comprehensive doctrinal theory of the limited powers of Congress and the courts under the Bankruptcy Clause of the Constitution. ${ }^{136} \mathrm{He}$ advances four principles that seek to identify and explain the dimensions of the "subject of Bankruptcies" as used in the Bankruptcy Clause. Under one of the four principles comprising Plank's Bankruptcy Clause construct, the "Non-Expropriation Principle," it is impermissible for Congress or a bankruptcy court to expropriate the rights of a debtor or its creditors for the benefit of a "Third Party." ${ }^{137}$ Rights other than those held as a debtor or a creditor are rights held by a "Third Party" under Plank's taxonomy. ${ }^{138}$ Heeding the wishes of Third Parties such as nonrightsholder employees and the city over the objections of the debtor or creditors appears to fit squarely within the proscriptions of Plank's Non-Expropriation Principle because the Third Parties in the examples seek to enhance their wealth at the expense of the debtor and the creditors. ${ }^{139}$

135. Unless noted or the context otherwise implies, references to "bankruptcy court" in this article generally encompass the federal court that happens to be exercising jurisdiction, whether that court is a bankruptcy court, a federal district court, a federal court of appeals, or the United States Supreme Court.

136. Thomas E. Plank, Bankruptcy and Federalism, 71 Fordham L. REV. 1063 (2002) [hereinafter Federalism]; U.S. CONST. art. I, $\$ 8, \mathrm{cl} .4$ (empowering Congress to establish "uniform Laws on the subject of Bankruptcies") [hereinafter Bankruptcy Clause]. See generally CHARLES JORDAN TABB, THE LAW OF BANKRUPTCY $\$ \$ 1.6,1.9$, at 32, 44-51 (1997).

137. Federalism, supra note 136, at 1091-92 n.113. The other three principles that Plank identifies are the "Debtor-Creditor Adjustment Principle," the "Non-Interference Principle," and the "Debtor-Insolvency Principle." Id. at 1089-95; see infra notes 173-74 and accompanying text (discussing the Debtor-Creditor Adjustment Principle). The Non-Interference Principle is a narrow limitation of the Non-Expropriation Principle. Federalism, supra note 136, at 1092-93. It provides that Third Parties may not use their nonbankruptcy rights, which would otherwise remain enforceable under the Non-Expropriation Principle, to prevent a debtor or creditor from initiating a bankruptcy case or otherwise obtaining the benefits of bankruptcy law, such as a termination-upon-bankruptcy clause in a contract (a so-called ipso facto clause) or a contractual waiver of the debtor's right to file a bankruptcy petition. Id. at 1092-93.

138. Id. at 1091. For example, a lessor or party to an executory contract normally wears two hats. Id. at 1113-15. If the debtor owes payment or performance under the lease or contract, the lessor or other party is a creditor. Id. But, as to the performance owed by the lessor or other party and the right to withhold performance under the lease or contract, the lessor or other party is a Third Party. Id. at 1113-15 (discussing situations where a cash seller of goods under a contract of sale is a Third Party in respect to its contingent obligation to deliver and may not be required to deliver goods to the debtor-buyer except upon tender or payment of the price).

139. As a normative theory, procedure theory does not depend on consistency with prevailing legal doctrine. But, procedure theory advises that the Bankruptcy Clause, as a part of 
It does not follow from the foregoing that procedure theory is hostile to the interests of employees or any other constituency of a debtor. Vary the example to assume that nonbankruptcy law provides substantial restrictions and consequences on a firm that wishes to close a plant. ${ }^{140}$ Now, assume that the debtor in possession and the unsecured creditors' committee argue that closure should be permitted without compliance with the nonbankruptcy restrictions and without suffering any other interference or liability under nonbankruptcy law. They argue that the compliance and consequences would hinder the prospects for reorganization and the ultimate recoveries for the debtor's rightsholders. Procedure theory dictates nonetheless that the debtor in possession is obliged to observe and suffer these restrictions and consequences. For example, the employees now are rightsholders not only to the extent of earned and unpaid wages but also as direct or indirect beneficiaries of the closure restrictions and consequences-even if not as creditors. ${ }^{141}$ Of course, the judge should take into account the interests of the debtor in possession and all rightsholders in determining whether to permit the plant to be closed, the assets to be sold, and the employees to be terminated. But the debtor should be required to observe the closure restrictions under nonbankruptcy law. ${ }^{142}$

Once again, it is plausible that neither Congress nor the bankruptcy court is constitutionally empowered to excuse the debtor from compliance with these restrictions to the detriment of the affected employees or other contemplated beneficiaries. Under this application of Plank's "Non-Expropriation Principle," bankruptcy law must not impair the rights of a "Third Party." ${ }^{143}$ Depriving the

bankruptcy law, should be interpreted and applied consistently with procedure theory. See infra notes 173-74 and accompanying text (discussing Plank's Debtor-Creditor Adjustment Principle).

140. See, e.g., WARN Act, 29 U.S.C. $\$ \$ 2101-2109$ (2000) (discussed supra note 127); N.J. STAT ANN. \& 11A:8-1 (West 2002) (requiring 45-day notice of lay off of permanent employee); WIS. STAT. ANN. $\$ 109.07$ (West 2002) (requiring 60-day notice of mass layoffs to affected employees, collective bargaining representatives, and municipalities).

141. If, for example, a debtor would be required to make additional payments to its employees arising out of a prebankruptcy noncompliance with the WARN Act, those claims should be treated as claims in the bankruptcy case under procedure theory. See Bartell, supra note 127, at 257-63 (discussing employee claims arising out of prebankruptcy noncompliance with the WARN Act).

142. It should not matter whether the employees' benefits could be enforced by private suit or only by the government. The point is that the employees should be entitled to insist that the debtor comply with the applicable nonbankruptcy law.

143. Federalism, supra note 136, at 1091-92. Note that as beneficiaries of the posited restrictions on plant closure the at-will employees are rightsholders in my taxonomy although they are Third Parties, not creditors, under Plank's terminology. Under current nonbankruptcy law and consistent with procedure theory, the debtor would be required to comply with a statute such as the WARN Act or analogous state laws. 20 C.F.R. $§ 639$ (1989) (stating that a fiduciary 
direct and indirect beneficiaries of the value of the legal restrictions on plant closure clearly would violate this principle.

Assume next that the WARN Act provides its direct and indirect beneficiaries with rights that they do not enjoy under any other law. Does delivering these benefits in any way offend procedure theory? Of course not. The WARN Act is fully consistent with procedure theory because it is generally applicable within its scope; it is not a bankruptcy-specific law. One might argue that there are bankruptcy-specific considerations that warrant excusing a firm in bankruptcy from compliance with the WARN Act. The existence of a bankruptcy-related justification for special treatment could square that treatment with procedure theory. ${ }^{144}$ For example, if the debtor is liquidating and is no longer operating a business, relief from the WARN Act might be appropriate. ${ }^{145}$ But firms liquidate outside bankruptcy as well as inside bankruptcy. Bankruptcy is not a plausible, much less appropriate, proxy for liquidation. One also might argue that firms that genuinely cannot afford to comply with the WARN Act should be excused. Perhaps bankruptcy is a somewhat better proxy for the inability to pay. But the inability to pay is not the exclusive property of firms in bankruptcy. Indeed, the WARN Act itself recognizes as much in providing for exceptions based on various types of hardship. ${ }^{146}$ For present purposes, it is sufficient to note that procedure theory recognizes circumstances in which bankruptcy-only rules are appropriate, but plant closings and mass layoffs do not appear to qualify.

Consider another example - a lawsuit on a contract in a court of general jurisdiction. Assume that the court has concluded that an enforceable contract exists, that the defendant is in breach, and that the plaintiff is entitled to a money judgment. The defendant, however, argues that enforcement of the judgment will severely damage the defendant's business prospects and force it to terminate many employees - all with disastrous effects on the local economy and the community generally. Should the court take these arguments into

whose sole function is to liquidate a failed business is not required to comply with WARN Act, implying that other fiduciaries - a debtor in possession under Chapter 11 - operating a business in bankruptcy must comply); see Bartell, supra note 127, at 278-95 (arguing that WARN Act should apply in bankruptcy with no exception for liquidations); see also 28 U.S.C. § 959(b) (2000) (providing that the trustee or receiver must manage property in its possession according to law of the state in which the property is located).

144. See supra Part II.D.1 (discussing "Preserving, Increasing, and Fairly Distributing Value").

145. See supra note 143 (providing an excuse from compliance with the WARN Act for a fiduciary that is liquidating a failed business).

146. See Bartell, supra note 127, at 250-53 (discussing exceptions from compliance with the WARN Act for faltering companies, unforeseeable circumstances, and natural disasters). 
account in exercising its discretion under equitable principles? Of course not, and the arguments are no less morally offensive when made in a bankruptcy court.

Advocates of expansive goals for bankruptcy law generally have not articulated in detail how bankruptcy law could and should take into account extraneous (nonrightsholders') interests that they favor. ${ }^{147}$ Presumably, these extraneous interests could be served by featuring into the exercise of judicial discretion, as in the plant closing example. ${ }^{148}$ They also might figure in a judge's construction and application of provisions of the Bankruptcy Code, ${ }^{149}$ or the Bankruptcy Code itself could be revised to address explicitly the role of these extraneous interests in a bankruptcy proceeding. ${ }^{150}$ But however the approach may be disguised in noble rhetoric, ${ }^{151}$ service to these extraneous interests at the expense of or risk to rightsholders is prima facie theft. ${ }^{152} \mathrm{~A}$ judicial proceeding that transfers wealth from those who are legally entitled to benefit from that value to those who hold no legal entitlement is wrong. Sympathetic as an extraneous cause-_employment," "rehabilitation," or "community"- may appear, redistribution of wealth in bankruptcy away from those who hold legal entitlements to those who do not, whether to further a

147. See, e.g., Rehabilitating Values, supra note 7, at 772 ("Bankruptcy law creates conditions for an ongoing debate in which, by expressing these conflicting and incommensurable values, participants work towards defining and redefining the fundamental aims of the enterprise. Through the medium of bankruptcy discourse, the enterprise realizes its potential as a fully dimensional personality."). Karen Gross is an exception. See Gross, supra note 9 , at 248-50 (calling for amendments to 11 U.S.C. $\$ \S 101,105,1113,1129,1225$, and 1325 to take into account the interests of "communities").

148. See Frost, supra note 4, at 123 ("[B]ankruptcy decisions are not expressly redistributive. The fact-driven nature of the process is such that most of its redistributive character derives from the judges' attitudes in making close factual calls regarding asset deployment decisions.").

149. Id.

150. See supra note 147 (noting proposals made by Gross for amending the Bankruptcy Code).

151. For example, who could be against "employment" in the abstract?

152. Cf. David Gray Carlson, Rationality, Accident, and Priority Under Article 9 of the Uniform Commercial Code, 71 MINN. L. REv. 207, 209, 245-46 (1986) (drawing analogy between theft and the first-to-file-or-perfect priority rule under UCC Article 9 that can enable a secured party acting in bad faith to achieve priority under former UCC $\$ 9-312(5)$ ); James J. White, supra note 131, at 447 ("[Gross's] proposal to take from rich creditors and give to poor creditors, despite the fact that each holds identical claims, is fundamentally an immoral attempt to take the wealth of one and give it to another simply because the former is wealthy and the latter is poor."). I consider Professor Gross's proposal in connection with the discussion of pro rata sharing in bankruptcy. See infra Part IV.C (discussing pro rata sharing). 
political agenda or a communitarian philosophy or otherwise, is a corruption of civil justice. ${ }^{153}$ Robin Hood was, after all, a crook. ${ }^{154}$

To be sure, advocates of expansive redistributive goals do not openly claim to be Robin Hood supporters. More typically, they argue that bankruptcy law should provide some redress for those whose interests are adversely affected by financial distress - with employees, rehabilitation, and community being the usual proxies- - even if those affected interests do not amount to legal entitlements. ${ }^{155}$ For example, consider the normative arguments advanced by Korobkin. Korobkin's move is to apply Rawlsian contractarianism to bankruptcy law in an attempt to discover its "deep structure."156 Unlike Jackson but faithful to Rawls, however, Korobkin places the thick "Rawlsian veil" over the hypothetical bargainers imagined to be devising the principal patterns of a bankruptcy law, and he includes in the group of hypothetical bargainers representatives of all interests that might be affected by a debtor's financial distress. ${ }^{157}$ The bargainers all know they may be affected by insolvency, but no one knows if he or she will be a debtor, an unsecured creditor (contractual or involuntary), a secured creditor, an at-will employee, a member of the community otherwise unconnected to a debtor, or the occupant

153. Could the advocates for extraneous interests be understood to be arguing that currently extraneous interests should be given legal entitlement status? That would be a stretch, inasmuch as they advocate for protecting those interests only in bankruptcy, not generally. See infra note 390 and accompanying text (discussing employment law concerns in bankruptcy). Some redistribution in bankruptcy may be justified and principled. See, e.g., infra Part IV.E (discussing trustee's avoiding powers).

154. Actually, the understanding that Robin Hood "robbed the rich and gave to the poor" was a somewhat late development in the legend's history. J.C. HOLT, ROBIN HOOD 183-86 (rev. ed. 1989).

155. See, e.g., Rehabilitating Values, supra note 7 , at 721, 761-77 (discussing the transformation of competing interests in bankruptcy); Contractarianism, supra note 7, at 546, $550-58,574$ (discussing the various concerns for preservation under bankruptcy law and the creditors bargain theory). Obviously, the mere fact that someone's interest is affected by some event or circumstance cannot plausibly support an argument that there must be some legal redress. For example, I may be enormously inconvenienced, even damaged, by traffic delays caused by a driver who carelessly failed to maintain a broken-down automobile, but no one would suggest that the driver owes a legal duty to me or the possibly thousands of other inconvenienced or damaged drivers.

156. Contractarianism, supra note 7, at 550 (stating that "bankruptcy law's deep structure" provides principles to evaluate the fairness of bankruptcy law).

157. Id. at 550, 572-89 (discussing the veil of ignorance over all affected parties, not just legal rightsholders). Korobkin ignores the fact that these affected interests could be affected in precisely the same manner by a firm's decision to close a plant absent financial distress (indeed, possibly in order to avoid financial distress) or by closing the plant based on financial distress outside bankruptcy. Stated otherwise, he does not confront procedure theory's corollary that bankruptcy law should deal only with bankruptcy-related matters. 
of any other particular relationship. ${ }^{158}$ Having consecrated and (dis)armed his inclusive hypothetical group, Korobkin argues that they would come up with something like the major features of current bankruptcy law and would seek to protect those with something to lose and who occupy the "most vulnerable position" in connection with a bankruptcy. ${ }^{159}$ But Korobkin's move seems little more than an argument that thoughtful, interested, objective, and neutral lawmakers would come to his conclusions about bankruptcy, which he claims fit "our strongly held considered judgments." 160 His "theory" turns out to be vacuous. Moreover, his conclusions generally match those of some other traditionalist scholars, consisting generally of populist ideals. ${ }^{161}$

A possible partial rescue of Korobkin's thesis might be to construe it as consistent with procedure theory as advanced here. For example, one might understand him to argue that bankruptcy law should take into account the interests of nonrightsholders only if it can do so without risk or imposition on rightsholders. ${ }^{162}$ This understanding would invoke the caveat explained

158. Id. at 574-75 ("The parties in a bankruptcy choice situation know that, once the veil of ignorance is lifted, they will occupy one or more of the positions, although they have no idea where they will end up.").

159. As Korobkin explains:

The principle of rational planning follows a similar intuition in regulating the pursuit of mutually exclusive aims of persons affected by financial distress. When it is impossible to promote one aim without frustrating the other, the principle of rational planning mandates that persons in the worst-off positions in the context of financial distress should be protected over those occupying the better-off positions. I shall refer to those positions that are worst off in financial distress as the "most vulnerable." A most vulnerable position, as I mean the term, refers to a position occupied by persons who have the worst prospects for avoiding harms in the context of financial distress. Essentially, the persons who have the worst prospects for avoiding harms in financial distress are those who, while being relatively powerless in promoting their respective aims, also have the most to lose if their aims are frustrated.

Id. at 584 .

160. Id. at 609 . Korobkin fails to note the identity of those who join him to form the "our." Most likely it refers to other traditionalists.

161. I must dissent, at least to some extent, from Baird's view that the divisions between traditionalist and proceduralist conceptions of bankruptcy do not stem from "different political beliefs." Axioms, supra note 50, at 575. The divisions may not follow the popular liberalconservative dichotomy, and to that extent I agree with Baird. But arguments about the redistribution of wealth and the advocacy of populist ideals do have political content.

162. Korobkin states:

Jackson, Baird, and others have questioned the justification for having reorganization law, based on the contention that the process is economically costly and does not inure to the financial benefit of creditors. Of course, this contention is an important one. Even if it were empirically established that reorganization does not ultimately benefit creditors, however, such a showing would not by itself 
earlier. ${ }^{163}$ Alternatively, perhaps Korobkin's conception of those in the "most vulnerable position" could conform his theory to procedure theory. ${ }^{164}$ Rescue attempts notwithstanding, Korobkin's theory most likely lies in the tradition of Robin Hood, which procedure theory rejects. ${ }^{165}$ Otherwise, it would scrupulously and consistently favor those with legal entitlements over those without, and his critique of the exclusion of these extraneous interests in bankruptcy would be rendered meaningless.

\section{B. Interests of Rightsholders Inter Se, Including Priorities}

Procedure theory generally insists that nonbankruptcy priorities be honored and respected in bankruptcy. ${ }^{166}$ Consistent with the foregoing discussion of allocating to nonrightsholders value that otherwise would benefit

require the normative conclusion that corporate reorganization must be abolished. Such a showing does not speak to the aims of many persons affected by financial distress-including employees, small business owners, and interested members of the community.

Contractarianism, supra note 7, at 597-98 (citations omitted). The understanding of Korobkin posited in the text assumes that even if reorganization law does not benefit creditors it also does not harm them. That argument is consistent with procedure theory, although superfluous.

163. See supra note 130 and accompanying text (discussing extraneous rightsholders).

164. For example, he argues that a corporation with no real chance of recovery places its employees in the worst position. Id at 587 (discussing the A.H. Robins case). However, by analogy to "medical triage," because the employees no longer have anything to lose, Korobkin would disregard their interests and consider the unsecured creditors to occupy the "most vulnerable position." Id. (Presumably, he also would ignore the interests of the shareholders, inasmuch as by focusing on the unsecureds as the "most vulnerable" he must implicitly be assuming the firm to be insolvent.) On the other hand, if the firm were insolvent but viable, presumably the employees' long-term employment interest would render them the "most vulnerable." Id. What Korobkin leaves less clear, however, is whether he would favor the employees' interests in that situation to the detriment of those with legal entitlements, such as the creditors.

165. This makes sense for Korobkin's Rawlsian theory, inasmuch as Robin Hoodism has much in common with Rawls' "difference principle." See JOHN RAWLS, A THEORY OF JUSTICE 65-73 (rev. ed. 1999) (discussing the difference principle). Under the difference principle, an initial inequality (in a two-person example) is justified only if "the difference in expectation is to the advantage of the representative man who is worse off." Id. at 68. Rawls wishes away rights and entitlements and bids the representative person behind the veil to imagine that he or she is the poorest beggar of all. If Robin Hoodism is introduced into the original position, then it can prevail.

166. This section addresses the treatment in bankruptcy of competing claims to property of a debtor's estate. Claims to priority in payment under Bankruptcy Code Section 507(a) are addressed in Part IV.I. Part IV.I also considers the "tort-first" proposals that would award priority in payment to a debtor's involuntary creditors, such as tort claimants, over other unsecured claims. 
a debtor's rightsholders, procedure theory also teaches that it is wrong for Congress to allocate assets first to rightsholders who have no legal entitlements under nonbankruptcy law, to be satisfied first from a particular item of a debtor's property, or to allocate assets first to those with junior interests in the assets to the detriment of those who have senior interests. ${ }^{167}$

Secured claims against a debtor's assets are ubiquitous and their treatment in bankruptcy has provided fodder for a substantial volume of commentary. ${ }^{168}$ Subject to relatively narrow avoidance powers and costs of delay, ${ }^{169}$ however, security interests in a debtor's personal and real property that are effective under nonbankruptcy law generally are respected as well under the Bankruptcy Code. ${ }^{170}$ This treatment corresponds to procedure theory's tenets.

Respect for nonbankruptcy priorities in bankruptcy is particularly significant in cases in which nonbankruptcy lawmakers selected priority rules because of the primarily instrumental roles of the rules, particularly in facilitating extensions of credit. ${ }^{171}$ As discussed above, ${ }^{172}$ traditionalist bankruptcy scholars, more than proceduralists, tend to "assume a bankruptcy" and then to consider what happens, or should happen, to the assets and the players involved. This approach offers the freedom to allocate value to the interests that one deems most deserving (however that might be determined). But this approach obviously ignores the instrumental role of law in shaping behavior. Presumably, the treatment that bankruptcy law affords legal

167. In general, it would be equally wrong for a bankruptcy court to exercise its discretion to adjust priorities in bankruptcy. However, given that priority rules usually emanate from statutes that generally do not welcome variance through judicial discretion, the principal locus of bankruptcy priority adjustment would be the Bankruptcy Code as enacted and amended by Congress. Of course, courts could and do effect de facto adjustments by means of the interpretation and application of statutory priority rules.

168. For collections of the commentary, see generally Steven L. Harris \& Charles W. Mooney, Jr., Measuring the Social Costs and Benefits and Identifying the Victims of Subordinating Security Interests in Bankruptcy, 82 CORNELL L. REV. 1349, 1351-55 (1997) [hereinafter Social Costs]; Steven L. Harris \& Charles W. Mooney, Jr., A Property-Based Theory of Security Interests: Taking Debtors ' Choices Seriously, 80 VA. L. REV. 2021, 202537 (1994) [hereinafter Property-Based Theory].

169. See infra Parts IV.E and IV.J (discussing avoiding powers and protection of creditors).

170. TABB, supra note 136, $\$ \$ 7.25-7.28$, at 538-55 (1997) (discussing secured claims).

171. See, e.g., Social Costs, supra note 168, at 1356-72 (examining the "social costs" of the subordinating proposals); Property-Based Theory, supra note 168, at 2028-37 (discussing whether secured credit acts to transfer wealth).

172. See supra notes 53-63 and accompanying text (comparing the views of traditionalists and proceduralists). 
entitlements in bankruptcy affects behavior of many more market participants outside bankruptcy. ${ }^{173}$

Procedure theory instructs that it is not for bankruptcy law to dull the effects of nonbankruptcy law, instrumental or otherwise. When bankruptcy law gives effect to nonbankruptcy entitlements, it enhances the instrumental effects that nonbankruptcy law may afford. ${ }^{174}$ But procedure theory is not grounded on the principle that nonbankruptcy priority rules necessarily are socially optimal. Consider another example. Assume that a nonbankruptcy law priority rule awards priority to a statutory lien in favor of an artisan over a security interest created and perfected under Article 9 of the UCC. ${ }^{175}$ Assume further a proposal to amend the Bankruptcy Code to provide that a secured claim created under Article 9 would have priority over a statutory artisan's lien, reversing the nonbankruptcy priority rule. The proposal is supported by a credible, even convincing, argument that the proposed bankruptcy priority rule would be preferable as a matter of policy to the nonbankruptcy rule. Procedure theory holds nonetheless that Congress should reject the proposed amendment.

As explained and defended in the following subpart, procedure theory generally demands respect in bankruptcy for nonbankruptcy priorities even when the nonbankruptcy rule does not reflect an optimal social policy. Whether or not bankruptcy law should adjust nonbankruptcy priorities is a question distinct from the question whether bankruptcy law should confer bankruptcy-only rightsholder status to those who do not possess nonbankruptcy legal entitlements. The case for generally not adjusting priorities in bankruptcy may be harder than the case for not allocating

173. Professor Harris and I have pointed out the flaws of a static analysis of bankruptcy distributional effects under alternative nonbankruptcy legal rules when the analysis assumes that the only differences in result would be the differences in the nonbankruptcy rules applied. See Policy, supra note 40, at 100 (discussing Revised Article 9 and reduction of perfection errors). For example, a less expansive legal regime for secured credit would not necessarily result in larger distributions to unsecured claimants than would be the case under a more expansive regime. In many situations, for example, the secured credit might not have been extended at all under the less expansive regime or a smaller amount of credit might have been extended. $I d$.

174. See, e.g., Charles W. Mooney, Jr., Insolvency Law as Credit Enhancement: Insolvency-Related Provisions of the Cape Town Convention and the Aircraft Equipment Protocol, 13 InT'L Insolvency Rev. 27, 39-42 (2004) (explaining that the Convention and Protocol could induce extensions of credit by enhancing the effectiveness in insolvency proceedings of security interests covered by those instruments, along the lines of Section 1110 of the Bankruptcy Code).

175. See, e.g., UCC $\$ 9-333$ (b) (2000) ("A [statutory or common-law] possessory lien on goods has priority over a security interest in the goods unless the lien is created by a statute that expressly provides otherwise."). 
rightsholders' wealth to nonrightsholders inasmuch as the latter case seems more intuitive. But on close examination procedure theory generally disapproves of both forms of bankruptcy-specific adjustments.

The previous subpart noted the general consistency with procedure theory of Plank's constitutional principles on the "subject of Bankruptcies" in respect of Third Party constituencies such as at-will employees and community interests. In the present context, however, of adjusting priorities in bankruptcy among rightsholders Plank's constitutional structure fails to observe procedure theory's admonitions. Under his "Debtor-Creditor Adjustment Principle," bankruptcy law generally has carte blanche to adjust the rights between a debtor and creditor, and among creditors. ${ }^{176}$ Indeed, Plank's construction of the Bankruptcy Clause would "empower Congress to abolish security interests granted by the debtor to secure the creditor's debts." ${ }^{177}$ If Plank's construction is correct as a matter of existing doctrine-if the existence of the additional constraints procedure theory would impose cannot be supported based on the history and application of the Bankruptcy Clause - this theory provides an important illustration of the value of normative theory. A powerful normative claim contrary to accepted doctrine can serve as an instrument for reforming that doctrine. ${ }^{178}$

176. Federalism, supra note 136, at 1089-91.

177. Id. at 1091. Plank does argue, however, that such a statutory move would be an unconstitutional taking in violation of the Fifth Amendment to the Constitution. Id. at n.106; see U.S. Const. amend. V ("[N]or shall private property be taken for public use, without just compensation."). Note that Plank does not advocate such a change in bankruptcy law. Id. Of course, it is not likely that Congress would enact a complete abolition of respect for security interests in bankruptcy. But in the real world both the applicable doctrine and its normative underpinnings provide important insight to lawmakers. Moreover, legislation introduced in 2002 would have made a huge range of routine secured transactions avoidable in bankruptcy (although the bill's sponsors probably did not intend such a broad scope). Employee Abuse Prevention Act of 2002, S. 2798, 107th Cong. (2002); Employee Abuse Prevention Act of 2002, H.R. 5221, 107th Cong. (2002). For a discussion of this legislation, see generally William M. Burke et al., Report on Avoidance, Subordination, Super Priority, and Recharacterization Provisions of the Proposed Employee Abuse Prevention Act of 2002 (Sept. 3, 2002) (on file with Washington and Lee Law Review); Steven L. Harris \& Charles W. Mooney, Jr., The Unfortunate Life and Merciful Death of the Avoidance Powers under Section 103 of the Durbin-Delahunt Bill: What Were They Thinking?, 25 CARDOZO L. REV. 1829 (2004).

178. I argue below that the (nearly) unfettered deference of Plank's Debtor-Creditor Adjustment principle should be reined in by an interpretation of the Bankruptcy Clause more consistent with procedure theory. See infra notes 219-20 and accompanying text (discussing consistency in procedure theory). 


\section{The Philosophical and Jurisprudential Account of Procedure Theory}

The foregoing discussion explained that procedure theory calls on bankruptcy law to respect, observe, and enforce legal entitlements arising in nonbankruptcy law. ${ }^{179}$ The first two subparts of this Part identified the settings in which prima facie and intuitive wrongs would arise from a bankruptcy regime that would redistribute the wealth of rightsholders to nonrightsholders or reorder nonbankruptcy priorities. ${ }^{180}$ But procedure theory does not insist or assume that nonbankruptcy law necessarily is in all respects just and optimal, however those attributes might be measured or evaluated. So why is drawing an overarching normative baseline to respect nonbankruptcy legal entitlements a morally superior move? Why should the makers of bankruptcy law not correct and override perceived deficiencies in nonbankruptcy law? Procedure theory must confront these questions directly. This subpart and the following two subparts address these questions.

A conventional jurisprudential approach might first confront the source of law's validity, its relationship to accepted social customs and morals, and the basis for recognizing legal obligations. A plethora of theories have addressed these questions, including interpretive theories ${ }^{181}$ and theories such as positivism, ${ }^{182}$ natural law, ${ }^{183}$ and legal realism. ${ }^{184}$ Procedure theory generally is agnostic as to the application of these theories to nonbankruptcy law. However, procedure theory does assume the legitimacy of the body of nonbankruptcy law for which it dictates respect. ${ }^{185}$ Stated otherwise, if legitimate nonbankruptcy law should be observed and enforced outside bankruptcy, procedure theory insists that it should be observed and enforced inside bankruptcy, absent some

179. See supra Part II.B (discussing the ends and principles of procedure theory of bankruptcy law).

180. See supra Part III.A-B (discussing the interest of rightsholders and nonrightsholders).

181. See generally RONALD DWORKIN, LAW'S EMPIRE (1986).

182. See generally H.L.A. HART, THE CONCEPT OF LAW (1961); JosePH RAz, THE AUTHORITY OF LAW (1979).

183. See generally JOHn FinNis, NATURAL LAW AND NATURAL Rights (1980).

184. See generally Michael MARTIN, LEgal REAlism: AMERICAN AND SCANDANAVIAN (1997).

185. Here I share the majority view in contemporary jurisprudence of law's intrinsic claim of legitimacy. See, e.g., Joseph Raz, Hart on Moral Rights and Legal Duties, 4 OXForD J. LEGAL STUD. 123, 131 (1984) ("No system is a system of law unless it includes a claim of legitimacy."). But there is a minority that questions law's intrinsic claim for respect. See generally Kenneth Einar Himma, Law's Claim of Legitimate Authority, in HART's POSTSCRIPT 271, 309 (Jules Coleman ed., 2001). To be precise, procedure theory does not claim that nonbankruptcy law has greater legitimacy than bankruptcy law or that any deviation from procedure theory by bankruptcy law renders bankruptcy law illegitimate. 
bankruptcy-specific justification. ${ }^{186}$ It follows that procedure theory accepts that nonbankruptcy law reflects a wide range of normative justifications as well as inconsistencies and flaws. While procedure theory does not shy from beneficial reforms of nonbankruptcy law, it denies the coherence and rationality of implementing these reforms through bankruptcy law alone.

Consider again the example of a nonbankruptcy legal rule that awards priority to a statutory or common-law possessory lien over an Article 9 security interest, discussed in Part III.B. Assume that this nonbankruptcy law priority rule is demonstrably suboptimal because a different rule would increase economic efficiency, would further distributive justice, or would increase social welfare based on any other rationale. ${ }^{187}$ Under this assumption it follows that altering (reforming) the priority rule in bankruptcy would provide a net benefit in social welfare, albeit to a lesser extent than an across-the-board reform of the priority rule, a reform applicable both inside and outside bankruptcy. Yet procedure theory's normative position would not condone this admittedly welfare-enhancing utilitarian move through changes in the bankruptcy laws.

Procedure theory rejects the bankruptcy-grounded utilitarian reform as incoherent, even if welfare-enhancing in the specific case. Consider, for example, Ronald Dworkin's framework. The bankruptcy-only priority reform would offend Dworkin's independent virtue of law's "integrity." 188 In particular, the reform would succumb to Dworkin's integrity-based condemnation of "checkerboard" laws. ${ }^{189}$ Dworkin posits an example of a society sharply divided on the morality of abortion. This division gives rise to a "Solomonic" law that would criminalize abortion "for pregnant women who

186. Consistent with the assumption that nonbankruptcy law is legitimate, were an aspect of nonbankruptcy law shown to be illegitimate, procedure theory would not be offended by that showing inasmuch as that aspect would not be "law" as contemplated by procedure theory. Critics of the proposition that bankruptcy law should respect nonbankruptcy entitlements generally have not based their criticisms on the illegitimacy of the nonbankruptcy entitlements - the entitlements should not be honored even outside bankruptcy. See infra Part IV (discussing the circumstances in which procedure theory does support some deviations from nonbankruptcy law in bankruptcy, based on bankruptcy-specific justifications).

187. For present analytical purposes, there is nothing special about the posited priority rule. The example just as well could be a suboptimal nonbankruptcy legal rule that failed to acknowledge the interests of at-will employees or the community more generally, as discussed in Part III.A. Of course, the proposition that one rule or the other enhances social welfare is impossible to prove or know with certainty.

188. See DWORKIN, supra note 181, at 176-217 (discussing the legislative principle of political integrity which requires legislators to adopt a set of laws that are morally coherent).

189. Id. at 182 ("[M] any of us, to different degrees in different situations, would reject the checkerboard solution not only in general and in advance, but even in particular cases if it were available as a possibility."). 
were born in even years but not for those born in odd ones." ${ }^{190}$ As a compromise, this statutory technique would please opponents of abortion rights more than no ban at all while pleasing proponents of reproductive freedom more than a complete ban. Arguing that neither concerns for justice nor fairness would condemn this checkerboard law, Dworkin nonetheless concludes that a state would violate the principle of integrity by enacting this "unprincipled" rule of law. ${ }^{191}$

Denise Reaume has advanced a trenchant critique of Dworkin's integrity theory and analysis. ${ }^{192}$ She argues convincingly that integrity is not a standalone, independent value. ${ }^{193}$ She agreed, however, that Dworkin's checkerboard examples should be condemned, but on grounds of fairness and justice instead of integrity, noting that "Dworkin has deliberately chosen examples involving irrational criteria." ${ }^{194}$ Whether based on Dworkin's

190. Id. at 178. Dworkin also mentions other possible checkerboard laws that he claims violate the integrity principle. One example imposes strict liability on automobile manufacturers but not on washing machine manufacturers, and another forbids racial discrimination on buses but allows it in restaurants. Id.

191. Id. at 183-84 (stating that accepting a checkerboard solution demonstrates the inconsistent principles which offend integrity). Dworkin states:

The most natural explanation of why we oppose checkerboard statutes appeals to that ideal [of integrity]: we say that a state that adopts these internal compromises is acting in an unprincipled way, even though no single official who voted for or enforces the compromise has done anything which, judging his individual actions by the ordinary standards of personal morality, he ought not to have done. The state lacks integrity because it must endorse principles to justify part of what it has done that it must reject to justify the rest.

Id. Dworkin's example could be adjusted to contemplate the federal system of government that exists in the United States. A federal law might criminalize abortion in half of the states and provide that abortion is available with no constraints in the other half. To ensure that the adjusted example strikes a parallel comparison with Dworkin's, the law would prohibit travel from one state to another in order to obtain an abortion, and the prohibition would be strictly and effectively enforced. As with Dworkin's original example, the checkerboard state of affairs under the posited law would be incoherent and would fail Dworkin's integrity test.

192. See Denise Reaume, Is Integrity a Virtue? Dworkin's Theory of Legal Obligation, 39 U. TORONTO L.J. 380 (1989) (critiquing Dworkin's integrity theory).

193. Id. at 400 ("These arguments lead to the conclusion that integrity is not a value independent of justice or fairness.").

194. Id. at 398. Reaume states:

[T] he chequer-board outcome denies some-either fetuses or women-what they are entitled to, and is therefore wrong. Again, this is the logical result of the fact that principles are general standards .... Chequer-board solutions are never proposed, and therefore are not commonly debated, because to do so would be to demonstrate bad faith. One's commitment to one's proclaimed principle would be called into doubt. Integrity, conceived of as independent of justice, is not needed to explain this. It takes us no further to argue that it is integrity which requires the adoption of 
integrity heuristic or Reaume's fairness-justice critique, irrational and unprincipled checkerboard laws should be eschewed.

The bankruptcy-only priority rule posited in the example would be just such an irrational, unprincipled checkerboard statute. The example posits that nonbankruptcy law has awarded priority to certain possessory liens over those of Article 9 security interests in the context of competing claims to a debtor's property. The factors that rationally might be considered for the posited rule are the same whether applied in a priority contest that takes place inside or outside of bankruptcy. The debtor's assets are scarce. ${ }^{195}$ Whether the priority rule is applied inside or outside bankruptcy, there is no coherent basis for different outcomes. If Congress wishes to implement the desirable, welfareenhancing reform embodied in a revised priority rule, it should do so generally without regard for whether bankruptcy is involved. ${ }^{196}$ To apply the revised rule only in bankruptcy is no more rational than applying it only in odd years. A bankruptcy-only fix would be incoherent. ${ }^{197}$

Procedure theory's call for respecting nonbankruptcy entitlements in bankruptcy and its corresponding recognition of the incoherence of entitlement adjustments in bankruptcy (but not outside bankruptcy) is not new. For example, these principles are a central feature of the Baird and Jackson creditors' bargain theory. ${ }^{198}$ But unlike the creditors' bargain thesis, procedure

principles. This is already achieved by a requirement to pursue justice. Id. at 397.

195. Otherwise, the priority rule would be of no particular moment. But I do not assume for this purpose that a priority rule is valuable only if the debtor is insolvent. See infra note 207 and accompanying text (discussing priority rules).

196. That Congress might not have the power to adopt an across-the-board priority rule, however, does not weaken this argument. See infra notes 210-13 and accompanying text (discussing the Commerce Clause and the Bankruptcy Clause).

197. Procedure theory draws on Dworkin's integrity/coherence critique and Reaume's fairness/justice critique of checkerboard laws as independent normative support for the results that procedure theory demands. As Dworkin's abortion law example indicates, however, the normative purchase of these critiques is not limited to the context of the bankruptcy/nonbankruptcy dichotomy. It also would be incoherent for a nonbankruptcy law to provide special priority rules that would apply only in the case of priority contests involving insolvent debtors. See infra note 207 and accompanying text (discussing priority rules).

198. Supra notes 102-03 and accompanying text. Baird states that:

A coherent approach to the question of how losses from failed firms should be distributed cannot ignore the distributional effects many legal rules have on firms that are not in bankruptcy. Legal rights should turn as little as possible on the forum in which one person or another seeks to vindicate them. Whenever we must have a legal rule to distribute losses in bankruptcy, we must also have a legal rule that distributes the same loss outside of bankruptcy. All Jackson and I advocate is that these two rules be the same. 
theory makes no utilitarian claim that its respect for nonbankruptcy entitlements in bankruptcy necessarily enhances social welfare. ${ }^{199}$ It is not subject to Carlson's critique of Baird and Jackson's "bankruptcy neutrality" forumshopping thesis. ${ }^{200}$ Unlike the creditors' bargain analysis, procedure theory is not grounded on the reduction of inefficient forum shopping through eliminating perverse incentives created by inconsistencies in bankruptcy and nonbankruptcy law. ${ }^{201}$ Procedure theory does not claim that "bad" results necessarily result from its violation or that nonbankruptcy law is optimal. ${ }^{202}$

Could the posited bankruptcy-only priority rule be rationalized if it were instead an "insolvency-only" rule - one that would apply both outside and inside bankruptcy but only when the debtor is insolvent? ${ }^{203}$ I believe not, because there is no rational basis for a priority rule that applies only in the case of insolvency. In some situations nonbankruptcy law does take account of a

Loss Distribution, supra note 38, at 822 (footnote omitted).

199. Procedure theory's tenets may be welfare-enhancing when its application in the aggregate is considered, just as civil procedure generally enhances welfare to the extent that it provides an efficient and fair system of vindicating legal entitlements. See, e.g., supra notes 2237 and accompanying text (discussing Hendley's study of substantive and procedural law in the former Soviet Union). Moreover, putting the interests of rightsholders first and giving particular weight to the views of the residual owners of a firm, generally the unsecured creditors when the debtor is insolvent, may encourage wealth-enhancing decisions. But these possibilities-probabilities I would argue-differ from a claim that the vindication of legal entitlements called for by procedure theory necessarily enhances welfare.

200. See, e.g., Philosophy, supra note 49, at 1377--82 (critiquing Jackson's bankruptcy neutrality argument); Bankruptcy Theory, supra note 69, at 466-69 (discussing bankruptcy neutrality).

201. See Bankruptcy Theory, supra note 69, at 466-69 (criticizing the creditors' bargain inefficient forum shopping thesis). Jackson's forum-shopping argument is grounded on the notion that disparities between treatment inside and outside bankruptcy will lead to the use of bankruptcy law in inappropriate circumstances, when it's not necessary to solve the collective action, common-pool problem. See, e.g., JACKSON, supra note 70, at 21-27, 57-62, 153, 193 (discussing the problem of relative entitlements). Carlson asserts other complaints against bankruptcy neutrality as well. Philosophy, supra note 49, at 1342 n.4 ("Bankruptcy neutrality" is Carlson's term for Jackson's position). Given Jackson's utilitarianism, Carlson's critique of Jackson's bankruptcy neutrality adopts a utilitarian perspective. For example, Carlson argued that neutrality "freezes" a bankruptcy judge from otherwise needed action to "overrule state law's bad influence by molding a federal rule in a bankruptcy proceeding." Id. at 1381. Carlson also asserts that state legislatures sometimes lack the power to make meaningful reforms. Id. This critique suggests that if utilitarianism is the goal, the bankruptcy judge should not need to wait on the state legislatures to act. Because procedure theory is not a utilitarian theory, its bankruptcy neutrality (subject, of course, to exceptions) does not succumb to Carlson's utilitarian critique of Jackson's utilitarian theory.

202. Thus, it does not derive the "ought" from the "is."

203. If so, then one might justify a bankruptcy-only priority rule by arguing that bankruptcy serves as a rough proxy for insolvency. 
debtor's insolvency. For example, certain transfers can be set aside under state fraudulent transfer law when made by an insolvent transferor. ${ }^{204}$ But that is because the other creditors would be disadvantaged for the benefit of the transferee should the transfer stand. ${ }^{205}$ There is no analogous basis for applying the posited priority rule only in the case of insolvent debtors. Priority rules can have meaning and add value whether or not a debtor is insolvent. ${ }^{206}$ For example, the claimant that is advantaged by a priority rule applicable to particular property of a debtor need not look to the debtor's other assets that would be reachable only through judicial process, even if the debtor is solvent.

Another possible justification of a bankruptcy-only priority rule would recognize that, under the appropriate circumstances, Congress might achieve a de facto generally applicable priority rule by enacting a bankruptcy-only rule. For example, a priority rule that materially weakened secured claims in bankruptcy would have an instrumental effect on the availability and price of secured credit generally, inasmuch as extenders of credit would take into account the effect of the rule at the time credit is extended or refused. ${ }^{207}$ Could such a bankruptcy-specific priority rule be defended from procedure theory's condemnation? Clearly not, for several reasons. First, even the adoption of such a secured-claim-weakening bankruptcy rule would not mean priority contests outside bankruptcy would no longer occur. Consequently, the rule actually would not work the same as a generally applicable rule, even though some effects would be similar. Second, in general most bankruptcy-only priority rules are not likely to have such an enormous impact outside bankruptcy. Consider the proposed bankruptcy-only priority rule posited in the example - awarding priority to perfected consensual security interests over statutory artisan's liens. Reported decisions relating to priority contests

204. See, e.g., UNIF. FraUdULENT TRANSFER ACT \$ 5(a), 7A U.L.A. 330 (1999) [hereinafter U.F.T.A.] (stating that a transfer made while transferor is insolvent is avoidable if transferor does not receive reasonably equivalent value).

205. The avoidance of fraudulent transfers and procedure theory are discussed in Part IV.E.3.

206. Moreover, determining whether a debtor is insolvent at any particular point in time can be difficult. See, e.g., Susan Block-Lieb, Why Creditors File So Few Involuntary Petitions and Why the Number is Not Too Small, 57 BROOK. L. REV. 803, 803-04 (1991) (stating that Congress adopted the standard of general failure to pay debts as they come due for involuntary bankruptcy petitions because the former Bankruptcy Act's standard was too burdensome on petitioning creditors).

207. Social Costs, supra note 168, at 1356-64 ("One major benefit is the facilitation of credit that creditors otherwise would not extend."). In addition, bargaining among creditors and a debtor would take into account the bankruptcy-only priority rule and could impact a debtor's decision to file or not to file. This possibility, of course, is the Baird and Jackson forumshopping paradigm. See supra note 199 (discussing forum-shopping). 
between statutory or common-law liens and consensual security interests strongly support both the first and second points. These priority contests have occurred (at least, according to the reported decisions) overwhelmingly outside bankruptcy. ${ }^{208}$

Third, if legislating a generally applicable priority rule were the goal of Congress, why would it codify the rule as part of the Bankruptcy Code? One obvious reason is that Congress might not have the power to enact a generally applicable rule, leaving the Bankruptcy Clause as its avenue of last resort. But justifying a (purported) de facto generally applicable rule in this way would pervert the Bankruptcy Clause. ${ }^{209}$ Finally, enacting a bankruptcy-only rule also probably would reflect a second-best strategy supported by those who might favor a generally applicable rule but whose influence and power is limited to the field of bankruptcy law. ${ }^{210}$

Consider further the posited priority rule, assumed to be a desirable reform that rationally should be made across-the-board. If Congress otherwise lacks the constitutional power to enact across-the-board reform, ${ }^{211}$ the Bankruptcy Clause should not be interpreted to confer that power on Congress. Inasmuch as the reform is assumed not to be rationally limited to bankruptcy cases, it would be incoherent to empower its enactment under the Bankruptcy Clause. ${ }^{212}$

208. The July 2003 UCCSEARCH CD included 176 digested decisions indexed under Former Uniform Commercial Code (U.C.C.) Section 9-310. Former Section 9-310 contained a priority rule relating to liens arising by operation of law in favor of suppliers of services or materials. Of these decisions, 142 (more than $75 \%$ ) were decided outside bankruptcy. There were 33 cases that were decided in bankruptcy. Two others were decided outside bankruptcy, but the relevant debtors had filed for bankruptcy. One case was impossible to classify.

209. See infra notes 211-18 and accompanying text (discussing the priority rule).

210. I develop this theme in Part III.E, which addresses the public choice account of procedure theory.

211. The power of Congress in this respect is beyond the scope of this article. I, however, note that the Supreme Court has sometimes taken a narrower view of the powers of Congress and the courts in recent years. See, e.g., United States v. Lopez, 514 U.S. 549, 567-68 (1995) (stating that Congress may not have the authority under the commerce clause to ban weapons from school zones).

212. The Supreme Court has expansively interpreted what lies within "the subject of bankruptcies" under the Bankruptcy Clause. See, e.g., Wright v. Union Cent. Life Ins. Co., 304 U.S. 502, 513 (1938) (stating that a bankruptcy law extending the period for redemption by debtor of property subject to a mortgage is valid and not unconstitutional under the Bankruptcy Clause). The relevant normative claim, here, is that procedure theory dictates that the Bankruptcy Clause, as an element of bankruptcy law, should be interpreted so as to confine the power of Congress and the courts to serving the goals of bankruptcy that procedure theory identifies. There is no plausible or coherent basis for the Bankruptcy Clause to extend the power of Congress and the federal courts beyond those necessary to implement the goals of bankruptcy. 
The incoherence of bankruptcy-only rules in neutral settings also reflects the incoherence of some traditionalist accounts of bankruptcy policy. If nonbankruptcy legal entitlements do not provide the baseline in bankruptcy (subject to coherent relaxation, as contemplated by procedure theory), ${ }^{213}$ what baseline would be preferable? Presumably, bankruptcy-only distributional rules could be justified on any conceivable normative grounds ranging from economic efficiency to communitarian values to any other theory of welfare or justice. Limited only by the stricture of legislating for bankruptcy cases alone, bankruptcy policy would amount to no more than "do good" as Congress might view "good" from time to time in a given context. That unbounded approach does not offer any theory of bankruptcy whatsoever.

Plank's theory of the Bankruptcy Clause and its proper limits rejects such an open-ended approach to the treatment of Third Parties under the NonExpropriation Principle (as moderated by the Non-Interference Principle). ${ }^{214}$ But Plank's Debtor-Creditor Adjustment Principle in large part would embrace this unbounded scope of the Bankruptcy Clause. That principle would allow Congress and bankruptcy courts a free rein, constitutionally, to adjust the relationships between and among a debtor and its creditors. ${ }^{215}$ As a constitutional matter, it would easily welcome the proposed priority rule discussed in the example. Presumably, bankruptcy law could adopt Robin Hood's credo for these relationships, subject only to constitutional restrictions on takings. ${ }^{216}$

Procedure theory's normative claim offers a narrower, more purposive framework for interpreting the Bankruptcy Clause. It recognizes that the core principle of bankruptcy law is the enhancement and vindication of legal entitlements in a collective proceeding. Deviations from the strict respect for nonbankruptcy entitlements are acceptable only if reasonably calculated to serve this core principle. ${ }^{217}$

213. See infra Part IV (discussing bankruptcy law under procedure theory).

214. See supra notes 136-39 and accompanying text (discussing Plank's theory of the Bankruptcy Clause).

215. See supra notes 176-78 and accompanying text (discussing bankruptcy law's ability to adjust creditor rights). As already noted, Plank does recognize that the Bankruptcy Clause is limited by the Fifth Amendment in this context. See supra note 177 and accompanying text (discussing bankruptcy law's ability to adjust creditor rights).

216. See supra note 177 and accompanying text (discussing bankruptcy law's ability to adjust creditor rights).

217. Part II.D developed this core principle. 


\section{The Procedural and Federal Court Jurisdiction Account of Procedure Theory}

As the caption of this subpart may appear circular, it is worth a few words to identify its goals and strategy. I continue to use the term "procedure theory" to mean the normative theory of bankruptcy presented in this Article, not to a more general theory of civil procedure. This subpart first considers the structure, vocabulary, and function of bankruptcy law and argues that it mirrors much of more generally applicable, or "trans-substantive," civil procedure law. I then explain that the history of both bankruptcy law and federal court jurisdiction supports the characterization of bankruptcy law as a branch of civil procedure law. Finally, I move on from the positive account of bankruptcy law to draw on the goals of procedural law to support the normative component of the procedure theory of bankruptcy. From that perspective I argue that bankruptcy law should serve nonbankruptcy legal entitlements and generally should reject redistributive ends that contravene those entitlements. In particular, procedure theory draws support from the normative underpinnings of Erie Railroad Company v. Tompkins. ${ }^{218}$ An analysis of the similar origins of the Bankruptcy Clause and federal diversity jurisdiction, supported by the lessons of Erie, teach that the applicable rules of substantive law should not be varied based on the identity of the forum of application.

Bankruptcy law in the United States consists of Title 11 of the United States Code (the Bankruptcy Code), several provisions of Title 18 (Crimes and Criminal Procedure) ${ }^{219}$ and Title 28 (the Judicial Code), ${ }^{220}$ the Federal Rules of Bankruptcy Procedure, ${ }^{221}$ the Official Bankruptcy Forms, ${ }^{222}$ and local rules of federal district courts and bankruptcy courts ${ }^{223}$ - supplemented, of course, with judicial decisions. ${ }^{224}$ Consistent with its procedural focus, the Bankruptcy Code is structured around a judicial proceeding called a bankruptcy "case" filed

218. Erie R.R. Co. v. Tompkins, 304 U.S. 64 (1938).

219. 18 U.S.C. $\$ \$ 151-57$ (2000) (providing criminal code associated with bankruptcy).

220. See, e.g., 28 U.S.C. $\$ 1334$ (2000) (establishing jurisdiction of bankruptcy cases and proceedings); 28 U.S.C. $\$ 1408$ (2000) (establishing venue of bankruptcy cases); 28 U.S.C. $\S 1409$ (2000) (establishing venue of proceedings under, arising in, or related to bankruptcy cases).

221. FED. R. BANKR. P.

222. OFF. BANKR. FORMS

223. See TABB, supra note $136, \S 1.13$, at 57 (stating that local court rules are an important part of bankruptcy practice).

224. Substantive state law also plays a crucial role in bankruptcy cases and proceedings. See id. $\$ 1.14$, at 57-60 ("The substantive law applied in bankruptcy cases . . is in the greater part governed by state law."). 
in a "bankruptcy court."225 Many other aspects of bankruptcy law and its terminology also hark of its procedural features. A bankruptcy case is commenced by the filing of a "petition" with the bankruptcy court. ${ }^{226}$ A bankruptcy petition may be either "voluntary," filed by a "debtor," "joint," filed by a "debtor" and the debtor's "spouse," or "involuntary," filed by one or more holders of "claims" against the debtor. ${ }^{227}$ The filing of a voluntary or joint petition "constitutes an order for relief" under the "chapter" under which the petition was filed. ${ }^{228}$ If an involuntary petition is filed, the debtor is entitled to file an "answer." 229 If the involuntary "petition is not timely controverted," the court "shall order relief against the debtor."230 If the debtor's answer does controvert the involuntary petition, then the court must order relief only "after trial" and if at the trial one of two statutory grounds for relief are shown, one of which is that "the debtor is generally not paying such debtor's debts as such debts become due unless such debts are the subject of a bona fide dispute."231

There is a bankruptcy court consisting of "bankruptcy judges" in each federal district. ${ }^{232}$ The United States Court of Appeal in the circuit in which the relevant bankruptcy court is located appoints the bankruptcy judges to fourteenyear terms. ${ }^{233}$ The powers of the bankruptcy courts and bankruptcy judges derive from Article I and the Bankruptcy Clause of the Constitution, as provided by Congress. ${ }^{234}$ The district courts have "original" jurisdiction of cases under the Bankruptcy Code, but the jurisdiction is not exclusive as to "civil proceedings arising under" the Bankruptcy Code "or arising in or related to cases" thereunder. ${ }^{235}$ Each district court determines the bankruptcy cases and "proceedings" under the Bankruptcy Code to be heard by the bankruptcy courts

225. See 11 U.S.C. $\$ 301$ (2000) (defining voluntary cases); 11 U.S.C. § 302(a) (2000) (defining joint cases); 11 U.S.C. $\$ 303$ (2000) (defining involuntary cases). In addition, the Bankruptcy Code also makes provision for cases ancillary to foreign proceedings, which also are commenced by the filing of a petition. 11 U.S.C. $\$ 304$ (a) (2000).

226. Id

227. Id

228. 11 U.S.C. $\$ \S 301,302$ (a) (2000).

229. Id. $\S 303(\mathrm{~d})$.

230. Id. $\S 303(\mathrm{~h})$.

231. Id. $\S 303(\mathrm{~h})(1)$. The other ground is that a "custodian" has been appointed for the debtor's property outside of the Bankruptcy Code. "Custodian" is defined to include nonbankruptcy receivers and trustees over property of the debtor and assignees for the benefit of the debtor's creditors. 11 U.S.C. $\$ 101(11)(2000)$.

232. See 28 U.S.C. $\$ 151$ (2000) (designating bankruptcy courts).

233. See 28 U.S.C. $\$ 152$ (2000) (governing "appointment of bankruptcy judges").

234. See 28 U.S.C. $\$ 157$ (2000) (outlining bankruptcy procedures).

235. 28 U.S.C. $\$ 1334(\mathrm{a}-\mathrm{b})(2000)$. 
in that district. ${ }^{236}$ When a bankruptcy court hears a proceeding under the Bankruptcy Code other than a "core proceeding," absent consent of the parties the bankruptcy court must submit proposed findings of fact and conclusions of law to the district court, which reviews de novo any matters to which a party has objected. ${ }^{237}$ The district courts must order "personal injury tort and wrongful death claims" against a debtor to be "tried in the district court in which the bankruptcy case is pending" or "in the district court in the district in which the claim arose, as determined by the district court in which the bankruptcy case is pending." ${ }^{238}$ The district court in which a bankruptcy court sits has jurisdiction to hear appeals from the bankruptcy court's orders. ${ }^{239} \mathrm{~A}$ bankruptcy petition may be filed only in a bankruptcy court that possesses the proper "venue" over the case, although the venue rules are somewhat flexible. ${ }^{240}$

This structural and stylistic procedural setting of bankruptcy law extends not only to "proceedings" relating to a bankruptcy case, such as an "adversary proceeding" 241 to determine a priority dispute or a hearing on relief from the automatic stay, ${ }^{242}$ but also to the core elements of the bankruptcy case itself. Proceedings relating to a bankruptcy case, of course, are similar to most other civil disputes subject to litigation. But the case itself relates to the most fundamental functions of bankruptcy law-what it is that bankruptcy law in fact accomplishes. At the functional heart of the bankruptcy case the legal

236. See 28 U.S.C. $\$ 157(a)$, (b) (2000) (specifying matters heard and determined by bankruptcy judges).

237. 28 U.S.C. $\$ 157$ (c) (2000).

238. 28 U.S.C. $\$ 157($ b) $(5)(2000)$.

239. See 28 U.S.C. $\$ 158$ (a) (2000) (establishing appeal jurisdiction). In some circuits, however, bankruptcy appellate panels are appointed to hear these appeals. See 28 U.S.C. $\S 158$ (b) (2000) (providing circumstances under which a bankruptcy appellate panel is appointed).

240. In general, venue is conferred on the district court "in which the [debtor's] domicile, residence, principal place of business in the United States, or principal assets in the United States ... have been located for the one hundred and eighty days immediately preceding" the filing. 28 U.S.C. $\$ 1408(1)(2000)$. Venue for a debtor's case also lies in a district court "in which there is pending a case under" the Bankruptcy Code for an "affiliate, general partner, or partnership" of the debtor. Id. $\$ 1408(2)$. Additional venue rules apply to a proceeding "arising under" the Bankruptcy Code "or arising in or related to cases under" the Bankruptcy Code. Id. $\S 1409$.

241. See FED. R. BANKR. P. $7001-87$ (establishing bankruptcy procedure concerning adversary proceeding $[\mathrm{s}]$ ).

242. See 11 U.S.C. $\$ 362$ (a) (2000) (providing that the filing of bankruptcy petition automatically stay acts to, inter alia, collect claims against a debtor or to enforce claims or liens against property of the debtor's estate); 11 U.S.C. $\$ 362$ (d) (2000) (providing grounds on which relief from automatic stay is to be granted). 
entitlements relating to a debtor-primarily "claims" 243 against a debtor and in some cases the "interests" of a debtor's equity security holders ${ }^{244}$-are determined and vindicated. In this way bankruptcy serves the interests of a debtor's rightsholders as civil procedure more generally vindicates the interests of those with legal entitlements who seek judicial relief or satisfaction.

In a Chapter 7 case, the debtor's assets generally are liquidated by the trustee in bankruptcy while the net proceeds, if any, are distributed to the holders of claims and then, in the highly unusual case, the balance of distributable assets are paid to the debtor. ${ }^{245}$ Secured claims are satisfied either fully or to the extent of a relevant collateral value. ${ }^{246}$ In a Chapter 11 case in which a reorganized debtor emerges under a plan of reorganization, ${ }^{247}$ distributions of property are made to the holders of claims in satisfaction of the claims and, sometimes, to holders of interests of equity security holders. ${ }^{248} \mathrm{An}$ essential tenet of both Chapter 7 and Chapter 11 is that nonbankruptcy (usually, state) law defines the metes and bounds of what constitutes a claim or an interest: the beneficiaries of the system and those entitled to participate. ${ }^{249}$

243. See 11 U.S.C. $\$ 101(5)$ (2000) (defining "claim"); see also supra note 4 (quoting Chapter 11's definition of "claim").

244. Although "interest" is not a defined term in the Bankruptcy Code, it is used in the definition of "equity security" and in identifying the rights held by an "equity security holder." See 11 U.S.C. $\$ 101(16)$ (2000) (defining "equity security"); 11 U.S.C. $\$ 101$ (17) (2000) (defining "equity security holder"); 11 U.S.C. $\$ 501$ (a) (2000) (providing for filing of proof of claim by creditor or proof of interest by equity security holder); 11 U.S.C. $\$ 1111$ (2000) (outlining classification of claims and interests).

245. See 11 U.S.C. $\$$ 726(a) (2000) (specifying order in which claims are to be paid). See generally TABB, supra note $136, \$ 7.23$, at $531-34$.

246. See 11 U.S.C. $\$ 506$ (a) (2000) (providing the status of secured claims). Secured claims may be dealt with in several ways. For example, the court could order relief from the automatic stay under 11 U.S.C. $\$ 362$ (d) or abandonment under 11 U.S.C. $\$ 554$, thereby permitting the secured party to enforce its security interest under nonbankruptcy law. Or, the trustee could sell the collateral under 11 U.S.C. $\$ 363$ and pay over the net proceeds to the secured party. A debtor may redeem collateral under 11 U.S.C. 722. A debtor also may agree to reaffirm its debt owed to a secured party, under 11 U.S.C. $\$ 524(\mathrm{c})$, in exchange for the right to retain the collateral while making payments to the secured party. See generally TABB, supra note $136, \S 7.26$, at $544-49$.

247. See generally TABB, supra note $136, \$ \$ 11.14-11.34$, at $806-80$. In some cases a "liquidating plan" provides for the sale of all of the debtor estate's assets. See 11 U.S.C. $\S 1123(\mathrm{a})(5)(\mathrm{D})$ (2000) (stating that the plan may provide for "sale of all or any part of the property of the estate").

248. A claimant or interest holder may receive under a plan payments or property in satisfaction of its claim or interest under a plan of reorganization. See 11 U.S.C. $\S 1129$ (a)(7) (2000) (outlining the best interests test); 11 U.S.C. $\$ 1129$ (b) (2000) (explaining when a court "shall confirm the plan").

249. See TABB, supra note 136, $\$ 7.5$, at 488 ("At its core, bankruptcy remains a procedural mechanism for sorting out claims that are established under nonbankruptcy law."). 
Similarly, nonbankruptcy law delineates what constitutes property and the identity of the holders of property interests that may be involved in bankruptcy. ${ }^{250}$ And it is the allocation of a debtor's property, or its value, to the holders of claims and interests that represents bankruptcy law's core mission.

Any contemporary observer of United States bankruptcy law will ask the inevitable questions. What about debtor relief? What about rehabilitation? What about the individual's debtor-initiated discharge in bankruptcy? Part IV.G deals with procedure theory and the individual debtor's discharge. For present purposes of examining procedure theory from the perspective of civil procedure law and the law of federal court jurisdiction, however, it is sufficient to note that a broad discharge provision is a relatively new phenomenon and the Bankruptcy Code's treatment is far more liberal than laws in most other jurisdictions.

The earliest English bankruptcy legislation contained no provision for discharge. ${ }^{251}$ It was directed toward overcoming the inadequacy of individual creditor remedies through a collective proceeding and, in particular, protecting creditors against fraudulent debtors. ${ }^{252}$ Like conventional creditor judicial enforcement, however, it was strictly involuntary-it was creditor-initiated. ${ }^{253}$ The first English discharge provisions came later in the Statute of $4 \mathrm{Anne}^{254}$ and were short lived. ${ }^{255}$ Even so, it seems clear that the principal role envisioned for the debtor's discharge was to enhance the recoveries of creditors. ${ }^{256}$

The first bankruptcy act in the United States, the Bankruptcy Act of $1800,{ }^{257}$ followed closely the creditor-oriented approach of then existing English bankruptcy law, although it was repealed in $1803 .^{258}$ The on-again-off-

250. See infra Part IV.A (discussing "property of the estate" under 11 U.S.C. $\$ 541$ ). See generally Policy, supra note 40, at 87-89.

251. $34 \& 35$ Hen. 8 , c. 4 (1542-43); 13 Eliz., c. 7 (1570). For an overview of these statutes, see generally Charles Jordan Tabb, The History of the Bankruptcy Laws in the United States, 3 AM. BANKr. Inst. L. REv. 5, 7-11 (1995) [hereinafter Tabb, History].

252. See Tabb, History, supra note 251, at 8-9 (stating that the 1520 law was added to address fraudulent conveyances).

253. Id.

254. 4 Ann., c. 17 (1705). See generally Charles Jordan Tabb, The Historical Evolution of the Bankruptcy Discharge, 65 AM. BANKR. L.J. 325, 333-39 (1991) [hereinafter Discharge].

255. See id. at 339 (noting that in 1706 the English Parliament enacted a provision that required creditor consent as a condition of discharge).

256. Id. at 337 ("Certainly the primary purpose of the act was to facilitate creditors' recoveries; the title of and preamble to the statute make that abundantly clear.").

257. Act of Apr. 4, 1800, ch. 19, 2 Stat. 19, repealed by Act of Dec. 19, 1803, ch. 6, 2 Stat. 248.

258. See Tabb, History, supra note 251, at 14-15 (discussing the repeal of the Bankruptcy 
again history of United States bankruptcy laws in the nineteenth century and the Bankruptcy Code in effect today consistently maintained as an essential component of bankruptcy law the goal of enhancing recoveries of those holding legal entitlements, primarily creditors. ${ }^{259}$

The goal of enhancing recoveries of rightsholders provides a raison d'etre for the efficiencies of collective bankruptcy proceedings as distinct from the enforcement of legal entitlements in general civil litigation. ${ }^{260}$ But over the period from the earliest English bankruptcy law to the end of the nineteenth century other, distinct sets of normative considerations had become accepted: dissatisfaction with the imprisonment of debtors and more general concerns for the welfare of debtors and their need for a "fresh start."261 Although the idea of a bankruptcy discharge was originally seen as a means to enhance creditor recoveries, and it generally may serve that function even today, concern for the plight of an insolvent debtor undoubtedly has achieved normative independence. $^{262}$

The simplest account of procedure theory understands the structural and functional essence of bankruptcy law as a method of enhancing the nonbankruptcy legal entitlements of rightsholders-a goal it shares with civil procedure generally. Along the way procedure theory must explain the rationale for bankruptcy law as a separate branch of procedure as well as role of the discharge. But the normative account of procedure theory of bankruptcy advanced in this subpart is richer than the simple account that states procedural law serves substantive entitlements. It situates bankruptcy law as a part of the structure and law underlying the system of federal courts, federal judiciary, and federal jurisdiction. Bankruptcy scholars have generally overlooked or seriously underemphasized this perspective in the normative debates over bankruptcy theory, philosophy, and policy. ${ }^{263}$ This account recognizes that the

Act of 1800).

259. Id. at 14-22, 23-38 (discussing the evolution of bankruptcy law).

260. See supra Part II.D (answering "Why Bankruptcy?").

261. See generally infra Part IV.G.

262. See infra Part IV.G (discussing the evolution of bankruptcy law).

263. There are important exceptions, including Ralph Brubaker, Christopher Frost, and Thomas Plank. See Frost, supra note 4, at 126 ("Bankruptcy is, in the main, a judicial process much like any other."); infra notes 336-42 and accompanying text (discussing the relevance of Frost's analysis to procedure theory). I draw on Plank's work above and in my discussion of Erie Railroad Company v. Tompkins, 304 U.S. 64 (1938). See infra notes 287-332 and accompanying text (discussing Erie); see also Ralph Brubaker, On the Nature of Federal Bankruptcy Jurisdiction: A General, Statutory and Constitutional Theory, 41 WM. \& MARY L. REV. 743, 941 (2000) ("We must alter the prevailing conception of Bankruptcy in order to assimilate the wisdom of accepted principles of federal jurisdiction."). 
normative underpinnings of bankruptcy law must be viewed as a part of the federal system of justice, the relationship between federal law and state law, the relationship between bankruptcy law, state, and other nonbankruptcy law, and, more generally, federalism and the separation of federal legislative and judicial powers.

Both the Bankruptcy Clause and the Bankruptcy Act of 1800 were influenced by concerns that nonresident commercial interests (read, creditors) were at a disadvantage in seeking to enforce obligations in jurisdictions in which their debtors were located. ${ }^{264}$ This concern was compounded by the nonuniform bankruptcy laws that prevailed in the colonies and thereafter in the states before passage of that act in $1800 .{ }^{265}$ The issues of federalism and

264. See Tabb, History, supra note 251, at 13 ("A bankruptcy law was apparently believed to be a necessary subject of federal legislation because of the problems that varying and discriminatory state laws caused for nonresident creditors and interstate commerce in general."). But see John T. Cross, State Choice of Law Rules in Bankruptcy, 42 OKLA. L. REv. 531, 572 (1989) (asserting that the justifications for bankruptcy courts are "altogether different" from those for federal diversity jurisdiction). See infra notes 272-78 and accompanying text (discussing federal diversity jurisdiction). While I certainly acknowledge that the concerns mentioned in the text are not the only justifications for bankruptcy law, the following discussion demonstrates that Cross's claim is inaccurate.

Here and in the discussion that follows I draw on the origins of United States bankruptcy law and federal court jurisdiction as additional support for procedure theory. But I eschew any attempt to draw a complete or deep picture from an historical perspective. See generally BRUCE

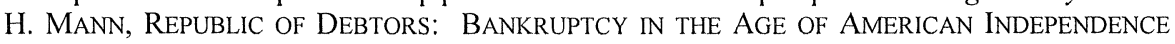
(2002); DAvid A. SkeEl, JR., DebT's Dominion: A History of BANKRUPtCy LAW IN AMERICA 3, 23-47 (2001) [hereinafter DEBT's DOMINION].

265. F. Regis Noel states:

It has been demonstrated that the English code had, in colonial times, been carried across the Atlantic and set up on the shores of America, and the Articles [of Confederation] continued the operation of the principles of that code in each State according to the established and traditional laws. The nature and extent of these laws has been amply illustrated, and it would be misleading to suggest that they ceased to operate or were changed immediately by the [Bankruptcy Clause of the ] Constitution. For, owing to the failure of the Federal government to legislate on the subject, and the obstinacy of the common-wealths, whose congressmen were then more frequently laboring for the local than the general welfare, in yielding to the central and sovereign power anything considered a State right, the regulation of debt remained for many years under the control and administration of the States. ....

Under the ... Articles of Confederation, the creditor classes resisted all schemes for the relief of these private and insurmountable debts, and they suffered considerable losses from the application of State insolvency laws .... The absence of laws protecting manufacturers in interstate and foreign dealings, lack of security in the Western Lands, [and other disruptions] at length turned the inhabitants to the relief of forming a new national government .... [S]ome claimed that the rapacity of creditors, others the depravity of debtors, was responsible for the conditions which 
interstate commerce were at center stage. Joseph Story's commentary on the Bankruptcy Clause is instructive:

The brevity, with which... [the Bankruptcy Clause] is treated by the Federalist, is quite remarkable. The only passage in that elaborate commentary, in which the subject is treated, is as follows: "The power of establishing uniform laws of bankruptcy is so intimately connected with the regulation of commerce, and will prevent so many frauds, where the parties or their property may lie, or be removed into different states, that the expediency of it seems not likely to be drawn in question." [quoting The Federalist, No. 42, at 56 (McLean ed., 1788)].

. . .

[T] here are peculiar reasons ... why the government of the United States should be entrusted with this power [to establish uniform bankruptcy laws]. They result from the importance of preserving harmony, promoting justice, and securing equality of rights and remedies among the citizens of all the states. It is obvious, that if the power is exclusively vested in the states, each one will be at liberty to frame such a system of ... bankruptcy and insolvency [law], as best suits its own local interests, and pursuits .... There will always be found in every state a large mass of politicians, who will deem it more safe to consult their own temporary interests and popularity, by a narrow system of preferences, than to enlarge the boundaries, so as to give to distant creditors a fair share of the fortune of a ruined debtor. ${ }^{266}$

[resulted] ... in the bankruptcy article of the American Constitution. $\ldots$

In order to realize the confusion arising from the multiplex and discrepant State laws for the release of the debtor and the distribution of his effects, prior to the enactment of [the Bankruptcy Act of 1800] . .., it is necessary only to consider the inconvenience and injustice which result from lack of uniformity in our day in the various State laws on divorce, shipping, and insurance.... The misery, the wretchedness, the suffering, the despair, the crime and the injustice of those years are now scarcely comprehensible.

F. REgIS NOEL, A HISTORY OF THE BANKRUPTCY LAW 68-69, 74, 111 (1919) (internal quotations omitted) [hereinafter NOEL, HISTORY]. For an overview of bankruptcy and insolvency laws during the colonial period, see MANN, supra note 264, at 47-67 (outlining colonial bankruptcy laws).

266. JOSEPH STORY, COMMENTARIES ON THE CONSTITUTION OF THE UNITED STATES $\$ \S 1100$, 1105-07 (2d ed. 1857). 
Story's concerns relate to inefficiencies arising out of nonuniformity, ${ }^{267}$ but he also explicitly notes in the quoted passage the inequitable treatment of citizens of different states. Inasmuch as every bankruptcy law ever passed in the United States has placed substantial responsibility for bankruptcy cases in the hands of the United States district courts, it is plausible to surmise that Story's concerns must have extended as well to the potential for unfair and discriminatory judicial administration of separate bankruptcy laws in the states. ${ }^{268}$

Consider also Bruce Mann's lucid description of attitudes of the framers that gave rise to the Bankruptcy Clause:

[T] he idea that bankruptcy raised issues that were better addressed on a national level rather than through the mechanisms of interstate comity seems to have taken at least tentative root during the [constitutional] convention. The lawyers and judges in the two Pennsylvania cases, ${ }^{269}$ and through them some of the key delegates to the convention, clearly recognized the problems inherent in applying state insolvency and bankruptcy rules to debtors and creditors who lived in different states. Credit, like commerce, could not be contained within state boundaries. Full faith and credit helped somewhat, but it could harm out-of-state creditors by imposing on them state bankruptcy discharges that stripped them of their claims without their participation in the process. As [James] Wilson remarked at the Pennsylvania ratifying convention, "Merchants of eminence will tell you that they can trust their correspondents without law; but they cannot trust the laws of the state in which their correspondents live."

267. Noel also offers examples:

The State [bankruptcy] laws were not uniform, and in the same degree were inadequate and subject to great limitations.... A method was required which would render the discharge of a citizen of any State binding in all others; which would establish the same acts and defaults of the debtor as occasions for bankruptcy proceedings in every section; which would abolish the iniquitous privilege of preferences and which would enable the merchant of New York selling to the trader of Boston or New Orleans to feel confident that if unforseen calamity should occur the debtor would not be able to place his assets beyond reach.

NOEL, History, supra note 265, at 120.

268. Story himself is reputed to be the author of the Bankruptcy Act of 1841. Tabb, History, supra note 251, at 16. For a description of the jurisdiction of the district courts under the pre-1898 United States bankruptcy laws, see Brubaker, supra note 263, at 757-65 (detailing the history of bankruptcy courts). See also David Gray Carlson, Security Interests in the Crucible of Voidable Preference Law, 1995 U. ILL. L. REV. 211, 217-18 (1995) [hereinafter Crucible] (noting that voidable preference law served the "nation-building" and nationalism interests by ensuring that secret, local liens would not prevail over national creditors who could not discover the liens).

269. Mann is referring to two cases involving the effect in one state of a bankruptcy discharge under the law of another state. MANN, supra note 264, at 183-85. 
Judges ... were more concerned with punishing fraud, while merchants, whose business was business and who necessarily included debtors as well as creditors, were more interested in Madison's "regulation of commerce." The limited evidence of the Constitutional Convention suggests that the framers had in mind the latter. ${ }^{270}$

In addition to providing support for the Bankruptcy Clause, the same concerns for fair and equal justice in a federal republic have substantially influenced the civil jurisdiction of federal courts more generally. Article III, Section 2 of the Constitution extends federal judicial power to, inter alia "Controversies . . . between Citizens of different States, ${ }^{\text {"271 }}$ so-called "diversity" jurisdiction. While the Constitution permitted but did not require Congress "[t]o establish Tribunals inferior to the [S] upreme Court," ${ }^{\text {"72 }}$ the first Congress did establish a system of lower federal courts ${ }^{273}$ and provided for diversity jurisdiction in the Judiciary Act of $1789 .{ }^{274}$ The normative basis of diversity jurisdiction generally is accepted to be the avoidance of hostility that might be expected from state courts based on the identities of the litigants. One view is that a state court might be hostile to the interests of a citizen of another state. ${ }^{275}$ A competing view is that concerns of the Constitutional framers and members of the first Congress were addressed to "class hostility."276 But both views agree that diversity of citizenship warrants federal jurisdiction. ${ }^{277}$

270. Id. at $185-87$

271. U.S. CONST. art. III, $\$ 2$.

272. U.S. Const, art. I, $\$ 8 \mathrm{cl} .9$.

273. Act of Sept. 24, 1789, 1 Stat. 73.

274. Id. at 78. The act provided that United States circuit courts had jurisdiction if "the suit is between a citizen of the State where the suit is brought and a citizen of another state." The current version provides, in part, that federal "district courts have original jurisdiction of all civil actions where the mater in controversy exceeds the sum or value of $\$ 75,000$, exclusive of interest and costs, and is between . . citizens of different states." 28 U.S.C. $\$ 332(a)(1)(2000)$.

275. FRIEDENTHAL ET AL., supra note 97, at 25 (citing United States v. Deveaux., 9 U.S. (5 Cranch) 61 (1809)).

276. Id. at 25 ("The federal courts offered a means for protecting commercial groups from class bias on the part of democratically inclined state legislatures, which otherwise might pressure state courts into decisions hostile to commercial, manufacturing, and speculative land interests."); see Burbank, supra note 21, at 1323 ("An important reason for the existence of Article III federal judicial power in diversity (including alienage diversity) cases and for the First Congress's decision to create lower federal courts had to do with concerns that state courts were hostile to creditors.").

277. There now is considerable disagreement on whether continuation of federal diversity jurisdiction is wise. See FrIEDENTHAL ET AL., supra note 97, at 25-29 (discussing the disagreement). But, as discussed below, the normative implications of the applicable law in diversity cases for the applicable law in bankruptcy cases is not diminished whether or not 
The principal normative implications of these parallel rationales for federal systems of bankruptcy law and diversity jurisdiction support procedure theory's core principle that bankruptcy law, like trans-substantive civil procedure law, generally should serve the interests of and respect rightsholders' nonbankruptcy legal entitlements. In this respect bankruptcy theorists can draw on lessons learned from experience with federal diversity jurisdiction.

The Judiciary Act of 1789 also contained a provision known as the "Rules of Decision Act." 278 Under that Act, "the laws of the several states" were to apply in "trials at common law" in federal courts. In 1842 the Supreme Court definitively interpreted the Act in Swift $v$. Tyson. ${ }^{279}$ In an opinion written by Joseph Story, the Court held that the reference to "the laws of the several states" did not include decisional law of the courts of the states but referred only to state statutes and constitutions. Aside from purely "local" law matters, ${ }^{280}$ the federal courts would apply the "general" law to matters of general concern. ${ }^{281}$ The legal question addressed in Swift provides an example of "general" lawwhether the transfer and endorsement of a negotiable instrument (a "bill of exchange") to a transferee on account of a pre-existing obligation provide the appropriate consideration for the transfer so that the transferee took free of the obligor's defense. The defendant argued that under New York's "local" decisional law the defense against the original payees was also good as against the transferee. ${ }^{282}$ Under the "general" law as interpreted by the federal courts,

diversity jurisdiction continues to be warranted. See infra notes 319-32 and accompanying text (discussing the Rules of Decision Act and the Erie doctrine).

278. 1 Stat. 92 (1789). The currently applicable version is codified at 28 U.S.C. $\$ 1652$ (2000) and is entitled "State laws as rules of decision."

279. Swift v. Tyson, 41 U.S. 1 (1842).

280. As Justice Story's opinion in Swift explained:

The laws of a state are more usually understood to mean the rules and enactments promulgated by the legislative authority thereof, or long-established local customs having the force of laws. In all the various cases, which have hitherto come before us for decision, this court have uniformly supposed, that the true interpretation of the 34th section [the Rules of Decision Act] limited its application to state laws, strictly local, that is to say, to the positive statutes of the state, and the construction thereof adopted by the local tribunals, and to rights and titles to things having a permanent locality, such as the rights and titles to real estate, and other matters immovable and intra-territorial in their nature and character.

Id. at 18. "[M]arriage, inheritance, and real property" are examples of "local" law. GEOFFREY

C. HAZARD, JR. ET AL., Pleading AND Procedure 484 (7th ed. 1994).

281. Swift, 41 U.S. at 18-19.

282. Id. at $17-18$. 
the defense was not good against the transferee. The Court unanimously held that a federal court should follow the rule under the "general" law. ${ }^{283}$

With hindsight, the incoherence of the rule announced in Swift-applying one body of substantive, federal "general" common law in a diversity case in federal court and another body of substantive, state "local" law in a state court case-was immanent. But Story and the Swift Court appear to have had their hearts in the right place. If the "general" law would be followed by the state courts as well, the system would enhance uniformity of laws among the states. ${ }^{284}$ If both sets of courts were applying the same rules, even though the state courts were not bound to follow them, the incoherence would be minimal. In general, this vision of uniformity held true to form in practice until after the Civil War, when many state courts increasingly parted ways with the "general" law as laid down by the federal courts. ${ }^{285}$

In 1938, the Supreme Court decided Erie Railroad Company $v$. Tompkins, ${ }^{286}$ squarely overruling Swift. Tompkins had sued Erie in a diversity action in federal district court for injuries sustained while Tompkins was walking along a railroad right-of-way. ${ }^{287}$ Under then-existing federal "general" law, Erie owed Tompkins a duty of care and could be liable for negligence. ${ }^{288}$ On this theory, Tompkins recovered judgment on a jury verdict against Erie in the district court. Erie had argued that Pennsylvania law applied, under which Erie contended that it owed Tompkins only the duty that it owed to a

283. Id. at 18-19. Justice Catron's dissent was based on his different view of the applicable rule under the "general" law. Id. at 23.

284. The text states:

The awkwardness that would result from such a disagreement [between a state decision and a conflicting federal court decision] provided further incentive to the state courts to follow the decisions of the federal courts.

For the entire pre-Civil War period, the state and federal courts lived in relative harmony, with the state courts deferring - usually gratefully - to the United States Supreme Court on questions of general law.

Id. at 486 .

285. Id. at 486-87 (discussing the shift in judicial interpretation after the Civil War). Following the Civil War, the decisions of some state courts began to diverge from those of the federal courts as the economic interests of the states also further diverged. Id. In particular, the federal courts "constructed a general law that increasingly favored the creditors and employers." Id. at 486; see also infra notes 307-18 and accompanying text (discussing Brandeis' motivations in writing the Erie opinion).

286. Erie R.R. Co. v. Tompkins, 304 U.S. 64, 78 (1938) (overruling Swift).

287. Id. at 69 .

288. Id. at 70 . 
trespasser. ${ }^{289}$ The Second Circuit affirmed the judgment, relying on the applicability of "general" law. ${ }^{290}$ The Supreme Court reversed.

Except in matters governed by the Federal Constitution or by acts of Congress, the law to be applied in any case is the law of the state. And whether the law of the state shall be declared by its Legislature in a statute or by its highest court in a decision is not a matter of federal concern. There is no federal general common law. Congress has no power to declare substantive rules of common law applicable in a state whether they be local in their nature or 'general,' be they commercial law or a part of the law of torts. And no clause in the Constitution purports to confer such a power upon the federal courts. ${ }^{291}$

Justice Brandeis, writing for the Court, gave three bases for the decision. First, new scholarship demonstrated that Justice Story had misinterpreted the Rules of Decision Act in Swift. ${ }^{292}$ Second, experience under Swift had demonstrated its "defects, political and social; and the benefits expected to flow from the rule did not accrue." 293 The Court explained that the "mischievous ... doctrine" had led to widespread forum-based "discrimination," a result that diversity jurisdiction had been created to prevent. ${ }^{294}$ The Court, however, further explained that although the Swift doctrine's "injustice and confusion" had been argued as reasons to change the rule, these first two bases of its decision would not be sufficient alone to convince the Court to abandon the rule. ${ }^{295}$ But the third basis of its decision was indeed sufficient; the Swift doctrine was unconstitutional. ${ }^{296}$ The pervasive application of federal "general" law to so many areas of substantive law had "invaded rights which in our opinion are reserved by the Constitution to the several states."297

289. Id. at 70-71.

290. Id. at 70 .

291. Id. at 78 .

292. Id. at 72-73 n.5. The opinion cited Charles Warren, New Light on the History of the Federal Judiciary Act of 1789, 37 HARV. L. REV. 49, 51-52, 81-88, 108 (1923), as the "more recent research of a competent scholar." Id. But see HAZARD ET AL., supra note 280, at 494 (stating that Warren's conclusion was "almost certainly incorrect").

293. Erie R.R. Co. v. Tompkins, 304 U.S. 64, 74 (1938). But see Edward A. PurCELL, Jr., Brandeis and the Progressive Constitution: ErIE, the Judicial power, and the Politics OF the Federal Courts IN Twentieth-Century America 141-91 (2000) (challenging the accuracy of the charges of "defects, political and social" as well as Brandeis's candor in leveling them). I discuss Purcell's analysis of Brandeis's motivations and conclusions below. See infra notes 307-16 and accompanying text (discussing the overruling of Swift).

294. Erie R.R. Co. v. Tompkins, 304 U.S. 64, 74 (1938).

295. Id. at 77.

296. Id. at $77-78$.

297. Id. at 80. Justice Reed concurred in part on the basis of the proper interpretation of 
The Supreme Court as well as lower courts have struggled to find the appropriate line between substantive state law to be respected by federal courts and procedural federal law that will apply in federal courts even in diversity cases. The rules implicated in Swift - the effect of a good faith purchase of a negotiable instrument for pre-existing value-and Erie-the nature of a railroad's duty to a person walking along a right-of-way-were straightforward and obviously substantive. But as the Erie doctrine has continued to evolve the Court has dealt with a variety of matters in diversity cases, including state-law statutes of limitations, ${ }^{298}$ whether the determination of a plaintiff's status as a statutory employee should be made by a judge as under applicable state law or by a jury, ${ }^{299}$ and the applicability of the Federal Rules of Civil Procedure. ${ }^{300}$ It is not necessary to dissect fully the whole of Erie jurisprudence for the present purpose of examining the Erie doctrine's support for the normative

the reference to "the laws" in the Rules of Decision Act, but he refused to join in the majority's conclusion that the Swift doctrine was unconstitutional. Id. at 90-92. Justices Butler and McReynolds concurred in the result on the basis of the plaintiff's contributory negligence while noting that no constitutional question had been raised. $I d$. at 80-90. Some have questioned the soundness of the constitutional basis for the decision.

Justice Brandeis appears also to argue that the federal judiciary, as distinct from the federal government as a whole, is not constitutionally empowered to create rules in these areas, especially when those rules are available only to litigants who can invoke the diversity jurisdiction. This is an important argument, based partly on separation of powers and partly on fairness. It is not clear, however, that the argument sustains a conclusion of unconstitutionality of judicial action. Further, the argument in no way disables the federal government from enacting generally applicable federal statutory law in these areas. HAZARD ET AL., supra note 280 , at 496 .

But many believe that Erie's constitutional basis remains relevant and real. See, e.g., PURCELL, supra note 293, at 302 ("By the [twentieth-]century's last decade there was relatively widespread consensus that Erie was a decision of fundamental importance and considerable agreement that it reached constitutional stature."); Thomas E. Plank, The Erie Doctrine and Bankruptcy, 79 NOTRE DAME L. REV. 633, 644 (2004) [hereinafter Erie Doctrine] ("[I]n the case of Congress's Bankruptcy Power, the primary meaning of Erie retains significant force.").

298. Guaranty Trust Co. v. York, 326 U.S. 99, 109-10 (1945) (providing New York statute of limitations applied in case seeking equitable relief because its application was outcome determinative).

299. Byrd v. Blue Ridge Rural Elec. Coop., Inc., 356 U.S. 525, 533-40 (1958) (applying balancing test based on extent to which a state rule is bound up in definition of rights and obligations, strong federal policy of maintaining appropriate judge-jury relationship, and likelihood outcome would be affected, held question of status as statutory employee was for jury).

300. Hanna v. Plumer, 380 U.S. 460, 463 (1965) (providing that substituted service of process under F.R.C.P. 4(d)(1) is applicable notwithstanding state law's "in-hand" delivery requirement; stating that "outcome-determinative" test should be applied in light of dual goals of Erie doctrine to discourage forum-shopping and to prevent the inequitable administration of justice; concluding that a Federal Rules of Civil Procedure rule must be applied unless the rule is not within scope of the Rules Enabling Act). 
underpinnings of the procedure theory of bankruptcy. But it is important to examine Erie's principal normative components. Justice Harlan may have captured that element best in his concurring opinion in Hanna v. Plumer: ${ }^{301}$

Erie was something more than an opinion which worried about "forumshopping and avoidance of inequitable administration of the laws, ... although to be sure these were important elements in the decision .... Erie recognized that there should not be two conflicting systems of law controlling the primary activity of citizens, for such alternative governing authority must necessarily give rise to a debilitating uncertainty in the planning of everyday affairs. ${ }^{302}$

Harlan appreciated the unfairness of a forum-based system (quoting the Court's reference in its Erie opinion to "inequitable administration"), ${ }^{303}$ but he also makes an instrumental claim that such a system creates a "debilitating uncertainty." ${ }^{304}$ Note however that Harlan is not suggesting, nor does anything in the Erie jurisprudence suggest, that deference is made to state decisional law because the substance of that law is normatively superior - however measured, on instrumental standards or otherwise - to the "general" law that federal courts created and sustained under Swift. The inequity as well as the uncertainty, then, derives from the essential incoherence of having different bodies of law apply to "primary activity" based on the fortuity of the forum involved.

What, exactly, was the nature of the concern over forum-shopping under Swift? Given Swift's incoherent doctrine of applying substantive rules based on whether the forum was a federal or state court, forum-shopping was simply the manner in which this incoherence was manifested. Parties will always "forumshop" if the opportunity is present. Forum-shopping thereby gave effect to injustice in the Swift era, but it was the incoherent application of different substantive rules in different fora (not forum-shopping) which was the source of the injustice. ${ }^{305}$ Indeed, the very rationale of diversity jurisdiction-the avoidance of discrimination against noncitizens in the state courts ${ }^{306}$ - is based on a type of forum-shopping. If this rationale is sound, then diversity

301. Id.

302. Id. at 474 (Harlan, J., concurring).

303. Id.

304. Id.

305. The critique of forum-shopping in the Erie context should be distinguished from the forum-shopping critique of Baird and Jackson. Their critique is based on the idea that adjusting nonbankruptcy entitlements in bankruptcy will provide perverse incentives to resort to bankruptcy or to eschew bankruptcy in inappropriate circumstances. See supra note 199 (discussing Baird and Jackson's creditors' bargain theory).

306. See supra notes 276-78 and accompanying text (discussing the reasons for diversity jurisdiction). 
jurisdiction appropriately encourages forum-shopping - commencing an action in or removing an action to a federal court-for a better quality of justice.

Edward Purcell's account of Justice Brandeis's role in influencing the result in Erie and writing the opinion of the Court further illuminates its normative basis. Brandeis saw in Erie an irresistible opportunity to overrule Swift (and perhaps the last opportunity during his tenure on the Court), ${ }^{307}$ a result that Brandeis had long advocated. ${ }^{308}$ A majority of the Court favored the overturning of Swift at the first conference of the Justices following oral argument of the case. ${ }^{309}$ But it was Brandeis who was the primary advocate for doing so on constitutional grounds. ${ }^{310}$ His determination to ground Erie's overruling of Swift on the Constitution accounts for the artful nature of his opinion, which was carefully designed to hold the support of a majority. ${ }^{311}$

307. See PuRCELl, supra note 293, at 137 (discussing Brandeis's motivations). The text states:

Although Brandeis had no intention of leaving [the Court], especially in the face of pressure, the political battles and personal wounds of 1937 forced him to recognize that only a short time remained to him and that the end of his tenure could come quickly and unexpectedly. It was most unlikely that he would have another chance at Swift.

Id.

308. Id. at 101 (discussing Brandeis's reasoning).

309. Only eight Justices sat when Erie was argued, Justice Cardozo being absent due to illness. Id. at 102. At the first conference Brandeis, Justice Stone, and Chief Justice Hughes supported overruling Swift from the outset. Id. Justices Butler and McReynolds supported Swift and were opposed to abolishing its doctrine. Id. Justices Black, Reed, and Roberts then voted in favor, resulting in a majority of six for overruling Swift. Id. Reed, however, later refused to embrace the constitutional basis of the majority opinion, choosing instead to base his concurrence on an interpretation of the Rules of Decision Act. Erie R.R. Co. v. Tompkins, 304 U.S. 64, 90-92 (1938) (Reed, J., concurring). Interestingly, the majority emerged even though the counsel for the Erie Railroad (whose client stood to gain in the case by overruling Swift) refused, during oral argument, to take a position in favor of abolishing Swift. PURCELL, supra note 293, at 97-101. Purcell explained that the railroad in most situations was a beneficiary of the Swift doctrine and wished to preserve it. Id. at 100.

310. Id. at 101 ("Sometime in late 1937 or early 1938 Brandeis decided to make the Erie Railroad's appeal the instrument of Swift's demise. The Court's decision to overrule Swift, and especially its decision to do so on constitutional grounds, was largely due to him."); see also id. at 109-12 (rebutting "inaccurate" claims that Justice Stone or Justice Black played a major role in the Erie decision).

311. Id. at 163-64. Purcell explains several of Brandeis's reasons for writing "a flawed, abstract, oblique, and misleading opinion." $I d$. at 163 . But Purcell primarily emphasizes that Brandeis's more typical Progressive social critique of a "particular social discrimination" would have been "politically divisive" and that the "neutral analysis" adopted by Brandeis in the opinion ensured that Brandeis could maintain the bare majority of justices supporting the constitutional basis for overruling Swift. Id. Nonetheless, Purcell reserves some of his most trenchant criticism for Henry Hart who, in the 1950s "elided [Erie's] . . Progressive political and social values and transformed [Erie] . . . into an abstract symbol of federalism and the rule 
Unlike earlier dissenting opinions in which Brandeis sharply and explicitly advocated for Progressive values and against the entrenched power of large corporate wealth, the Erie opinion is abstract and neutral. ${ }^{312}$

Significantly, the opinion in Erie also is abstract-even crypticconcerning the precise nature of the unconstitutionality of the Swift doctrine. Some language evokes concerns about constraints on federal power that might be read to implicate the Tenth Amendment. ${ }^{313}$ But that was not any part of Brandeis's analysis. ${ }^{314}$ Certainly, the opinion evokes a concern for federalism and the respect that the federal government owes to the states. ${ }^{315}$ But Purcell identifies the core of Brandeis's objection to Swift as the separation of judicial and legislative powers and the respect that the federal judiciary should observe toward Congress:

Erie's declaration that Swift was unconstitutional, then, was a conclusion drawn from two premises: first, that the Constitution inscribed the principles of coextensive powers and legislative primacy; and, second, that Swift stood for the proposition that the federal courts could make law in areas where "Congress was confessedly without power" to act.... [Brandeis] was only affirming two points. One was that Swift permitted the federal courts to act beyond the constitutional reach of the federal judicial power because it allowed them to make rules presumptively beyond the scope of congressional authority. The other point was that the federal

of law." Id. at 229; see also id. at 246-55 (critique of Hart's Erie analysis).

312. Id at 163-64.

313. Erie R.R. Co. v. Tompkins, 304 U.S. 64, 79-80 (1938) (discussing the authority of the state). In the majority, Brandeis states:

Supervision over either the legislative or the judicial action of the states is in no case permissible except as to matters by the constitution specifically authorized or delegated to the United States. Any interference with either, except as thus permitted, is an invasion of the authority of the state, and, to that extent, a denial of its independence.

$\ldots$

We merely declare that in applying the doctrine this Court and the lower courts have invaded rights which in our opinion are reserved by the Constitution to the several states.

Id.; see U.S. CONST. amend. X ("The powers not delegated to the United States by the Constitution, nor prohibited by it to the States, are reserved to the States respectively, or to the people."). The opinion also quotes the dissent of Justice Field, which cited the Tenth Amendment, in Baltimore \& Ohio R.R. Co. v. Baugh, 149 U.S. 368, 401 (1893). Erie, 304 U.S. at 78. Although the Erie opinion did not mention the Tenth Amendment by name, the extensiveness of the quotation of Justice Field's dissent was a concession by Brandeis to Chief Justice Hughes. PURCELL, supra note 293, at 179.

314. Brandeis was strongly opposed to a "substantive interpretation" of the Tenth Amendment that could be used to restrict Progressive New Deal legislation. Id. at 178.

315. See supra note 300 and accompanying text (discussing Hanna). 
courts should not, without compelling reason, displace state rules with those of their own making because Congress had not passed legislation to cover the facts of Erie. . $^{316}$

Thus, Brandeis believed that it was a constitutional wrong for the federal judiciary to make law in areas that were beyond even the power of Congress to legislate. ${ }^{317}$ And Brandeis's views, expressed through Erie, extended even further to condemn federal judicial lawmaking on matters on which Congress could legislate but on which Congress had not acted. ${ }^{318}$

When the Rules of Decision Act or the Erie doctrine dictates that bankruptcy courts apply state law the result is fully consistent with procedure theory. ${ }^{319}$ John Cross has explained how the Rules of Decision Act applies in bankruptcy. ${ }^{320}$ Plank details how the Erie doctrine applies in bankruptcy courts and the constraints that the doctrine imposes by virtue of the limitations

316. PURCELL, supra note 293, at 177 (quoting Erie, 304 U.S. at 72); see also id. at 173 ("Brandeis... wanted to established the principle that the mere possibility of valid congressional legislation was by itself insufficient to authorize the national courts to make law in an area. Congress, not the courts, should determine when and where national lawmaking authority was exercised.").

317. Plank considers this to be the "core" Erie doctrine. Erie Doctrine, supra note 297, at 642-44.

318. This strand of the Erie doctrine rests not only on federalism considerations but on the constitutional separation of judicial and legislative powers. See PETER W. LOW \& JOHN C. JEFFries, JR., FEDERAL COURTS AND tHE LAW OF FEDERAL-STATE RELATIONS 279-80 (2d ed. 1989); Erie Doctrine, supra note 297, at 649 (discussing the separation of powers and the Constitution).

319. That the Rules of Decision Act and Erie apply to bankruptcy courts is implicit in this point. Cross, supra note 264, at 545-56 (discussing the Rules of Decision Act and its application to bankruptcy courts); Erie Doctrine, supra note 297, at 652-60 (discussing the Erie doctrine's application in bankruptcy courts); Alfred Hill, The Erie Doctrine in Bankruptcy, 66 HARV. L. REV. 1013, 1031-36 (1953) (explaining that Erie doctrine applies in bankruptcy courts). Vern Countryman took the position that the Erie doctrine does not apply in bankruptcy. See generally Vern Countryman, The Use of State Law in Bankruptcy Cases (Part I), 47 N.Y.U. L. REV. 407 (1972); Vern Countryman, The Use of State Law in Bankruptcy Cases (Part II), 47 N.Y.U. L. REV. 631 (1972). Plank provides a trenchant and convincing critique of Countryman's position. Erie Doctrine, supra note 297, at 19-24. For an excellent discussion of the interrelationships among the Rules of Decision Act, the Erie doctrine, and federal common law in the context of interjurisdictional (state-federal) preclusion, see generally Stephen B. Burbank, Interjurisdictional Preclusion, Full Faith and Credit and Federal Common Law: A General Approach, 71 CORNELl L. ReV. 733 (1986).

320. Cross, supra note 264 , at 545-56. As in other cases in a federal court, the applicability of state law in a bankruptcy case is subject to exceptions. Id. at 546-52. Cross argues for a choice-of-law rule in bankruptcy that relaxes the rule of Klaxon Co. v. Stentor Electric Manufacturing Co., 313 U.S. 487 (1941). Klaxton holds that, under the Erie doctrine in adversity case, the court must look to the choice-of-law rule of the forum. Klaxton, 313 U.S. at $557-74$. 
imposed on courts by the Bankruptcy Clause. ${ }^{321}$ Plank argues that under the "core" Erie principle bankruptcy courts must apply state law when dealing with an issue outside the scope of the Bankruptcy Clause. ${ }^{322}$ Under the separation of powers strand of Erie, the bankruptcy courts also should follow nonbankruptcy law even when addressing an issue that is within the scope of the Bankruptcy Clause but as to which Congress has not acted. ${ }^{323}$ In Plank's view, the Court "applied this [latter] understanding of Erie" in Butner v. United States, ${ }^{324}$ although the Butner Court did not cite Erie. ${ }^{325}$ But Plank criticizes Butner's exception to the application of state law in determining the existence and nature of property rights in bankruptcy. ${ }^{326}$ Under Butner, state law applies "[u]nless some federal interest requires a different result." Plank argues that even if a bankruptcy court believes that a federal bankruptcy policy does require a result different from the applicable state property law, a bankruptcy court is constitutionally required to apply state law if implementing the federal policy is outside the scope of the Bankruptcy Clause. ${ }^{327}$

Procedure theory of bankruptcy is not doctrinally grounded on the Rules of Procedure Act or the Erie doctrine. That act and Erie address only the source of law applicable in federal courts; procedure theory is broader. Procedure theory instructs Congress as well as the courts. But procedure theory is normatively based on the same grounds of coherence and justice as the Erie doctrine. That is, the fortuity of the forum should not control the applicable substantive law. For example, consider the possibility that Congress might enact a law codifying the rule of Swift - that the federal courts can develop and apply a "general" common law unburdened by state-law doctrine- that would

321. Erie Doctrine, supra note 297, passim.

322. Id. at $645-48$.

323. Id. at 649-52.

324. Butner v. United States, 440 U.S. 48, 54 (1979) (stating Congress has the authority to create federal bankruptcy law but has left it to the states). Butner is addressed in more detail in Part IV.A.

325. Erie Doctrine, supra note 297 , at $649-52$.

326. Id. at $651-52$.

327. Id.; see supra notes 216-17 and accompanying text (discussing Plank's views on the scope of the Bankruptcy Clause); see also Burbank, supra note 319, at 789-90 (discussing federal courts obligation to apply state law) (footnotes omitted). The text provides:

Federal courts are not free to conjure up "interests"; rather, they must tie them to policies already articulated in, or at least articulable from, valid legal prescriptions. The natural tendency of institutions to seize the moment to expand their power is thus bounded by a requirement of resort for authority to policy choices made on other occasions through different, more democratic, processes. 
be applicable only in federal courts. Although it might run afoul of Erie's constitutional mandate, that act of Congress would remove the resulting statute from the applicability of the Rules of Decision Act. ${ }^{328}$ But this codification of the Swift doctrine would be no more coherent and no more just than was the judge-made Swift doctrine itself. And the same normative and legal objections would obtain if the statute provided for the application of the Swift rule only in bankruptcy cases. ${ }^{329}$

Under this analysis procedure theory also would condemn judge-made, discretionary decisions applying principles in a bankruptcy-only context that have no necessary connection with bankruptcy powers or purposes. The plant closing example discussed in Part III.A is an example. ${ }^{330}$ The relevant considerations of community interest and continued employment are present both in and out of bankruptcy and do not differ depending on the context or forum.

A last word on Erie and procedure theory is necessary. One might see a conflict, or at least some irony, in the need for the Bankruptcy Clause and a federal bankruptcy law creating a national system for bankruptcy ${ }^{331}$ and procedure theory's normative claim that bankruptcy law generally exists to vindicate nonbankruptcy (mostly state law) legal entitlements. Any conflict, or irony, is superficial, however. Bankruptcy law is a part of a procedural system for the administration of justice, just as are diversity jurisdiction and the Rules of Decision Act. Under Erie, the Rules of Decision Act, and procedure theory alike, the federal courts - and Congress, under procedure theory-must look outside the federal judicial system for the substance of the relevant legal entitlements. Stated simply, a federal system for bankruptcy law makes sense; varying the legal entitlements based solely on the forum, however, does not. ${ }^{332}$

328. See Burbank, supra note 319, at 756 n. 102 (suggesting that the constitutional aspect of Erie might extend to Congressional powers).

329. Now if there were some rational bankruptcy-related justification for the statutory override of nonbankruptcy law (state law, in the example at hand) in bankruptcy, such a statute could be squared with both the Constitution as well as procedure theory on the basis of the Bankruptcy Clause. See infra Part IV (explaining consistency of many "special" bankruptcyonly rules with procedure theory). And, presumably, the forum would not be "fortuitous." But lacking any such justification, the statute would contravene directly the normative ground on which the Erie doctrine was based and has evolved.

330. See supra notes 125-29 and accompanying text (discussing employees as rightsholders). The same could be said of a judge-made bankruptcy-only priority rule.

331. See supra Part II.D (discussing the justification for bankruptcy law).

332. To the extent that the Bankruptcy Code unjustifiably varies nonbankruptcy law, as opposed to variance pursuant to the exercise of judicial discretion, the variation may produce less uncertainty than was experienced under Swift. But that observation goes to the degree of injustice, not the character of the injustice. 
Finally, Christopher Frost's thoughtful analysis of the bankruptcy process provides additional support for the procedural account of procedure theory. ${ }^{333}$ Frost argues that the bankruptcy process in particular and the judicial process more generally are incapable of rationally redistributing losses from rightsholders to nonrightsholders. ${ }^{334}$ His argument assumes, without conceding, "the social costs accompanying business failure should be spread over a broad base." ${ }^{135}$ Frost accepts and elucidates the common critique that under current law indirect redistributions are ubiquitous in Chapter 11 cases by virtue of delay and the institutional biases that favor rehabilitation. ${ }^{336} \mathrm{He}$ concludes that this "method of indirect protection [of noninvestor interests] is incoherent at best." ${ }^{337}$ But his most trenchant argument is that any judicial process, including the bankruptcy process, is ill-suited for addressing social problems such as the appropriate allocation of costs of business failure. ${ }^{338}$ In particular, Frost persuasively explains that a judicial process is incapable of taking into account the interests not directly involved in the case at hand. ${ }^{339}$

Frost has convincingly taken on the proponents of redistribution in bankruptcy head on. But his analysis differs somewhat from procedure theory as presented here. Implicit in Frost's argument is that assuming the costs of business failure should (however the "should" might be determined) be spread,

333. See generally Frost, supra note 4.

334. Id. at 77, 138-39. Frost uses the terms "investors" (rightsholders) and "non-investors" (nonrightsholders).

335. Id. at 77.

336. Id. at 91-103.

337. Id. at 102 .

338. Id. at 112-40. Janger apparently believes that Frost's critique of the judicial process is irrelevant. Janger, supra note 64, at 614 ("[T]o the extent that the debate between proceduralists and traditionalists turns on differing assessments of the ability of judges to identify opportunistic or abusive behavior, or to identify businesses that are worth saving, it would appear to be a red herring."). Janger argues that "muddy" rules, even when applied by incompetent (but unbiased) judges, lead to more efficient outcomes. Janger, supra note 64, at 582. But he fails to appreciate, perhaps, that the redistributive propensities in bankruptcy probably do reflect a judicial bias in favor of reorganization as an end in itself.

339. Frost points to the imperfect information available to a court and the difficulty of defining the group that will bear the costs. Frost, supra note 4, at 112-13. He also explains that a coherent implementation of a redistributive policy must take into account its impact on the cost of capital in the economy, on demand, on the relevant industry affected. Id. at 116-23. And he demonstrates the judicial system is poorly equipped to deal with "highly polycentric problems" when compared with "other institutions." Id. at 124; see also Barry S. Schermer, Response to Professor Gross: Taking the Interests of the Community Into Account in Bankruptcy A Modern-Day Tale of Belling the Cat, 72 WASH. U. L.Q. 1049, 1053 (1994) (stating that Professor Gross's proposal that bankruptcy courts take into account community interests is not feasible, but does provide "good fiction"). 
it would be normatively acceptable to do so in bankruptcy so long as it were possible to do so rationally. Procedure theory, consistent with the Erie doctrine, teaches that it would be irrational and incoherent to do so based on the identity of the forum (bankruptcy) even if a court could be confident that it was providing a normatively superior and rational result. But this difference does not diminish the persuasiveness of Frost's principal conclusions.

To summarize, bankruptcy law generally bears the unmistakable hallmarks of civil procedure law. Its history, purpose, and demonstrable function demonstrate that its primary role is the determination, resolution, enforcement, and vindication of legal entitlements relating to a debtor. The historical origin of the Bankruptcy Clause has common roots with the constitutional permission given Congress to establish diversity jurisdiction. The normative purchase of, and in some cases, applicable legal doctrine under, the Rules of Decision Act and the Erie doctrine support procedure theory's claim that bankruptcy law must respect the nonbankruptcy legal entitlements of rightsholders in the absence of an adequate justification for a bankruptcy-only rule, standard, or consideration that is based on the core principles of bankruptcy.

\section{E. A Public Choice Account of Procedure Theory}

Substantive bankruptcy-only legal rules that override nonbankruptcy law without bankruptcy justifications, however implemented and whether or not conceived as "reforms" of nonbankruptcy law, raise additional normative concerns. The enormous power and influence over bankruptcy law that bankruptcy lawyers and other bankruptcy professionals exercise is well known. ${ }^{340}$ Bankruptcy lawyers and other professionals are paid first out of the bankruptcy estate's unencumbered assets. ${ }^{341}$ These are not "neutral" law reformers. The public-choice account of procedure theory assesses this environment, in which bankruptcy-only adjustments of nonbankruptcy entitlements emerge from the proposals and influence of bankruptcy law specialists, the interpretation and application of law by bankruptcy courts, and bankruptcy legislation filtered and massaged by the Senate and House Judiciary Committees. Whether in the legislative arena or in the bankruptcy courts, the legislators, judges, individuals, and groups that influence bankruptcy law are

340. See generally infra notes 344-69 and accompanying text.

341. Administrative expenses such as the attorneys fees for counsel to a debtor receive first priority. See 11 U.S.C. $\$ 503(\mathrm{~b})$ (2000) (providing for the allowance of administrative expenses); 11 U.S.C. $\$ 507(\mathrm{a})(1)$ (2000) (providing that administrative expenses have priority). 
not the appropriate actors to make and shape law that has no rational bankruptcy-only justification.

In his compelling history of United States bankruptcy law, Debt's Dominion, David Skeel has documented and explained the power and influence of bankruptcy lawyers on the direction of bankruptcy law, particularly in the twentieth century following enactment of our first "permanent" bankruptcy law, the Bankruptcy Act of $1898 .{ }^{342}$ Skeel blends the perspectives of the interest group branch of public-choice theory with a thoughtful historical study. ${ }^{343} \mathrm{He}$ identifies the bankruptcy bar as the single most influential group in shaping bankruptcy law during the past century. ${ }^{344}$ Bankruptcy lawyers are scattered around the country, affording widespread national influence. ${ }^{345}$ On the other hand, within a given local community the bankruptcy bar historically has been concentrated. ${ }^{346}$ Skeel explains that "[t]he combination of local concentration and a nationwide presence made it much easier for bankruptcy lawyers than for many other groups to coordinate. ${ }^{\text {"347 }}$ Moreover, many other interest groups have a narrower scope of interest in bankruptcy than the bankruptcy bar. ${ }^{348}$ For example, although the bankers' lobby has been influential, banks generally are pacified if their collateral is protected and the costs of losses can be passed off to their customers. ${ }^{349}$

Skeel points to other explanations for the influence of bankruptcy lawyers. The apparent complexity and technical character of the subject adds to the influence of the bar. ${ }^{350}$ This is especially so as to matters difficult for the public and lawmakers alike to understand, even though they may be matters of great importance. ${ }^{351}$ Lawyers typically are the only witnesses in Congressional hearings on technical matters; their expertise offers "an ongoing opportunity to

342. See generally DEBT's DOMINION, supra note 264, at 14-16, 80-98.

343. Id. For an extensive overview of public choice literature, see generally David A. Skeel, Jr., Public Choice and the Future of Public Choice-Influenced Legal Scholarship, 50 VAND. L. REV. 647 (1997).

344. DEBT's DOMINION, supra note 264, at 15 (stating that bankruptcy lawyers and judges had the most influential impact on bankruptcy law).

345. See id. at 86 (discussing the location and influence of bankruptcy lawyers).

346. See id. ("Bankruptcy practice was quite concentrated.").

347. Id. The bankruptcy bar also coordinated its influence through the Commercial Law League and the American Bar Association. Id.

348. See id. at 87 (discussing the narrower interests of banks).

349. Id. at 86 .

350. See id. at 87 ("Another crucial factor in the influence of bankruptcy professionals is the perceived complexity of bankruptcy law.").

351. See id. ("[I]nterest groups often prove most successful in complex areas of the law."). 
influence the legislative process." ${ }^{352}$ This opportunity extends well beyond testimony at hearings; they also participate in drafting and proposing statutory language and work directly with Congressional staff members. ${ }^{353}$

In the legislative process, bankruptcy lawyers frequently adopt a familiar feature of their bankruptcy practices - they advocate on behalf of a variety of interests. ${ }^{354}$ Accordingly, they do not speak with a unified voice, as some advocate for interests of debtors, creditors, or both. ${ }^{355}$ By representing a range of interests, the bankruptcy bar provides some obvious benefits to the political process; it ensures representation for interests that otherwise "might be underrepresented." 356 But Skeel also identifies a darker side of the representative role of bankruptcy lawyers in the legislative process. First, they "are likely to look out for their own interests" on some issues. ${ }^{357}$ Second, bankruptcy lawyers' representative or agency functions leave one important group of players behind without representation. Skeel calls this unrepresented group the "repayers," or debtors "not likely to ever invoke bankruptcy laws." 358 As the bankruptcy lawyers focus on the bankruptcy process, they lose sight of those outside the process. ${ }^{359}$ I would add a third concern that derives from the interplay between the bankruptcy lawyers' representative function and their self-interest. Their representative role tends to mask or at least divert attention away from inherent self-interest, raising a somewhat insidious aspect of bankruptcy lawyers' dominant role in the process.

Skeel identifies two overarching marks of the bankruptcy bar's influence in the legislative process. First, the bar has successfully fought off efforts to impose a governmental administrator or overseer for bankruptcy cases. ${ }^{360}$

352. Id.

353. See id. at 88 ("In addition to their testimony at hearings, bankruptcy professionals leave their fingerprints on almost every other step of the process .... Given their participation in every phase of the legislative process, bankruptcy professionals have an enormous influence on the shape of any proposed legislation.").

354. See id. ("Lawyers serve as the agents of a wide range of interests.").

355. Id.

356. Id.

357. Id. at 89. Skeel points out:

Limiting the fees that can be paid to lawyers might reduce the costs of bankruptcy for debtors, but one does not often see lawyers taking the lead on this kind of proposal. Nor does one often see creditors' lawyers lobbying for measures that would curtail debtors' right to file for bankruptcy, even if such a change would Id. benefit creditors by reducing their losses in bankruptcy.

358. Id

359. Id.

360. See id. at 89-93 (discussing the bankruptcy bar's ability to defeat reform). 
Second, the bankruptcy bar "spearheaded the relentless expansion of bankruptcy law over the course of the [twentieth] century." 361

The bankruptcy bar's influence over bankruptcy law extends beyond the legislative process, of course. Only a select few bankruptcy lawyers actually testify before Congressional committees and engage in drafting proposed legislation, although considerably more are active in organizations that participate in these legislative activities. But most bankruptcy lawyers and bankruptcy judges use, apply, argue, and shape bankruptcy law primarily as actors "on the ground." It is in the bankruptcy courts, and within negotiations in the courts' shadows, where bankruptcy law is made and shaped by a particular legal culture. ${ }^{362}$ Bankruptcy law in a given bankruptcy court also is a function of the attitudes of bankruptcy judges, who have substantial control over the fate of a case, especially in Chapter $11 .^{363}$

The influences of bankruptcy law on the ground are perhaps more subtle than the bankruptcy bar's visible participation in lawmaking in the legislative sphere. But they are every bit as real. In both arenas the bankruptcy bar has a vested interest in much of the status quo. As Skeel has pointed out, one does not see the bar acting against its interests. ${ }^{364}$ This statement does not at all suggest that individuals and organizations do not have a public-minded interest in improving the law. But it does suggest that it is unlikely that they would advocate for fundamental changes that would render their professional positions vulnerable or substantially less necessary. Equally unlikely is the advocacy of reforms that would materially reduce the financial rewards that the current system provides to the bankruptcy bar.

Another important feature of the bankruptcy bar's influence is the emphasis and focus on results of the bankruptcy law on actual bankruptcy cases. This focus comes at the expense of taking into account the instrumental impact of bankruptcy law on the behavior of actors outside bankruptcy. ${ }^{365}$ The

361. See id. at 89, 93-98 (discussing the bankruptcy bar's ability to resist expansion).

362. See, e.g., Teresa A. Sullivan et al., The Persistence of Local Legal Culture: Twenty Years of Evidence from the Federal Bankruptcy Courts, 17 HARV. J.L. \& PUB. POL'Y 801, 859 (1994) (using the bankruptcy system to highlight the influence of "local legal cultures").

363. Decisions made early on in a Chapter 11 case, for example, such as whether to lift the automatic stay at a secured creditor's request or to deny the creditor requested "adequate protection," can have an enormous impact on a case or on creditor's ultimate recovery. See infra Part IV.J (discussing adequate protection and lifting of the automatic stay). I do not mean to suggest that all bankruptcy judges have similar views, however.

364. See supra note 357 (discussing the role of bankruptcy lawyers).

365. Baird identified the tendency to disregard this instrumental and ex ante impact as a characteristic of the traditionalist approach to bankruptcy law. See Axioms, supra note 50, at 589-90 (stating the traditional belief that "[b]ankruptcy law can largely ignore ex ante efforts and that it can push parts in beneficial directions"). 
status quo bias and the narrow focus on the effects of bankruptcy law only in bankruptcy cases plausibly account for the redistributive characteristics and effects of the effective bias towards rehabilitation in Chapter 11-in the statute as well as on the ground. ${ }^{366}$ Keeping the debtor afloat gives rehabilitation a chance. When a debtor floats on the backs of rightsholders that could benefit more from prompt liquidation, the bankruptcy bar collects. This redistributive rehabilitation bias directly offends procedure theory. ${ }^{367}$

It may be that the grip of the bankruptcy bar on bankruptcy law and the process for "reform" has waned somewhat in recent years. Certainly the bills currently pending in Congress have been influenced substantially by the lobby of the consumer credit industry ${ }^{368}$ and have met considerable criticism from the bankruptcy bar. ${ }^{369}$ On the other hand, the bankruptcy bar more or less dominated the work of the National Bankruptcy Review Commission. And none of the major reform bills introduced in recent years have passed.

The public choice perspective on procedure theory goes considerably beyond the influence of the bankruptcy bar and other interest groups and its critique of Chapter 11's redistributive bias. This perspective complements the jurisprudential/incoherence and civil procedure/federal courts accounts of procedure theory. Simply put, the Judiciary Committees of Congress and the bankruptcy courts are inappropriate actors and fora for the development, promulgation, and implementation of bankruptcy-only legal rules and decisions on matters that have no legitimate bankruptcy-only justification.

This aspect of the public choice perspective addresses both the legislative and judicial processes affecting bankruptcy law. As already discussed, Chapter 11 's redistributive bias that has resulted from these processes cannot be squared with procedure theory. ${ }^{370}$ But at least the matter of rehabilitating distressed debtors clearly is one within the proper domain of bankruptcy law. Using the

366. See, e.g., 11 U.S.C. $\$ 1121$ (a) (2000) (providing a 120 day exclusivity period for debtor to file plan of reorganization); Frost, supra note 4, at 93 (noting redistributive effect of Chapter 11 process).

367. See generally supra Part III.A.

368. See Charles Jordan Tabb, The Death of Consumer Bankruptcy in the United States?, 18 BANKR. DEV. J. 1, 9 (2001) [hereinafter Death] ("The consumer credit industry has been waging an almost ceaseless, relentless battle to reshape consumer bankruptcy since the mid1960s.").

369. See, e.g., Hearing Regarding S. 1301, the "Consumer Bankruptcy Reform Act of 1997, "Before the Senate Comm. on the Judiciary, 105th Cong. (1998) (statement of Randal C. Picker on behalf of National Bankruptcy Conference) (stating objections to various proposed amendments to the Bankruptcy Code relating to consumer bankruptcies), available at http://www.law.uchicago.edu/NBC/CurrentPostings/105thCongress.

370. See supra note 118 (discussing the redistributive bias of Chapter 11). 
bankruptcy lawmaking process to address policies and doctrines of general applicability, on the other hand, enormously exacerbates and widens the problem. On the legislative side, the Senate and House Judiciary Committees have jurisdiction over bankruptcy legislation. Certainly, this jurisdiction is appropriate. Bankruptcy law, including the Bankruptcy Code, is an important branch of the law of procedure and federal courts. ${ }^{371}$ But these committees and the legislative process, including interaction with the bankruptcy bar and other interest groups, generally are ill-equipped to address issues of general application that are not bankruptcy-specific.

Consider once again plant closings (including employee terminations) and priority rules dealing with conflicting claims that could arise as easily outside bankruptcy as in bankruptcy. ${ }^{372}$ A law regulating the closing of a plant and the termination of employees now falls under the jurisdiction of the Senate Committee on Health, Education, Labor \& Pensions ${ }^{373}$ and the House Committee on Education and the Workforce. ${ }^{374}$ In considering the WARN Act, ${ }^{375}$ for example, the predecessors of these committees ${ }^{376}$ took into account issues affecting firms generally. ${ }^{377}$ If the Judiciary Committees took up this topic, however, it is almost certain that the focus would be exclusively on these matters as they relate to firms that actually end up in bankruptcy. And the deliberations would be exposed to the usual redistributive biases in the process. A similar critique applies to priority rules that sort out competing claims to property. ${ }^{378}$

371. See generally supra Part III.D.

372. See generally supra Part III.A-B.

373. See U.S. Senate Comm. on Health, Education, Labor \& Pensions, About the Comm., at http://health.senate.gov/about the_committee.html (last visited June 16, 2004) (describing the matters referred to this committee).

374. See Comm. on Education and the Welfare, Full Comm. Members and Jurisdiction, at http://edworkforce.house.gov/members/108th/mem-fc.htm\#juris-fc (last visited June 16, 2004) (describing the matters referred to this committee).

375. See supra notes $127,145,146$ (discussing the applicability of WARN Act).

376. The predecessors were the Senate Committee on Labor and Human Resources and the House Committee on Education and Labor. Bartell, supra note 127, at 247.

377. See id. at 244-48 (discussing legislative history of WARN Act). Indeed, Professor Bartell notes that the Act was "not drafted with the bankrupt employer in mind." Id. at 291.

378. Fashioning a bankruptcy-only priority rule is likely to involve attention primarily to the rule's distributive effects in bankruptcy proceedings. That approach creates a high risk that insufficient consideration will be given to the rule's instrumental effects, intended or unintended, outside bankruptcy. See supra notes 171-73 and accompanying text (discussing the social costs of bankruptcy). 
Professor Edward Rubin's critique of the legislative methodology employed in the development of the federal Truth in Lending Act ${ }^{379}$ further illuminates the problem of bankruptcy-only rules in areas of general application. ${ }^{380}$ Applying "policy analysis," Rubin develops a legislative methodology that at the outset would identify a problem and the goals of legislation addressing the problem. ${ }^{381}$ Only after establishing these goals would the process proceed to consider how the goals would be implemented, the substantive elements of a solution, and the data necessary to assess various policy options. ${ }^{382}$

Consider an example. Assume that a member of Congress wishes to follow Professor Rubin's methodology. The legislator initially identifies as a problem the instances in which firms and their managers violate their fiduciary duties relating to pension plans for the firms' employees and retirees. To address the problem, the legislator then identifies two goals of new legislation. First, the legislation prevents, or makes it very unlikely, that firms and managers will violate these fiduciary duties. Second, when they are violated, the legislation ensures, or makes it substantially more likely, that the employees' and retirees' claims will be satisfied in full. In order to implement the second goal, the legislator proposes a statutory lien on all of a firm's assets. The new lien would secure claims of employees, retirees, and their pension plans arising out of these breaches of fiduciary duties. The new lien would be senior to any other liens, including preexisting liens.

The legislator next must consider relevant data. One area of inquiry, out of many, relates to the instrumental effects that would flow from putting the new statutory lien on the books. Would it adversely affect the ability of firms

379. Truth in Lending Act, Pub. L. No. 90-321, 82 Stat. 146 (1968).

380. See generally Edward L. Rubin, Legislative Methodology: Some Lessons from the Truth-in-Lending Act, 80 GEO. L.J. 233 (1991).

381. Id. at 281-89 (discussing the "Elements of Legislative Methodology"). Rubin's critique explains how the Truth-in-Lending Act embedded its principal instrumentality, disclosure, within its goals, thereby inhibiting any direct evaluation of disclosure as the instrumentality chosen to reach specific goals. Id. at 289.

382. Id. at 281-306 (discussing the "Elements of Legislative Methodology"). Professor Rubin states:

This approach .... involves a series of discrete steps: identifying the problem, defining and ranking one's goals for solving that problem, specifying all relevant options for meeting those goals, collecting the data relevant to each option, predicting the consequences of those options on the basis of the data, and then choosing the option that best achieves the goal.

Id. at 282 (citing Carl Patton \& David SAwicki, The Policy Analysis Process: Basic Methods of Policy Analysis and PlanNing 26-38 (1986); Edith Stokey \& Richard Zeckhauser, Thinking About Policy Choices: A Primer for Policy ANAlysis 5-6(1978)). 
to obtain unsecured and secured credit? Another matter to investigate would be the likely frequency and magnitude that the protected claims would arise. If these claims actually are rare, and the problem is not that serious, perhaps the new legislation is not worth the effort. On the other hand, if the claims frequently arise and present a huge problem, then the new statutory lien's potential for mischief in the financial and credit markets could be all the more problematic.

Now take another member of Congress who also worries about breaches of pension-related fiduciary duties. This second legislator, however, begins the process not with an identification of goals but with a complete bill, announced with fanfare at a press conference. ${ }^{383}$ The bill would amend the Bankruptcy Code to provide that employee and retiree claims for pension-related fiduciary breaches would have a super priority and could be satisfied even out of property subject to a valid, nonavoidable lien. This legislator's focus is on the treatment of employees and retirees in bankruptcy cases, not on the impact of the legislation on the finance and credit markets. Moreover, the second legislator's bill ignores completely the plight of employees and retirees outside the bankruptcy process, although their interests are no less worthy. The second legislator's bill has run afoul of Rubin's methodology by embedding the goal of protecting employees and retirees with the implementation strategy of a bankruptcy priority. Moreover, the second legislator is a member of a Judiciary Committee charged with overseeing bankruptcy legislation, making the legislator's strategy of implementation through bankruptcy essentially inevitable. ${ }^{384}$

The public-choice perspective on procedure theory applies not only to the legislative process but to the judicial process as well. The narrow focus on a

383. Rubin identified the flaw in this approach. See id. at 285 ("Beginning with a bill that has been fully drafted . . . virtually precludes an explicit inquiry into the bedrock goals of the legislative effort.").

384. The statement in the text presumes, as is typical, that the legislator wishes to introduce a bill that will be considered by a committee on which the legislator sits and exercises influence. Rubin also identified this concern in his critique of the Truth-in-Lending Act. Id. at 243 . He explained that the Act's principal proponent, Senator Paul Douglas, was compelled to choose the Federal Reserve Board as the Act's regulatory authority because the consequence of choosing another would have been that the subcommittee that Douglas chaired (the Senate Banking Committee's Subcommittee on Production and Stabilization) would have lost jurisdiction over the Act. Id. at 290. For a detailed discussion of the legislative history of the Truth-in-Lending Act, see $i d$. at 242-63. Truth sometimes being stranger than fiction, the second legislator's story and the substance of the bill closely approximates and is derived from the actual circumstances of the Employee Abuse Prevention Act of 2002, S. 2798, 107th Cong. (2002); Employee Abuse Prevention Act of 2002, H.R. 5221, 107th Cong. (2002). See supra note 177 (discussing the proposed legislation). 
particular debtor in bankruptcy, that debtor's creditors and shareholders, and the relevant affected employees and communities are likely to skew the application, interpretation, and development of generally applicable, nonbankruptcy-specific law. ${ }^{385}$ Even if one were to reject Frost's conclusion that the judicial process is ill-equipped to take on social engineering, such as spreading the costs of business failure, ${ }^{386}$ the courts-especially bankruptcy courts-in bankruptcy cases populated by the bankruptcy bar are inappropriate fora for resolving these problems of general application. ${ }^{387}$

The critique of bankruptcy jurisprudence - both legislative and judicialthat emerges from the public-choice account of procedure theory is consistent with a number of conventional approaches to law. Certainly the critique's emphasis on the instrumental aspect of bankruptcy law, that is too often suppressed or hidden in the process, is consistent with the ex ante economic efficiency approach favored by the law and economics school. ${ }^{388}$ The critique

385. Imagining a bankruptcy judge attempting to protect a local community from the detrimental effects of a local firm's failure through judicial discretion raises a particularly insidious specter. In the absence of a neutral principle, such as maximizing the returns for rightsholders, judges would be exposed to enormous pressure from community-based interest groups. In an analogous context, Professor Edward Zelinsky has strongly criticized the appropriateness of "economically targeted investments" (ETIs) by pension plans. Edward A. Zelinsky, ETI, Phone the Department of Labor: Economically Targeted Investments, IB 94-1 and the Reincarnation of Industrial Policy, 16 BERKELEY J. EMP. \& LAB. L. 333, 349-55 (1995) ("Particularly troubling are the possibilities of a mandatory ETI regime."). For example, Zelinsky criticized "the investment of the Connecticut state pension fund in Colt's Manufacturing Company, a large gun manufacturer and a major employer in the Hartford area." Id. at 350. As Zelinsky observed:

Connecticut treasurer Francisco L. Borges spearheaded a twenty-five million dollar investment by the state pension fund in Colt's. Four years later, Colt's was again in bankruptcy with most of the fund's money lost.

Connecticut's experience demonstrates ... in a nutshell the dangers of economically targeted investing. While Borges claimed that the Colt's venture was financially sound and that job preservation was a secondary concern, it is hard to take that argument seriously. The more compelling characterization is that Connecticut state pension monies were used for an election year bail out of a failing firm and that basic economic criteria were discounted, if not ignored.

Id. at 351 .

386. See supra notes 333-39 and accompanying text (discussing Frost's analysis of the bankruptcy process).

387. See supra note 385 (discussing the potential problem of bankruptcy judges responding to community interests).

388. See, e.g., Richard A. Posner, Economics, Politics and the Reading of Statutes and the Constitution, 49 U. CHI. L. REv. 263, 290-91 (1982) (explaining that the same influences that affect legislators should guide courts). 
also can be squared with major elements of modern legal process scholarship. $^{389}$

On one level, the public-choice account suggests that both statutory and judge-made bankruptcy-only rules and applications for areas of generally applicable law are less likely to achieve optimal results (however measured). To that extent, the critique has a utilitarian element that addresses how best to achieve "good" law. On the other hand, any critique of a process is likely to fault as well at least some of the results that the process produces. My claim here addresses primarily the judicial and legislative process.

The public-choice account of procedure theory might benefit from a closer examination of advocacy for favoring extraneous interests in bankruptcy at the expense of or risk to a debtor's rightsholders. This advocacy, whether in the Judiciary Committees of Congress, in bankruptcy or other courts, or in the pages of legal journals and books, is particularly troubling when one considers the source-bankruptcy law specialists. Returning to the plant closing example, I would enjoy as much as the next person a good argument about the pros and cons of legal doctrine that would permit unfettered plant closings and employee discharges. My views one way or another likely would be politically inspired, and my principal action on them would occur in the voting booth. Certainly, I would not hold out my views as legal scholarship without first undertaking a thorough study of the literature dealing with employment law and the relevant data in order to develop a modicum of expertise over a period of years. Now, as someone who has studied bankruptcy law, could I enhance my credibility and expertise on employment law by proposing that the argument focus solely on plant closings and the treatment of employees of firms in bankruptcy? Hardly. Yet advocates of an expansive view of bankruptcy that embraces the extraneous "employment" goal seem much less reluctant.

Interestingly, these advocates do not argue, at least not in their scholarship, for generally applicable laws that would restrict or regulate plant closings, for example. Their agenda (in this context) is limited to advocating for taking into account the employment goal in bankruptcy. ${ }^{390}$ Moreover, they make no pretense of evaluating the general social benefits of protecting employment in a market economy. Instead, as bankruptcy specialists, these advocates concentrate on an audience consisting of bankruptcy specialists. To be sure, if

389. See generally William N. Eskridge, JR. \& Philip P. Frickey, CASES AND MATERIals on Legislation: Statutes and the Creation of Public Policy (2d ed. 1995).

390. Gross certainly acknowledges this point. See Karen Gross, On the Merits: A Response to Professors Girth and White, 73 AM. BANKR. L.J. 485, 498 (1999) ("I do not aspire to change the world; I am only interested in changing a tiny corner of it, and my ambitions for change are not all that lofty."). 
they believe that regulating plant closings is good public policy, and the field of bankruptcy law is the only forum in which they have a voice, then their advocacy for the employment goal in the context of bankruptcy offers at least an opportunity to improve public policy by moving it in the "right direction." ${ }^{391}$ But that advocacy has nothing to do with bankruptcy policy or theory and certainly is not legal scholarship in the field of employment law. It represents only a second-best strategy for imposing a political judgment concerning employment law in a limited context (bankruptcy law, presumably the context in which the advocates may have influence). ${ }^{392}$

It also is worth noting that much of the impact of legitimizing the role of extraneous interests in bankruptcy would occur outside of actual litigation. Given the bargaining and negotiation context of Chapter 11, those interests would be at work in shaping the negotiations in the shadow of a potential judicial determination. ${ }^{393}$

Finally, one way to capture the public-choice account of procedure theory is to understand the linchpin of the account as distrust, along the lines of the following story. ${ }^{394}$ Insolvency is a potentially intractable problem for a market economy. An overriding federal law and federal judiciary constitute a bankruptcy system that seeks to ameliorate certain effects of insolvency, in part by following some of the injunctions of procedure theory but also in part by empowering the insolvent, whether an individual or a firm in business. Those with special influence on and power over the bankruptcy regime--legislators, judges, lawyers, and others--benefit from the bankruptcy system and the

391. I make no claim that these advocates are evil minded or wish to cause any harm. Professor Melissa Jacoby, who was senior staff attorney for the National Bankruptcy Review Commission, has observed:

[I]nstitutional and political forces, rather than some preference for different bankruptcy rules, are sometimes what put the [Judiciary] committee in a bind. They have jurisdictional problems with making fixes to other laws. Staffers often are told by others that they are fixing the wrong law when they try to make a bankruptcy-exclusive change, and they often say in response that they know, but for political and jurisdictional reasons cannot even consider changing the right law to effectuate the policy.

Memorandum from Melissa Jacoby to Charles Mooney (July 2, 2003) (on file with the Washington and Lee Law Review).

392. See infra notes 621-31 and accompanying text (making a similar argument concerning proposals for a bankruptcy-only priority rule relating to tort claimants).

393. See, e.g., Susan Block-Lieb, A Humanistic Vision of Bankruptcy Law, 6 AM. BANKR. INST. L. REV. 471, 492 (1998) ("Most bankruptcy disputes are resolved through negotiation and settlement, rather than after a trial on the merits.").

394. Much of the sentiment expressed in this paragraph draws on David Carlson's comments on an earlier draft of this paper. 
empowerment of insolvents that it delivers. They may justify the regime with utilitarian, libertarian, empirical, or other arguments. But the public-choice account warns us not to trust this regime to tinker with nonbankruptcy (mostly state) law, all in the name of their vision of the public good.

\section{Bankruptcy Law Under Procedure Theory: Consistencies and (Apparent or Real) Inconsistencies}

Procedure theory holds that the normative basis of bankruptcy law is to maximize the recoveries of and benefits for a debtor's rightsholders in accordance with nonbankruptcy law. By providing a specialized procedural body of law, bankruptcy law can enhance the recoveries and benefits of rightsholders. ${ }^{395}$ But in some cases the Bankruptcy Code modifies, even overrides, the interests and rights of rightsholders. Indeed, some restrictions on nonbankruptcy rights, such as the automatic stay, ${ }^{396}$ lie at the core of a successful procedural bankruptcy law. ${ }^{397}$ Inasmuch as procedure theory generally calls for honoring nonbankruptcy entitlements, it follows that procedure theory must take a position on these substantive modifications of nonbankruptcy rights and interests.

There are at least four strategies available for rationalizing these divergences as consistent with the goals of procedure theory. As will become apparent, these approaches are nonexclusive and overlap to some extent. First, some apparent modifications may actually be procedural, not substantive, thereby serving to provide rightsholders with the substantive benefits contemplated by nonbankruptcy law (the procedural test). Second, other apparent modifications may be generally consistent with nonbankruptcy law, or at least with policies of nonbankruptcy law (the consistency test). Third, some modifications of nonbankruptcy law, though substantive, nonetheless may serve to maximize the collective benefits for rightsholders of a debtor in financial distress in the context of a collective proceeding (the collective maximization test) ${ }^{398}$ Fourth, other modifications may supplement nonbankruptcy law when it does not provide a resolution for questions that generally arise only in a

395. See supra Part II.D (asking "Why Bankruptcy?").

396. See 11 U.S.C. \$ 362(a) (2000) (providing for the automatic stay).

397. See infra Part IV.D (discussing the automatic stay and procedure theory).

398. The collective maximization test contemplates that varying nonbankruptcy law could either increase the aggregate value available for the benefit of rightsholders or distribute value in a manner that provides greater benefits for more rightsholders. See infra note 481 (discussing pro rata distribution). 
collective proceeding concerning a debtor in financial distress (the supplemental test). Some features of current bankruptcy law cannot successfully be rationalized with procedure theory. ${ }^{399}$ Procedure theory calls for elimination or modification of those offending aspects of current bankruptcy law in order to conform bankruptcy law to procedure theory.

The remainder of this Part seeks to reconcile procedure theory with several significant features of current bankruptcy law, some of which apparently or actually modify nonbankruptcy entitlements of rightsholders. These features are (i) property of the estate, (ii) claims and interests, (iii) pro rata sharing among similarly situated rightsholders, (iv) the automatic stay, (v) the bankruptcy trustee's power to avoid certain prebankruptcy transfers, (vi) the trustee's power to reject or assume executory contracts and leases, (vii) the individual debtor's discharge and the fresh start principle, (viii) the provision for a debtor's discharge in Chapter 11, (ix) priority claims, and (x) adequate protection for undersecured creditors. These features figure prominently in the structure and operation of current bankruptcy law. Moreover, although disagreement exists as to the rationale of these features, there appears to be a general consensus as to the wisdom of most of these attributes of current law (if not as to all details). The two principal classes of rightsholders who share in or benefit from a debtor's assets are the holders of claims ${ }^{400}$ and interests ${ }^{401}$ (shareholders). For convenience, much of the following discussion focuses on the holders of unsecured claims.

One might criticize this reconciliation of procedure theory with some of the important aspects of bankruptcy law because a strict proceduralist would reject every aspect of bankruptcy law that varies any aspect of the nonbankruptcy entitlements of any rightsholder. One might also object on the basis that the rationalization undermines procedure theory to such an extent that it could accommodate even a traditionalist, redistributive approach to bankruptcy. But procedure theory accepts only variations that generally validate and benefit rightsholders. Moreover, these critiques would render bankruptcy law under procedure theory essentially identical to nonbankruptcy procedural law. Finally, as the following discussion illustrates, procedure theory finds current bankruptcy law wanting in several respects.

399. Recall that it is not necessary that a successful normative theory of bankruptcy law mirror, explain, or defend every aspect of the currently effective positive law. See supra note 11 (discussing normative theory).

400. See supra note 4 (quoting definition of "claim").

401. See supra note 244 (explaining concept of "interest" held by an "equity security holder"). 


\section{A. Property of the Estate}

The filing of a bankruptcy petition "creates an estate." 402 What constitutes "property" of the "estate" is a core concept in bankruptcy. It identifies the assets potentially available for the benefit of rightsholders in the bankruptcy case. Property of the estate includes "all legal or equitable interests of the debtor in property as of the commencement of the case." ${ }^{403}$ Federal law governs what is "property" for this purpose, and the "label" that state law provides does not control. ${ }^{404}$ But it is nonbankruptcy (usually state) law that determines the attributes of a debtor's rights or interest. ${ }^{405}$ Moreover, as interpreted by the Supreme Court in Butner v. United States, ${ }^{406}$ it is state law that creates and defines "property." 407

It is not difficult to rationalize the Bankruptcy Code's conception of property of the estate with procedure theory. Inasmuch as the property of the estate generally includes in the assets available for the satisfaction of claims the same assets that would have been available for that purpose under nonbankruptcy law, the concept is fully consistent with procedure theory and easily satisfies the consistency test. To the extent that property of the estate includes more or fewer assets, however, it could offend procedure theory. For example, if the concept were extended so as to cut off the property rights of rightsholders or third parties, as by invalidating state law liens, procedure theory could be offended. ${ }^{408}$ The same could be true if the concept were narrowed so as to deprive rightsholders of the benefits of certain of the debtor's

402. 11 U.S.C. $\$ 541(\mathrm{a})(2000)$.

403. 11 U.S.C. $\$ 541(\mathrm{a})(1)(2000)$

404. Chicago Bd. of Trade v. Johnson, 264 U.S. 1 (1924). The Court held that a seat on the Chicago Board of Trade was "property" even though applicable state law was to the contrary. Id. at 12-13. There were restrictions on the sale of the seat that were valid under state law. Id. at 7. Sale was permitted only if the proceeds were first applied to the holder's obligations to other members of the Board, which would have left nothing for the trustee in bankruptcy. $I d$. at 8 . The Court upheld the restrictions, recognizing that the rights of the trustee (and the general creditors of the debtor) were derivative of the debtor's rights. Id. at 13; see DOUGLAS G. BAIRD, ElEMENTS OF BANKRUPTCY 94-95 (3d ed. 2001); TABB, supra note 136, $\$ 5.5$, at 288-89 (discussing Chicago Board of Trade).

405. See Chicago Bd. of Trade, 264 U.S. at 14-15 (applying state law regarding membership in the Board of Trade).

406. See Butner v. United States, 440 U.S. 48, 55 (1979) ("Property interests are created and enforced by state law.").

407. See generally TABB, supra note $136, \$ 5.5$, at 287-91. For the most part the statement in the text is accurate, but a more precise statement would acknowledge that it is nonbankruptcy law that defines the property rights. That law might be state law or federal law.

408. The trustee's avoiding powers are considered in Part IV.E. 
assets that would be available under nonbankruptcy law. Dicta in Butner instructs courts not to deviate from the state law property construct "unless some federal interest requires a different result." ${ }^{409}$ Procedure theory offers a normative fence that would limit courts from an expansive application of the Butner exception. ${ }^{410}$

The Butner Court reasoned that if concepts of property applied by courts in bankruptcy varied from those outside bankruptcy it would encourage "forum shopping" and could provide a "windfall merely by reason of the happenstance of bankruptcy." ${ }^{411}$ These concerns exemplify the generally procedural nature of bankruptcy law. ${ }^{412}$ It follows that the concept of property of the estate also reflects procedure theory under the procedural test. ${ }^{413}$

\section{B. Claims and Nonclaim Entitlements}

The attributes of claims against a debtor and the identity of the holders of claims determine the "who" in the "core question of 'who gets what' in the bankruptcy distribution." ${ }^{414}$ Persons who have legal entitlements to the

409. Butner, 440 U.S. at 55.

410. Plank has addressed the constitutional limitations on the Butner federal interest exception and argued that courts are prohibited from facilitating a federal interest beyond the powers conferred by the Bankruptcy Clause. See Erie Doctrine, supra note 297, at 651-52.

411. Butner, 440 U.S. at 55. This reasoning is consistent with Plank's view that Butner is an application of the Erie doctrine. See Erie Doctrine, supra note 297, at 649-51.

412. See TABB, supra note $136, \S 5.5$, at 288 ("This explanation [by the Butner Court] is grounded in the fact that bankruptcy in large part is a procedural device utilized to distribute the debtor's property in an equitable manner to multiple creditors with competing claims."). I suspect that the Court's "windfall" from the "happenstance of bankruptcy" is much more significant in the real world than the "forum shopping" concerns.

413. Carlson strongly criticized Jackson's reliance on Butner to support what Carlson calls Jackson's "bankruptcy neutrality" principle. Philosophy, supra note 49, at 1377-78 n.117. Carlson noted that Butner's result actually was non-neutral because Butner, a mortgagee, was denied the right to collect rents for its failure to comply with a bankruptcy procedural rule. $I d$. at $1378 \mathrm{n} .117$ ("[I]t was the failure to follow a rule of bankruptcy procedure that did Butner in."). Carlson's critique appears to confound neutrality in result with neutrality in substantive nonbankruptcy law. Under the procedural test bankruptcy sometimes may, consistent with procedure theory, alter results. Otherwise the institution of bankruptcy would not be justified at all. See supra Part II.D (asking "Why Bankruptcy?"). Perhaps Carlson was concerned that the bankruptcy procedural rule that the mortgagee failed to follow (the failure to give a notice to the trustee following conversion of the case to a liquidation) was trivial (bad procedure) and unnecessarily trampled on the mortgagee's state law rights. If so, I share Carlson's concern.

414. TABB, supra note $136, \S 5.1$, at 273 . The "what," of course, is the property of the estate. Id.; see supra note 4 (quoting Chapter 11 's definition of "claim"). 
payment of money by the debtor hold claims. ${ }^{415}$ These entitlements include even a "right to an equitable remedy for breach of performance if such breach gives rise to a right to payment." ${ }^{416}$ Nonbankruptcy law governs the legal entitlements that give rise to claims. ${ }^{417}$ Only the holders of claims are entitled to share in the distribution in bankruptcy. ${ }^{418}$ At this level of generality, looking to nonbankruptcy law for the existence of legal entitlements and making distributions to the holders of those entitlements conforms to procedure theory under the consistency test.

Classifying a nonbankruptcy legal entitlement as a claim sometimes is a double-edged sword for either the debtor or the holder of the claim. Although the holder is entitled to participate in the bankruptcy distribution, the discharge granted to an individual debtor in a Chapter 7 case or to a debtor under Chapters 11,12 , or 13 operates to discharge liabilities on claims. ${ }^{419}$ Consequently, a nonbankruptcy legal entitlement that is not a claim, such as an equitable remedy for breach that does not give rise to a right to payment, is not discharged. ${ }^{420}$ Moreover, a nonclaim entitlement also is not subject to some aspects of the automatic stay. ${ }^{421}$ In the case of an individual debtor, then, the holder of the nonclaim legal entitlement can enforce its entitlement following bankruptcy; enforcement may not be stayed, and the entitlement will not be discharged. ${ }^{422}$ However, if the debtor is not an individual not only will the holder of the nonclaim entitlement receive no distribution in Chapter 7, but

415. See 11 U.S.C. \$101(5) (2000) (defining "claim").

416. 11 U.S.C. $\$ 101(5)(B)(2000)$.

417. See TABB, supra note $136, \S 7.1$, at 471 (stating that the claim must be valid under nonbankruptcy law).

418. See, e.g., 11 U.S.C. $\$ 726$ (a) (2000) (specifying the order in which claims are paid). The statement in the text assumes that the debtor is insolvent and that any equity security holders will receive nothing. Even so, in some cases even an insolvent debtor's equity security holders participate. This section focuses on the more typical situation in which only holders of claims participate in the distribution.

419. See 11 U.S.C. $\$ 727$ (b) (2000) (providing for discharge under Chapter 7); 11 U.S.C. $\$ 1141(\mathrm{~d})(1)(\mathrm{A})(2000)$ (providing that plan confirmation discharges pre-confirmation debt); 11 U.S.C. $\$ 1228$ (a) (2000) (providing for discharge under Chapter 12); 11 U.S.C. \$1328(a) (2000) (providing for discharge under Chapter 13); see also supra Part IV.G-H (discussing the individual debtor's discharge and the Chapter 11 discharge).

420. See TABB, supra note 136, $\$ 7.3$, at 477 ("The courts have been reluctant to permit debtors to use the bankruptcy discharge as a convenient way to dodge the need to comply with injunctive orders.").

421. 11 U.S.C. $\$ 362(a)(1)$ (2000) (staying judicial process to recover prebankruptcy claim), (a)(6) (staying acts to recover prebankruptcy claim); see infra Part IV.D (discussing the automatic stay).

422. See TABB, supra note 136, § 7.1, at 468-69 (discussing the effect of a creditor lacking a bankruptcy claim on an individual debtor). 
following liquidation there will be no surviving, ongoing entity against which to enforce the nondischarged entitlement-unlike the case of an individual, whose existence and whose potential for future income and assets continues. ${ }^{43}$ In Chapter 11, on the other hand, the nonclaim entitlement holder's rights will remain fully intact during and following reorganization. ${ }^{424}$

This treatment of nonclaim legal entitlements in bankruptcy generally conforms to procedure theory. Because these nondischarged and partially unstayed entitlements remain fully intact during and after bankruptcy, their status mimics precisely - indeed, is governed by - nonbankruptcy law. Even when a debtor other than an individual liquidates in Chapter 7 , leaving no viable entity following liquidation, the situation mimics nonbankruptcy law. The holder of the nonclaim entitlement is treated no differently than it would have been had the debtor simply shut down outside bankruptcy, leaving creditors to fight over the assets. Procedure theory also supports denying nonclaim entitlement holders the right to participate in bankruptcy distributions. Outside bankruptcy, nonclaim entitlement holders generally would not be entitled to recover a money judgment, otherwise they would be claims. ${ }^{425}$ Stated otherwise, limiting claims to entitlements giving rise to a right to payment makes sense under procedure theory. Bankruptcy is, at bottom, about money. Although claims in many cases are dealt with other than by cash payments, ${ }^{426}$ the essential structure of bankruptcy law demands that claims be quantified. ${ }^{427}$ As Tabb summarized:

[E]quitable remedies that cannot be satisfied under applicable nonbankruptcy law by the payment of money are not claims and are not

423. Id. (discussing the effect of a creditor lacking a bankruptcy claim on an individual debtor). Although the nonclaim entitlement will not be discharged in the case of a debtor that is not an individual, the practical effect would be the same.

424. See id., \$ 7.3, at 476-77.

425. This conclusion must be qualified somewhat. See id. $\$ 7.3$, at 481-82 (discussing In re Udell, 18 F.3d 403 (7th Cir. 1994)). Udell held that an injunctive remedy to enforce a covenant not to compete was not a claim because the liquidated damages available for noncompliance would not satisfy the injunctive remedy under nonbankruptcy law. Udell, 18 F.3d at 408 .

426. For example, Chapter 11 plans typically provide for the distribution of "property" (which could be securities such as debt instruments or stock) to the holders of claims. See, e.g., 11 U.S.C. \$1129(a)(7) (2000) ("each holder of a claim or interest . . will receive or retain under the plan on account of such claim or interest property of a value ....").

427. Quantification is necessary, for example, to calculate pro rata distributions. See infra Part IV.C (discussing pro rata sharing). It is necessary as well for purposes such as voting on a plan of reorganization. See 11 U.S.C. $\$ 1126(\mathrm{c})$ (2000) (providing that a class of creditors accepts a plan if accepted by holders of "at least two-thirds in amount and more than one-half in number of the allowed claims of such class"). 
subject to the discharge. The claimant's right to the payment of money need not be exclusive, however; as the legislative history explains, it is enough if the right to payment is alternative. The example given in the congressional explanation of the Code is a right to specific performance that can be satisfied by the payment of money in the event performance is refused.

The critical inquiry, then, is whether the nonbankruptcy law that gives rise to the equitable remedy gives the holder of that equitable remedy the right to be paid money in lieu of equitable enforcement. ${ }^{428}$

In the real world, distinguishing a claim from a nonclaim equitable remedy has been more troublesome for the courts than this straightforward reasoning might suggest. ${ }^{429}$ In particular, determining whether rights arising out of an equitable remedy constitute a claim turns on the characteristics of those rights under nonbankruptcy law. For present purposes, it is sufficient to note that procedure theory favors drawing the line that best mimics the nonbankruptcy treatment of equitable remedies. ${ }^{430}$ But this guideline must be tempered by concern for bankruptcy policies that procedure theory also would accommodate. ${ }^{431}$ In general, procedure theory supports the Bankruptcy Code's statutory framework for the treatment of claims and nonclaim entitlements for purposes of distribution, discharge, and the automatic stay.

As discussed above, only claims qualify for participation in the bankruptcy distribution scheme. But not all claims so qualify because only "allowed" claims may participate. ${ }^{432}$ A claim covered by a proof of claim $^{433}$ is deemed allowed unless an objection to the claim is made and sustained. ${ }^{434}$ Subject to

428. TABB, supra note $136, \S 7.3$, at 476 .

429. For a brief but thoughtful survey of the significant case law and discussion of the issue of what constitutes a claim arising out of an equitable remedy in the contexts of environmental laws, covenants not to compete, and specific performance, see $i d$. $\$ 7.3$. An evaluation of the case law and commentary on this issue is beyond the scope of this Article.

430. See Douglas G. Baird \& Thomas H. Jackson, Kovacs and Toxic Wastes in Bankruptcy, 36 STAN. L. REV. 1199, 1209-10 (1984) (urging an expansive view of a "claim" in bankruptcy grounded on the principle that the outcomes in bankruptcy should mimic those under nonbankruptcy law).

431. See Part IV.C (taking, for example, an overly narrow approach to when an equitable remedy is a claim impairs the underpinnings of pro rata sharing).

432. See, e.g., 11 U.S.C. $\$ 726($ a) (2000) (providing for distribution of the bankruptcy estate).

433. See 11 U.S.C. $\$ 501$ (2000) (providing for filing of proofs of claims or interests).

434. See 11 U.S.C. $\$ 502$ (a) (2000) (providing that claims are deemed allowed unless objection is made); 11 U.S.C. $\$ 502$ (b) (2000) (providing that if objection is made the court will determine the amount of the claim and allow the claim unless one of the grounds for disallowance is established). 
exceptions, only claims that exist on the date the bankruptcy petition is filed are allowed and then only in the amount of the claim on that date. ${ }^{435}$

One ground for disallowance is fundamental and fully consistent with procedure theory. A claim will be disallowed if it is unenforceable under nonbankruptcy law. ${ }^{436}$ For example, a promise might be unenforceable because it violates public policy or because the applicable statute of limitations has run under nonbankruptcy law. This ground meets the consistency test as well as the procedural test. ${ }^{437}$ Another purely procedural ground provides for disallowance of a claim if "proof of such claim is not timely filed." 438

Claims for "unmatured interest"-interest that has not accrued as of the petition date-are not allowed. ${ }^{439}$ Arguably, this practice is consistent with the allowance only of claims existing on the petition date. In effect, the existence and amount of unsecured claims, including any accrued interest, are "frozen" as of the petition date. Of course, if all unsecured claims bore interest at the same rate, whether under a contractual arrangement or at the legal rate under applicable law, the disallowance of a claim for "unmatured interest" would have no effect on the calculation of each claimant's pro rata distribution in the typical case of an insolvent debtor. But in a world where parties are free to negotiate the applicable interest rates or appeal to legislatures to enact appropriate legal rates, claimants entitled to interest outside bankruptcy should be entitled to include interest at the applicable rates as a part of their claims in bankruptcy. Procedure theory, therefore, would reject the disallowance of postpetition interest absent a showing that the burden of calculation would adversely affect rightsholders in the aggregate. ${ }^{440}$

435. 11 U.S.C. $\$ 502(b)(2000)$.

436. See 11 U.S.C. $\$ 502$ (b)(1) (2000) (providing for disallowance of a claim that "is unenforceable against the debtor and property of the debtor, under any agreement or applicable law for a reason other than because such claim is contingent or unmatured"). As to contingent and unmatured claims, see infra notes 450-55 and accompanying text.

437. See TABB, supra note $136, \S 7.5$, at 488 ("At its core, bankruptcy remains a procedural mechanism for sorting out claims that are established under nonbankruptcy law. If an entity does not have an enforceable claim against a debtor outside of bankruptcy, nothing about the debtor filing bankruptcy will change that result.").

438. 11 U.S.C. $\S 502(b)(9)(2000)$.

439. 11 U.S.C. $\$ 502(b)(2)(2000)$.

440. Some adjustments might be necessary as a matter of procedural efficiency. For example, interest could be calculated to the day of distribution of funds in a liquidation under Chapter 7 or to the date of confirmation or the effective date of a confirmed plan in the case of a reorganization under Chapter 11 . I recognize that the calculations of interest up to a specified date would impose a not insignificant expense that, as a purely practical matter, might not be worth the effort. Note also that allowing postpetition interest would not undercut pro rata sharing. It would merely calculate the accrued interest at and as of a point in time later than the petition date. 
Two additional grounds for disallowance place caps on the amount of damages that may be included in an allowed claim. One disallows a lessor's damages based on termination of a lease of real property to the extent that the damages exceed the specified cap. ${ }^{441}$ The other caps damages for termination of an employment contract. ${ }^{442}$ Because these provisions disallow damage claims that otherwise would be fully enforceable outside bankruptcy, they appear to clearly contradict procedure theory. They transfer wealth from claimants whose claims are capped to other claimants. There may, however, be a coherent bankruptcy justification for these caps. ${ }^{43}$ In the case of both real property leases and employment contracts, aggrieved lessors and employees seeking damages may be under a duty to mitigate their damages. ${ }^{444}$ Allowing these claimants full, uncapped recoveries subject to their mitigation duties arguably could impose unacceptable delay in a bankruptcy case. Therefore, the argument goes, the caps would be justified on the basis of administrative convenience in the bankruptcy process. ${ }^{445}$

Because in general only claims existing on the bankruptcy petition date may be allowed, it is necessary to determine when a claim arises for bankruptcy purposes and to determine the amount of the claim. A claim may be "contingent" or "unliquidated." ${ }^{446}$ An example of the former would be the obligation of an applicant on a letter of credit to reimburse the issuer of a letter of credit if the beneficiary draws on the credit. ${ }^{447}$ The applicant must reimburse

441. 11 U.S.C. $\$ 502(b)(6)(2000)$.

442. 11 U.S.C. $\$ 502(b)(7)(2000)$.

443. Tabb acknowledges this wealth transfer. See TABB, supra note 136, $\$ 7.5$, at 489 ("In effect, then, $\$ 502(b)(6)$ redistributes some of the uncertain entitlement of the real estate lessor to other creditors."). He candidly explains its rationale: The cap on a lessor's damages is "to prevent that claim from consuming a disproportionately large share of the estate, to the detriment of other creditors." Id. In a just and coherent system, the lessor would receive a "disproportionate" share only if under nonbankruptcy law and the lease agreement the lessor were entitled to that "disproportionate" share based on a disproportionately large claim.

444. See Roger A. Cunningham et Al., The LaW of Property $\$ 6.82$, at 408 (2d ed. 1993 ) (noting that many states provide tenants with a defense to payment of rent unless landlord makes a reasonable attempt to re-lease for the tenant's account in order to mitigate damages); RESTATEMENT (SECOND) OF CONTRACTS § 350(1) (1979) ("[D]amages are not recoverable for loss that the injured party could have avoided without undue risk, burden or humiliation.").

445. This rationale does not fully explain why contract claims generally are not capped, inasmuch as a duty of mitigation is a generally applicable principle of contract law. See RESTATEMENT (SECOND) OF CONTRACTS \$ 350(1) (1979) ("[D]amages are not recoverable for loss that the injured party could have avoided without undue risk, burden or humiliation."). One response is that real property leases, especially, and employment contracts, perhaps, often are of a very long duration.

446. See 11 U.S.C. $\$ 101(5)$ (2000) (defining "claim").

447. See, e.g., U.C.C. $\$ 5-108(i)(1)$ (2000) (providing the obligation of an applicant to 
the issuer if the credit is drawn on and honored, but if the applicant files a bankruptcy petition before that time its obligation is contingent-it is possible that the credit will never be drawn on and honored. An example of the latter is a tort claim that has not yet been reduced to judgment against the debtor (and thereby liquidated). The tort claim also may be "disputed" by the debtor but would be a "claim" nonetheless. ${ }^{48}$ The court must estimate claims for allowance purposes in two situations: If the claim is contingent or unliquidated, otherwise the administration of the case would be "unduly delay[ed]," and if the claim is based on "an equitable remedy for breach of performance."

The allowance of contingent claims and the estimation of contingent and unliquidated claims and those arising out of equitable remedies are deviations from nonbankruptcy law. Outside bankruptcy, an unmatured and contingent claim generally would not be ripe for the commencement of a civil action. ${ }^{450}$ In addition, a court outside bankruptcy would adjudicate claims as opposed to estimating them, estimation being a somewhat rougher form of justice. ${ }^{451}$ But in the case of both unmatured and contingent claims, prebankruptcy events have given rise to a set of legal relationships, even thought they are not yet ripe for obtaining a judicial remedy under nonbankruptcy procedural law. Thus allowing unmatured and contingent claims in bankruptcy generally are deviations from nonbankruptcy procedural law (with a decidedly substantive impact, of course). As such, these deviations are consistent with procedure theory under the procedural test. A narrower conception of allowable claims resolution, more closely resembling nonbankruptcy civil procedure, would not serve as well the need for a collective bankruptcy proceeding to deal with

reimburse the issuer of a letter of credit).

448. See 11 U.S.C. $\$ 101(5)$ (2000) (defining "claim"). Of course, if it turns out that the debtor has no liability, then the claim will be disallowed. The bankruptcy court has jurisdiction to determine the validity of a claim other than one for "personal injury tort or wrongful death." 28 U.S.C. $\$ 157$ (b)(1), (2)(B) (2000).

449. 11 U.S.C. $\$ 502(\mathrm{c})$ (2000); see supra notes 425-31 and accompanying text (discussing rights to payment arising from equitable remedies).

450. Consider the example of a contingent reimbursement claim against the applicant held by the letter of credit issuer. Until that claim matures, and assuming no dispute between the issuer and the applicant, there would be no case or controversy on which a civil action-even one for declaratory relief - could be brought. See, e.g., JAMES \& HAZARD, supra note 14, $\$ 1.10$, at 26-30 (discussing "case or controversy" requirement for declaratory relief).

451. This estimation is especially rough when a claim with a positive value is valued at zero because the probability of success, in the case of a disputed unliquidated claim, is less than fifty percent. See, e.g., Bittner v. Borne Chem. Co., 691 F.2d 134, 136-37 (3d Cir. 1982) (rejecting the "probability of success" method in favor of the "ultimate merits" method of estimation and valuing claims at zero when the probability of success was less than $50 \%$ ). Jackson criticized Bittner because its reasoning "skew[s] nonbankruptcy values." JACKSON, supra note 70, at 46-47. Procedure theory sides with Jackson. 
financial distress. Whether in contexts such as an individual debtor's discharge ${ }^{452}$ or the restoration of a corporation to viability under Chapter $11,{ }^{453}$ it is crucial that the bankruptcy proceeding address as broad a range of the debtor's financial affairs as feasible, in the absence of a good reason to the contrary. ${ }^{454}$ The broad scope of allowable claims and the estimation process invoke in bankruptcy the aphorism "it's now or never." 455

This same reasoning supports an expansive view of the time that a claim comes into existence for bankruptcy purposes. While nonbankruptcy law determines the question whether a legal entitlement exists, in a collective proceeding, federal bankruptcy law must determine the time that a claim arises for bankruptcy purposes. The narrowest approach would limit claims to those that actually have accrued and on which actions could be brought under applicable nonbankruptcy law (the so-called "accrued state law claim test"). ${ }^{456}$ The accrued state law claim test would disqualify from participation in the bankruptcy process a large range of potential claimants whose fullblown causes of action might accrue in the future based on the debtor's prebankruptcy conduct and the potential claimant's prebankruptcy relationships with the debtor. As already noted, that would unduly weaken bankruptcy as a collective procedural mechanism. ${ }^{457}$ The most expansive plausible approach would include as claims any existing or subsequent obligation or liability arising out of the debtor's prebankruptcy conduct (the so-called "conduct test"). ${ }^{458}$ Applied strictly, however, the conduct test could

452. See infra Part IV.G (discussing the individual debtor's discharge).

453. See supra Part II.D (discussing rationale for bankruptcy law).

454. See TABB, supra note $136, \$ 7.4$, at 486 ("In keeping with the basic policy decision to resolve all of the debtor's legal obligation in the bankruptcy case, even unliquidated and contingent claims must be estimated and then dealt with in the bankruptcy proceeding."). A reason to deviate from this policy can be found in the exclusion from the definition of "claim" equitable remedies that cannot be reduced to a quantified right to payment under nonbankruptcy law. See supra notes 425-31 and accompanying text (discussing discharge).

455. This is not to say that the allowance process as it exists under the Bankruptcy Code and applicable case law is perfect and could not be refined usefully by a close examination employing procedure theory's tenets. But my claim here is that procedure theory can accommodate a procedural structure in bankruptcy generally along the lines of current law.

456. See Epstein v. Official Comm. of Unsecured Creditors of Piper Aircraft Corp., 58 F.3d 1573, 1576 (11th Cir. 1995) (describing the "accrued state law claim test"). As the court in Piper explained, the principal case supporting the accrued state law claim test is In re Frenville Co., 744 F.2d 332 (3d Cir. 1984). Piper declined to follow Frenville. Piper, 58 F.3d at 1576 n.2.

457. See supra notes 452-55 and accompanying text (discussing discharge).

458. See Grady v. A.H. Robins Co., 839 F.2d 198, 201 (4th Cir. 1988) (declining to follow Frenville). 
discharge "claims" in which no damages have arisen or have been discovered until long after the bankruptcy case had been closed. ${ }^{459}$ A strict conduct test could make it impossible to know about, much less administer, a collective proceeding inasmuch as holders of many claims could not participate even though their claims would be discharged. The proper test for when claims exists must, then, balance the need for a broadly applicable collective bankruptcy system with the administrative burdens and procedural unfairness that an overly expansive test would entail.

The court in Epstein v. Official Comm. of Unsecured Creditors of Piper Aircraft Corp. sought to strike such a balance. ${ }^{460}$ The Piper court described the appropriate test -in a products liability context-as follows:

[A]n individual has a $\S 101(5)$ claim against a debtor manufacturer if (i) events occurring before confirmation create a relationship, such as contact, exposure, impact, or privity, between the claimant and the debtor's product; and (ii) the basis for liability is the debtor's prepetition conduct in designing, manufacturing and selling the allegedly defective or dangerous product. The debtor's prepetition conduct gives rise to a claim to be administered in a case only if there is a relationship established before confirmation between an identifiable claimant or group of claimants and that prepetition conduct. ${ }^{461}$

Procedure theory accepts this sort of balance under the procedural, collective maximization, and supplemental tests. But procedure theory could accept any of the three tests or variations on any of them. ${ }^{462}$

\section{Equal Treatment for Similarly-Situated Rightsholders: Pro Rata Sharing}

Pro rata sharing in bankruptcy also fits well within the consistency, collective maximization, and supplemental tests for rationalizing current

459. See Lemelle v. Universal Mfg. Corp., 18 F.3d 1268, 1278 (5th Cir. 1994) (holding that "claim" did not include rights of persons injured two years after Chapter 11 plan was confirmed and who "were completely unknown and unidentified at the time Winston filed its petition and whose rights depended entirely on the fortuity of future occurrences"). In Robins, by contrast, the first symptoms of the injuries giving rise to the claim at issue were observed after the bankruptcy petition was filed but on the same day. Robins, 839 F.2d at 199.

460. See Piper, 58 F.3d at 1577 (outlining the new Piper test to determine the "scope of the term claim").

461. Id.

462. A complete analysis of the appropriate test for when a claim comes into existence is beyond the scope of this paper. For present purposes, the point is that procedure theory could accommodate a broader concept of a claim than the accrued state law claim test. 
bankruptcy law with procedure theory. To some extent, it also can be rationalized under the procedural test. As is well known and commonly accepted, unsecured creditors share pro rata in distributions under the Bankruptcy Code. ${ }^{463}$ At first blush, pro rata sharing appears to contradict nonbankruptcy law and policy. Under nonbankruptcy law, unsecured creditors have no property interest in their debtor's assets until such time as they receive a judicial lien, normally following judgment and, as to personal property, the exercise of judicial remedies against the debtor's assets. ${ }^{464}$ Priorities generally date from the time that the judicial liens are created. ${ }^{465}$ This "first-in-time" principle has become known as the "race of diligence" or "grab rule." ${ }^{466}$ As discussed above in connection with the procedural benefits of a collective proceeding, through the mechanism of pro rata sharing, bankruptcy stops this race short and puts on an equal footing all unsecured creditors who have not obtained judicial liens. ${ }^{467}$ On this analysis, then, pro rata sharing trumps nonbankruptcy law's race of diligence and thereby conflicts with nonbankruptcy law and its principles. But that analysis and its conclusion are flawed.

In circumstances where pro rata sharing is feasible, nonbankruptcy law historically and consistently has employed (or, at least, taken into account) pro rata sharing to allocate scarce resources among similarly-situated persons. ${ }^{468}$ Examples are state law assignments for the benefit of creditors, ${ }^{469}$ creditors'

463. See 11 U.S.C. $\$ 726(a)(2)$ (2000) (providing for payment of unsecured, timely filed claims); TABB, supra note 136, $\$ 7.7$, at 494 (discussing the "equality of distribution" among general unsecured creditors). The principal exceptions are priority claims under 11 U.S.C. $\$ 507$ (a) (2000). See infra Part IV.I (discussing priority claims and procedure theory). Priority claimants of a particular class, however, share pro rata when there are insufficient assets to satisfy all of the priority claims of that class. 11 U.S.C. $\$ 726$ (b) (2000).

464. See generally Stefan A. Riesenfeld, Creditors' Remedies and Debtors' PROTECTION 4-239 (4th ed. 1987).

465. See id. at 151-63 (discussing the "Commencement and Priority of Lien").

466. See JACKSON, supra note 70, at 8-9 ("Creditor remedies outside of bankruptcy (as well as outside other formal, nonbankruptcy collective systems) can be accurately described as a species of 'grab law,' represented by the key characteristic of first-come, first-served.").

467. See supra notes 93-97 and accompanying text (discussing the pooling of assets for the benefit of all creditors).

468. David Carlson has taken note of this circumstance. See Philosophy, supra note 49, at 1355 n.43 ("My interpretation [of equality of creditors] does not go to the phenomenon of federal bankruptcy, but rather to the idea of creditor equality in any kind of collective proceeding.").

469. Although state statutes and interpretations of common-law assignments vary, equality of treatment of creditors plays an important role in many jurisdictions. See generally RIESENFELD, supra note 464, at 439-41. 
bills, ${ }^{470}$ and receiverships, including equity receiverships, under both state and federal law. ${ }^{471}$ The law of decedents' estates also applies a pro rata sharing approach to heirs of a particular residual class under state law rules of descent and distribution, ${ }^{472}$ as well as to claims of creditors in the case of insolvent estates. ${ }^{473}$ There are other examples of systems for sharing that, while not pro rata, are likewise intended to achieve equity, if not strict equality. ${ }^{474}$

Nonbankruptcy law embraces pro rata sharing, both as a doctrine and as a normatively superior approach. And for good reason. Equal treatment under the law has a significant moral claim and acceptance. We expect there to be a good reason, instrumental or otherwise, for the law to favor one claimant over another. ${ }^{475}$ Why, then, does nonbankruptcy law opt for a baseline first-in-time rule embodied in the race of diligence? The answer is not that nonbankruptcy law favors a first-in-time rule, and it is left to bankruptcy law to straighten

470. See John W. Smith, The Equitable Remedies of Creditors \$ 239, 247-48 (1899) (discussing the rule establishing priority for the plaintiff in creditor's bills, specifically its inapplicability when a junior judgment creditor files a bill on its behalf and on behalf of all creditors who prove claims); Hutchinson, supra note 93, at 464 (stating that in a creditors' bill filed against an insolvent debtor, "[e]quity found the alternative to class treatment unacceptable: giving a court-sanctioned preference to the creditor that won the race to the courthouse").

471. See generally RIESENFELD, supra note 464, at 452-53.

472. See UNIF. Probate CODE $\$ 2-106$ (amended 1990), 8 U.L.A. 282 (1998) (describing the shares allocated to descendants of the same class).

473. 31 AM. JUR. 2D Executors and Administrators $\$ 833$ (2002) ("Claims of creditors of the same class against a decedent are, in case of insolvency of his estate, to be paid pro rata.").

474. See, e.g., Jackson \& Scott, supra note 74, at 171-74 (discussing the "general average contribution" doctrine for "common disaster" in admiralty law); Robert J. Aumann \& Michael Maschler, Game Theoretic Analysis of a Bankruptcy Problem from the Talmud, 36 J. ECON. THEORY 195, 195-96 (1985) (describing the Talmudic distributional system under which, if creditors are owed 100,200, and 300, and there is (i) 100 to distribute, each creditor receives 33.33, (ii) 200 to distribute, the first creditor receives 50 and the second and third receive 75 , and (iii) 300 to distribute, the first creditor receives 50 , the second receives 100 , and the third receives 150 ).

475. The fact that almost everyone agrees on the baseline principle of pro rata sharing, even if their reasons may diverge, provides strong support for the statement in the text. Karen Gross argues for a gloss on the principle, calling for "equal outcomes" generally based on pro rata treatment but not necessarily "equal treatment." GROSS, supra note 9, at 165-76. Under her scheme, a creditor who, for example, would lose its home if required to accept a bankruptcy distribution over an extended period might be paid in full early on. Id. at 165 . A "deep pocket" creditor, on the other hand, could be required to wait for extended payments. Id. at 166 . Even this proposal for a modification of the approach of equal treatment evoked strong rebukes. For thoughtful and persuasive reviews of this aspect of Gross's book, see Alces, supra note 131, at 391-95 (discussing the inappropriateness of laying burdens upon large creditors) and White, supra note 131, at 442-47 (criticizing the proposal to transfer wealth from wealthy creditors to poor creditors). 
things out (equity is equality and all that). ${ }^{476}$ To the contrary, nonbankruptcy law should not be understood to hold that the first-in-time judicial lienholder is more deserving than a later-in-time party. It should not be understood to value more highly the satisfaction of the earlier party's claim. The strong and clear message of the overarching pro rata sharing rule under nonbankruptcy law makes this clear.

The answer to the question posed must be that the first-in-time principle is the only feasible approach under nonbankruptcy law in a garden-variety noncollective proceeding for the judicial enforcement of a substantive legal entitlement. To impose a requirement that every judicial enforcement of a claim necessitates a collective proceeding in order to apply a pro rata sharing rule would cripple the process. ${ }^{477}$ In a legal system that recognizes private claims and private judicial enforcement, a judgment creditor must have a means to reach a debtor's assets. And, as explained above, without effective procedural law-including effective remedies-substantive legal entitlements are diminished, if not destroyed. ${ }^{478}$ The first-in-time rule for judicial lien creditors is the only feasible general approach to the procedural enforcement of legal rights. Moreover, unless a judgment debtor is insolvent, there is a de facto pro rata sharing because every claimant ultimately can be satisfied. When nonbankruptcy law addresses circumstances in which there are insufficient assets to satisfy similarly-situated claimants, such as insolvency, it opts for pro rata sharing. The foregoing demonstrates that one can reconcile bankruptcy law's pro rata sharing rule with procedure theory under the consistency approach. ${ }^{479}$

Reconciliation also is possible under the collective maximization approach. It is true enough that some individual creditors might recover less under bankruptcy law's pro rata sharing approach than under the race of diligence. For example, a creditor might argue that it was in a commanding position to recover through judicial enforcement much earlier than any other

476. See JACKSON, supra note 70, at 9-19 (discussing the interaction between nonbankruptcy and bankruptcy law).

477. Short of imposing a collective regime for every judicial enforcement, one might imagine a scheme involving judicial discretion. But that would likely result in a discriminatory and time-consuming process. I thank Stephen Burbank for making this observation.

478. See supra Part II.B.1 (discussing "Bankruptcy as Civil Procedure").

479. Of course, as explained in Part II.D, one virtue of a collective proceeding is that the aggregate value produced and preserved may be increased. But that factor is simply part of the case for a collective proceeding and does not necessarily bear on the question of pro rata sharing. See Philosophy, supra note 49, at 1351 ("Jackson has erroneously connected the existence of bankruptcy efficiencies with the institution of creditor equality. The two have no logical connection whatsoever."). 
creditor. ${ }^{480}$ On the other hand, for a collective group in a collective proceeding, pro rata sharing can produce the result that a larger number of a debtor's creditors would receive a larger amount, although pro rata sharing does not affect the aggregate value available for distribution. ${ }^{481}$ Inasmuch as nonbankruptcy law does not value one claim higher than another, viewed in this light pro rata sharing provides a greater collective benefit.

Pro rata sharing also may be reconciled with procedure theory under the supplemental approach. As an important feature of a collective proceeding, pro rata sharing supplements nonbankruptcy law's first-in-time system in which sharing would not be feasible. Stated otherwise, because nonbankruptcy law reflects no generalized priority rule among unsecured creditors, pro rata sharing supplements nonbankruptcy law by declaring a "tie."

Finally, pro rata sharing possesses further supplemental and procedural components. Bankruptcy law must adopt some method for applying the value of the debtor's assets to the interests of rightsholders in order to achieve its ends. While this explanation does not necessarily point to pro rata sharing, as opposed to some other allocative method, it does identify a justification for departing from (or, more accurately under the supplemental test, supplementing) nonbankruptcy law. Under another procedural conceptualization, the trustee in bankruptcy figuratively obtains a de facto judicial lien for the benefit of all the unsecured creditors. ${ }^{482}$ That understanding would comport with the race of diligence under nonbankruptcy

480. This position might be hard to prove in many cases. See BAIRD, supra note 404, at 81 ("The rule of pro rata distribution provides a way to approximate the rights of each of the general creditors. ... [W] have the pro rata sharing rule because trying to answer arguments like these [about likely outcomes of creditor recoveries outside bankruptcy] is more trouble than it is worth."). I ignore, for now, the possibility that the judicial lien could be avoided as a preference. See 11 U.S.C. $\$ 547$ (b) (2000) (providing the trustee's preference avoidance powers); see also infra Part IV.E.2 (discussing bankruptcy preferences).

481. Consider an example. A debtor has $\$ 100$ in assets and four creditors, owed respectively $\$ 100, \$ 35, \$ 25$, and $\$ 10$. Assume that outside bankruptcy the $\$ 100$ creditor could have reached the assets and satisfied itself in full. That would result in an average per creditor percentage of the claims paid of $25 \%(\$ 100+0+0+0=\$ 100 / 4$ creditors $=25 \%)$. Applying a pro rata sharing approach, each claimant would receive a distribution of $59 \%(\$ 100 / \$ 170=$ $59 \%$ ). I do not claim that the distributional features of bankruptcy law alone serve to increase aggregate value. James Bowers has asserted a very different view. See Murphy's Law, supra note 77 , at 2143-44 (arguing that the distributional scheme affects creditors' losses and that non-pro rata distributions can reduce losses).

482. See Organizing Principle, supra note 79, at 622--23 (discussing the trustee's "strongarm power" under 11 U.S.C. $\$ 544(\mathrm{a})(1)$, under which the trustee receives the status of a hypothetical judicial lien creditor, is an "organizing principle" of bankruptcy law). The "strongarm power" and other avoiding powers of the trustee are addressed in Part IV.E. 
law inasmuch as the judicial lien for the benefit of each creditor would arise simultaneously upon the bankruptcy filing.

\section{Automatic Stay}

Upon the filing of a bankruptcy petition, Section 362 of the Bankruptcy Code imposes an automatic stay-a statutory injunction, in effect. ${ }^{483}$ The automatic stay plays a "core role" in bankruptcy ${ }^{484}$ and is "[a]n integral structural component of a bankruptcy case. "185 It stays a host of acts that would disrupt an orderly bankruptcy process, such as the commencement or continuation of judicial or other actions or proceedings, ${ }^{486}$ enforcement of judgments against the debtor or the debtor's property, ${ }^{487}$ acts to "obtain possession of property of the estate," ${ }^{488}$ and the creation, perfection, or enforcement of liens on property of the estate. ${ }^{489}$ Broad as it is, the automatic stay is not absolute. Several acts that otherwise would be covered by the stay are excepted. ${ }^{490}$

The automatic stay protects both the debtor and creditors by preserving the status quo. It supplements and complements the rationale for a special wealth preservation (or enhancing) bankruptcy proceeding. It links property of the estate, claims against the debtor, and the baseline rule of pro rata sharing. ${ }^{491}$ In general, the automatic stay permits an orderly and properly structured bankruptcy process to work for the benefit of the debtor and rightsholders and meets the procedural, collective maximization, and supplemental tests.

In proper circumstances, a party in interest may obtain relief from the automatic stay. Consistent with procedure theory, the grounds for relief are designed to protect the interests of persons other than the debtor, and

483. 11 U.S.C. $\$ 362$ (a) (2000).

484. See BAIRD, supra note 404 , at 169 (stating that the "core rule" is the automatic stay's ability to "stop individual creditors from taking actions that would thwart the reorganization and to allow the debtor to continue doing business with the rest of the world on ordinary terms").

485. TABB, supra note $136, \S 3.1$, at 146 .

486. 11 U.S.C. $\$ 362(\mathrm{a})(1)(2000)$.

487. 11 U.S.C. $\$ 362(a)(2)(2000)$.

488. 11 U.S.C. $\$ 362(a)(3)(2000)$.

489. 11 U.S.C. $\$ 362(a)(4)(2000)$.

490. See 11 U.S.C. $\$ 362$ (b) (2000) (providing exceptions).

491. See BAIRD, supra note 404, at 169 ("[The automatic stay] stop[s] individual creditors from taking actions that would thwart the reorganization and to allow the debtor to continue doing business with the rest of the world on ordinary terms .... Allowing creditors to take action during the bankruptcy proceeding would undermine bankruptcy's pro rata sharing rule."). 
appropriately applied, they inhibit the automatic stay from a redistributive effect. ${ }^{492}$ If improperly applied, however, the stay can conflict with procedure theory by impairing a rightsholder's nonbankruptcy entitlements for the benefit of other rightsholders or third parties. ${ }^{493}$

\section{E. Trustee in Bankruptcy's Avoiding Powers}

Several provisions of the Bankruptcy Code confer on the trustee in bankruptcy the power to "avoid"— set aside - transfers of property made by the debtor before a bankruptcy filing. An avoidance has the effect of making the transferred property available as a source of value for distribution to the debtor's rightsholders. ${ }^{494}$ In addition to the avoiding powers of the trustee, Section 365 of the Bankruptcy Code permits the trustee to "reject"-elect not to be bound by - executory contracts and leases. ${ }^{495}$ That section also permits the trustee to "assume"- elect to become bound by and preserve - these contracts and leases, in some cases under circumstances in which the debtor could not preserve the contract or lease under nonbankruptcy law. ${ }^{496}$ As with pro rata sharing, these provisions appear to contravene nonbankruptcy law and to upset the nonbankruptcy entitlements of rightsholders. To a great extent, however, the avoiding powers actually derive from and are closely connected to nonbankruptcy law. This section and the following section explain how procedure theory can accommodate in principle, if not in every detail, both the avoiding powers and the regime for rejection and assumption of executory contracts and leases.

\section{Strong-Arm}

Under the "strong-arm" avoiding power, the trustee in bankruptcy has the rights and powers of a hypothetical judicial lien creditor as well as the rights of

492. See 11 U.S.C. $\$ 362(d)(1)$ (2000) (providing relief to be granted "for cause, including the lack of adequate protection"); 11 U.S.C. $\$ 362(\mathrm{~d})(2)$ (2000) (providing relief to be granted as to acts against property when "the debtor does not have an equity in the property" and the "property is not necessary for an effective reorganization").

493. See infra Part IV.J (discussing adequate protection for secured creditors).

494. Property of the estate includes property recovered by the trustee's exercise of its avoiding powers. 11 U.S.C. $\$ 541$ (a)(3) (2000).

495. 11 U.S.C. $\$ 365$ (a) (2000).

496. 11 U.S.C. $\$ 365(a)-(b)(2000)$. 
a bona fide purchaser of real property. ${ }^{497}$ By exercising the strong-arm power, the trustee can avoid prebankruptcy transfers, including security interests and other liens, that would be subject to the rights of a judicial lien creditor under applicable nonbankruptcy (normally, state) law. In the most practically significant context, the trustee may use its strong-arm power to avoid the creation of a prebankruptcy security interest in personal property or fixtures if the security interest is unperfected at the time of the bankruptcy filing. ${ }^{498}$ The metaphor of the trustee as a judicial lien creditor for the benefit of the creditors generally embraces the strong-arm power. ${ }^{499}$ It preserves the benefits of applicable nonbankruptcy law that, absent bankruptcy, would have been available for unsecured creditors that could have obtained judicial liens against, for example, collateral subject to an unperfected security interest. In effect, the strong-arm power interrupts the nonbankruptcy race of diligence, thereby declaring a "tie" as among the unsecured creditors and freezing the status of an unperfected security interest as such. ${ }^{500}$ By this operation, it subordinates the unperfected security interest to the trustee's rights for the benefit of the creditors generally, thereby complementing the pro rata sharing rule. ${ }^{501}$

By mimicking nonbankruptcy law in the context of a collective proceeding, the strong-arm power is fully consistent with procedure theory. Because it complements the pro rata sharing rule and gives effect in bankruptcy to the nonbankruptcy rights of a hypothetical judicial lien creditor, the strongarm power may be reconciled with procedure theory on essentially the same rationale applicable to pro rata sharing. ${ }^{502}$

497. See 11 U.S.C. $\$ 544(a)(1)$ (2000) (granting the trustee the powers of a hypothetical judicial lien creditor); 11 U.S.C. $\$ 544(a)(3)$ (2000) (granting the trustee the powers of a "bona fide purchaser of real property").

498. See U.C.C. \$ 9-317(a)(2) (1999) (providing that an unperfected security interest in personal property or fixtures is subordinate to a lien creditor unless one of the conditions specified in U.C.C. $\$ 9-203(b)(3)$ is satisfied, such as a debtor authenticating a security agreement, and a financing statement has been filed); U.C.C. \$9-102(a)(52) (1999) (defining "lien creditor").

499. See supra note 485 and accompanying text (discussing this metaphor in the context of a procedural justification for pro rata sharing).

500. See TABB, supra note 136, $\$ 6.5$, at 338-39 (1997) (discussing the effect of the strongarm power on unsecured creditors).

501. Indeed, Carlson identifies the trustee's strong-arm power as the organizing principle of bankruptcy. Organizing Principle, supra note 79, at 622-23. Carlson also points out that notwithstanding the avoidance paradigm, in actuality unperfected security interests are merely subordinated to the extent necessary to satisfy unsecured creditors, although it is avoided once the collateral is disposed of by the trustee. See id. at 559-62 ("[S]ubordination is avoidance, and avoidance is subordination.").

502. See supra Part IV.C (discussing pro rata sharing); see also Policy, supra note 40, at n.48 (discussing the strong-arm power and pro rata sharing). The Policy text states: 


\section{Preferences}

The power of the trustee in bankruptcy to avoid preferences is quite unlike the trustee's strong-arm power. In particular, it does not derive generally from nonbankruptcy law. ${ }^{503}$ The trustee-as-judicial-lienholder metaphor does not hold. Indeed, as Professor Carlson has put it, voidable preference law "strikes at transactions that are perfectly legal and even admirable at state law. Voidable preference law undoes payment and security of debt." ${ }^{504}$ Following is a description of the generally proffered justifications for voidable preference law, followed in turn by an explanation of how preference law generally comports with procedure theory.

Voidable preference law is codified in Bankruptcy Code Section $547 .^{505}$ It provides for the avoidance of certain prebankruptcy transfers of the debtor's property "to or for the benefit of a creditor" or "on account of an antecedent debt." ${ }^{506}$ A transfer is voidable only if it is made while the debtor is insolvent and within ninety days before the date that the debtor's bankruptcy petition is filed. ${ }^{507}$ In addition, to be voidable a transfer must allow the creditor to obtain more than it would have obtained in a Chapter 7 liquidation of the debtor had

An involuntary bankruptcy is conceptually very much like a collective judicial lien, in that the bankruptcy court takes jurisdiction over the debtor's property for the purpose of using it to satisfy claims. See 11 U.S.C. $\$ 303$ (addressing filing of involuntary cases). Giving the trustee this same status in a voluntary case eliminates any costly manipulation and perverse incentives concerning the filing of a voluntary as opposed to an involuntary case. This metaphor fits less comfortably with the trustee's "strong-arm" power for transfers of real property, as to which the trustee has the rights of a hypothetical bona fide purchaser, not merely the rights of a judicial lien creditor. $I d$. at $\$ 544(\mathrm{a})(3)$. The real-property "strong-arm" power is best viewed as an anti-secret lien policy that is more exacting than state law. See THOMAS H. JACKSON, THE LOGIC AND LIMITS OF BANKRUPTCY LAW $76 \&$ n. 13 (1986) (explaining that drafters of Bankruptcy Code "appear to have concluded that the trustee's strong-arm power principally addressed the evil of property interests with ostensible ownership problems that remained despite available curative measures under nonbankruptcy law").

Id.

503. Some states also have preference laws, however. See, e.g., 39 PA. CONS. STAT ANN. $\$ 151$ (West 1954) (addressing "preferences inuring to the benefit of all creditors").

504. Crucible, supra note 268 , at 213 .

505. See 11 U.S.C. $\$ 547$ (2000) (establishing the trustee's preference avoidance powers). For a classic discussion, see generally Vern Countryman, The Concept of a Voidable Preference in Bankruptcy, 38 VAND. L. REV. 713 (1985).

506. 11 U.S.C. $\$ 547(\mathrm{~b})(1)-(2)(2000)$.

507. 11 U.S.C. $\$ 547($ b)(3)-(4)(A) (2000). If the creditor was an insider, avoidable transfers include those made "between ninety days and one year before the date of the filing of the petition." 11 U.S.C. $\$ 547(\mathrm{~b})(4)(\mathrm{B})(2000)$. 
the transfer not been made and had the creditor received its distribution in the Chapter 7 proceeding. ${ }^{508}$

Payment of a preexisting debt is a classic example of an avoidable preference. Assume that a creditor is owed $\$ 100$ by an insolvent debtor and that in a Chapter 7 liquidation of the debtor the creditor would receive a distribution equal to $10 \%$ of its unsecured claim or ten dollars. If the debtor were to make a payment to the creditor, whether partial or in full, the creditor would receive payment on a dollar-for-dollar basis to the extent of the payment made, leaving the remaining balance (if any) on the debt as an unsecured claim in a Chapter 7 liquidation. Payment of any portion of the debt on a dollar-fordollar basis necessarily gives the creditor more than it would obtain (hypothetically, 10\%) in the debtor's Chapter 7 liquidation. In fact, in any case in which the creditor would not receive $100 \%$ of its claim in the Chapter 7 , any prepetition payment necessarily allows the creditor to improve its position over that which the creditor would obtain in the debtor's Chapter 7. Inasmuch as providing the creditor with collateral for an antecedent debt before the petition is filed also would allow the creditor to obtain the collateral value on a dollarfor-dollar basis in the Chapter 7, a prepetition grant of collateral for antecedent debts also can be avoided under Section 547.

The flip side of voidable preference law is the effect of a prepetition transfer on the debtor's other, nonpreferred creditors. To the extent that the debtor's assets are depleted before the bankruptcy petition is filed to satisfy a creditor's debt, they are unavailable in the Chapter 7 liquidation to satisfy a portion of the other creditors' claims. Hence, the creditor that benefits from the prepetition transfer is said to have been preferred to the detriment of the other creditors. Voidable preference law, then, reverses the preference and brings the assets back into the debtor's estate for the benefit of all creditors, who will share pro rata in the recovered assets.

There are two principal accounts for the purpose of voidable preference law. The first is deterrence. Because a creditor may not be able to retain a payment made or collateral granted if the debtor files a bankruptcy petition within ninety days, the creditor may be deterred from grabbing the debtor's assets on the eve of bankruptcy. ${ }^{509}$ While this vision may be plausible in some contexts, most agree that deterrence is, at best, an incomplete explanation and justification. For example, many creditors no doubt strongly encourage a

508. 11 U.S.C. $\$ 547($ b)(5) (2000).

509. See, e.g., H.R. REP. NO. 95-595, at 177 (1977) (stating that voidable preference law might discourage creditors "from racing to the courthouse to dismember the debtor during his slide into bankruptcy"). 
payment sooner rather than later in the hopes that the ninety-day period will elapse before a bankruptcy petition is filed. ${ }^{510}$

The other justification is that voidable preference law promotes a policy of equality among creditors. "Second, and more important [than deterrence], the preference provisions facilitate the prime bankruptcy policy of equality of distribution among creditors of the debtor." ${ }^{511}$ By forcing the transferee to regurgitate the payment (or collateral) to the end that the debt becomes once again unpaid (or unsecured), voidable preference law steps in to set things as they were when it has failed as a deterrent. To the extent that equality is the principal, or a principal, goal of voidable preference law, of course, the deterrence function (when effective) directly serves the equality policy by causing the assets to remain in place.

In adopting the Bankruptcy Code in 1978, Congress appeared to favor the policy of equality over that of deterrence, as suggested by the language quoted above from the House Report. An additional indication was the rejection by Congress of the element of the transferee's knowledge or notice of insolvency, which featured in the avoidability of preferences under the Bankruptcy Act. ${ }^{512}$ The transferee's state of mind would be significant only if the goal is deterrence - one wholly ignorant of the debtor's financial distress would not be motivated to "grab" assets on the "eve of bankruptcy." ${ }^{513}$ Professor Tabb has argued, however, that one of the exceptions to voidability demonstrates that preference law is not primarily worried about equality. Because Section 547(c)(2) excepts from avoidance ordinary course payments of debts incurred in the ordinary course, leaving only "unusual" payments to be avoided, he believes that this exception "eviscerates equality." ${ }^{514}$ In effect, the ordinary course exception "resurrected the same core principal of culpability" that was found in the Bankruptcy Act's "reasonable cause to believe" test. ${ }^{515}$ Professor Tabb may overstate the case inasmuch as many payments made shortly before a bankruptcy filing will not find cover under the ordinary course exception. Moreover, transfers such as security interests and other liens will remain

510. For a brief critique of the deterrence rationale for voidable preference law, see Crucible, supra note 268, at 215-16 (critiquing the deterrence rationale).

511. H.R. REP. No. 95-595, at 177-78 (1977).

512. Bankruptcy Act, Pub. L. No. 696, $§ 60($ b), 52 Stat. 840 (1938) (repealed 1978) (voidability required proof that the transferee had "reasonable cause to believe the debtor was insolvent at the time of such transfer").

513. See H.R. REP. No. 95-595, at 178 (1977) ("[A] creditor's state of mind has nothing whatsoever to do with the policy of equality of distribution ....").

514. TABB, supra note $136, \S 6.18$, at 383 .

515. Id. 
vulnerable. ${ }^{516}$ But he surely is correct that the equality goal has not entirely squeezed out the culpability principle and the deterrence goal. ${ }^{517}$

Focusing on the exceptions in Section 547(c) also is useful in considering voidable preference law in the context of procedure theory. Recall that voidable preference law addresses transfers that are valid under nonbankruptcy law as between the transferor and transferee and, in general, as against third parties. These transfers are not necessarily tainted under nonbankruptcy law by wrongful intent or insufficient value as are transfers avoidable under fraudulent transfer law. Voidable preference law, however, can be reconciled with procedure theory under the same analysis applicable to pro rata sharing in a collective proceeding. ${ }^{518}$ To the extent that it promotes equality it furthers the goal of pro rata sharing, and, as noted above, to the extent that it effectively promotes deterrence, that also promotes equality and pro rata sharing. The Section 547(c) exceptions, however, recognize that preference law will not disrupt all transfers that are valid under nonbankruptcy law and that otherwise meet the elements of voidability under Section 547(b). Drawing on Professor Tabb's views of the impact of Section 547(c)(2), procedure theory can be rationalized best with the exceptions to avoidance by viewing them as establishing a set of nonculpability tests. When the excepted transfers are viewed as examples and proxies for circumstances in which any gun-jumping manipulation of the bankruptcy process would be unlikely, excepting these transfers from avoidance and respecting the transfers, valid under nonbankruptcy law, recognizes the appropriate domain for a bankruptcy-only voidability rule in the context of voidable preference law. ${ }^{519}$ Under this

516. 11 U.S.C. $\$ 547(c)(2)(A)(2000)$ (defining preferences to include transfers made "in payment of a debt") (emphasis added).

517. As Carlson has pointed out, "[t]he complete theory of voidable preferences has yet to be articulated, and even the most sophisticated accounts of it cannot help but fall into contradiction." Crucible, supra note 268, at 213. Carlson also argues that manipulating the timing of a transfer of a security interest for purposes of voidable preference law joins the strong-arm power in punishing secret liens. $I d$. at 218 . He further notes that this function also served the interests of the "nation-building" and nationalism interests by ensuring that secret, local liens would not prevail over national creditors who could not discover the liens. Id. at 217-18.

518. See supra Part IV.C (discussing pro rata sharing).

519. One might rationalize the exceptions as accommodations to circumstances in which the detrimental effects of avoidance, instrumental and otherwise, would outweigh the benefits of equality and pro rata sharing. For example, one could argue that the "ordinary course" exception in $\$ 547(\mathrm{c})(2)$ encourages repose and finality in commercial transactions. While that is a perfectly plausible analysis, procedure theory would view it as just another example of offensive social engineering in the Bankruptcy Code. Focusing on deterring and rectifying prebankruptcy manipulations that impede equality, however, focuses on a goal of bankruptcy law. 
nonculpability standard, then, equality would give way to legitimate prebankruptcy transfers that do not jeopardize the bankruptcy process. It follows that procedure theory would be served best by a broad and general exception for routine, ordinary transfers that would not be limited (as is Section $547(\mathrm{c})(2))$ to payments alone. ${ }^{520}$

\section{Fraudulent Transfers}

Another important avoiding power is the trustee's power to avoid fraudulent transfers. But fraudulent transfers are avoidable outside bankruptcy as well. An avoidable fraudulent transfer may involve a debtor's actual intent to defraud its creditors by attempting to put assets out of the creditors' reach. ${ }^{521}$ Alternatively, while "innocent," a transfer nonetheless may amount to constructive fraud because the debtor receives nothing in exchange for a transfer of assets or receives less than the value of the assets. ${ }^{52}$ In each case, were the transfers to stand, the transferred assets would be unavailable for the satisfaction of creditor claims and no assets - or assets of a lower value-would remain.

Under Bankruptcy Code Section 548, the trustee can avoid certain transfers made within one year before the date on which a bankruptcy petition is filed. ${ }^{523}$ Although Section 548 is a federal rule applicable only in bankruptcy, it embodies longstanding principles of nonbankruptcy fraudulent transfer law. ${ }^{524}$ For this reason, Section 548 generally may be squared with procedure theory under the consistency test. Like the strong-arm power, Section 548 also complements pro rata sharing. In effect, it puts the value of assets back in the

520. Once again, as a normative theory procedure theory can offer guidance such as that in the text but cannot provide specific instructions on detailed questions, such as whether the preference reachback periods (ninety days, in most cases, and up to one year, in the case of insider transferees) are optimal. See 11 U.S.C. $\$ 547(b)(4)$ (2000) (providing the prebankruptcy time periods for transfers made that trustee may avoid).

521. See, e.g., U.F.T.A. $\$ 4($ a)(1), 7A U.L.A. 301 (1999) (concerning the debtor's "intent to hinder, delay or defraud" any creditors).

522. See, e.g., U.F.T.A. $\$ \S 4(a)(2), 5(a), 7$ A U.L.A. 301-05 (1999) (providing that a transfer may be fraudulent "if the debtor made the transfer or incurred the obligation . . . without receiving a reasonably equivalent value in exchange").

523. 11 U.S.C. $\$ 548(a)(1)(2000)$.

524. Compare 11 U.S.C. $\$ 548(a)(1)(2000)$ (concerning actual fraud) and 11 U.S.C. $\S 548(\mathrm{a})(2)$ (2000) (concerning constructive fraud), with UNIFORM FRAUDULENT CONVEYANCE ACT $\$ \$ 7,7$ A U.L.A. 113 (1999) (concerning actual fraud), and 4-6, 7A U.L.A. 67, 105, 110 (1999) (concerning constructive fraud), and U.F.T.A. $\$ \$ 4(\mathrm{a})(1), 7$ A U.L.A. 301 (1999) (concerning actual fraud), and 4(a)(2), 5(a), 7A U.L.A. 301, 330 (1999) (concerning constructive fraud). 
debtor's estate that were transferred wrongfully or to the extent that insufficient value was received by the debtor in exchange for the transfer. It mimics the rights of creditors to avoid fraudulent transfers under nonbankruptcy law and preserves the benefits for the debtor's creditors generally, following the collective judicial lien paradigm. ${ }^{525}$

In general, these observations concerning Section 548 apply as well to the avoidance of fraudulent transfers under Bankruptcy Code Section 544(b)(1), which empowers the trustee to avoid a transfer of property by the debtor which "is voidable under applicable law by a creditor holding an unsecured claim." 526 Unlike Section 544(a)(1), under which the trustee receives the powers of a hypothetical judgment lien creditor, Section 544(b)(1) permits the trustee to assert the avoidance rights only of an actual creditor of the debtor. ${ }^{527}$ Like Section 544(a)(1), however, under Section 544(b)(1) the trustee must find the substance of its avoidance power under "applicable law"-nonbankruptcy law. ${ }^{528}$

From the foregoing it appears that one can reconcile avoidance of fraudulent transfers with procedure theory. Not only are the application of Bankruptcy Code Sections 544(b) and 548 generally consistent with nonbankruptcy law, but they fit the model of trustee as judicial lienholder for the benefit of all creditors. They thereby complement the goal of pro rata sharing and, as with the strong-arm power, can be reconciled with procedure theory on the same basis. Nonetheless, in some respects the application of these sections does not comport with procedure theory. Accordingly, procedure theory calls for modifications.

525. See U.F.T.A. \$ 4, 7A U.L.A. 301-36 (1999) (concerning transfers avoidable by creditors whose claims arose before or after the transfer); U.F.T.A. $\$ 5$, 7A U.L.A. 301-36 (1999) (concerning transfers avoidable by creditors whose claims arose before the transfer). Carlson conceptualizes fraudulent transfer avoidance as a part of the strong-arm organizing principle's model of the trustee holding a judicial lien for the benefit of all creditors. See Organizing Principle, supra note 79, at 563-73 (discussing fraudulent conveyances).

526. 11 U.S.C. $\$ 544(b)(1)(2000)$. Although Section 544(b)(1) applies to any transfer that is voidable under applicable (usually, state) law, its principal applicability is in the context of fraudulent transfer law. Another nonbankruptcy law permitting avoidance by an unsecured creditor relates to a "sale or return" of goods. See U.C.C. \$ 2-326(2) (1999) (defining "sale on approval" and "sale on return"); see also TABB, supra note 136, §6.5, at 344 (discussing other state laws available to the trustee in bankruptcy).

527. TABB, supra note $136, \S 6.5$, at 343 .

528. Assuming the trustee can identify an actual creditor that could set aside a transaction under applicable nonbankruptcy law, it may allow the trustee to avoid transfers that could not be avoided under Section 548. State fraudulent transfer statutes of limitation generally are longer than the one-year reachback of Section 548. See id. $\S 6.5$, at 345-46 (discussing the reachback time period of fraudulent transfer laws) 
As noted above, both the Section 544(a)(1) strong-arm power and the derivative (from nonbankruptcy law) power of the trustee under Section 544(b)(1) to avoid transfers that an actual creditor could avoid each depends on substantive nonbankruptcy priority rules. These sections adapt those rules to bankruptcy's collective proceeding. Section 548, however, is quite different in concept. Although its substantive provisions are quite similar to widely accepted nonbankruptcy systems of fraudulent transfer law, Section 548 is, nonetheless, a freestanding, bankruptcy-only rule. Its provisions can apply to override some transfers that would be unassailable under nonbankruptcy law. ${ }^{529}$ That is to say, in some cases nonbankruptcy law commands that a prebankruptcy transfer must stand, and Section 548 commands that it must fall. ${ }^{530}$ To that extent, Section 548 offends procedure theory. ${ }^{531}$

Granted, it is entirely possible that Section 548 provides a superior framework for fraudulent transfer law. One also can imagine collateral benefits from a modern, well-drafted, nationally applicable, uniform standard. By virtue of Section 544(b) and varying fraudulent transfer regimes under nonbankruptcy law, Section 548, however, does not impose uniformity; it creates a separate stand-alone regime that deviates from nonbankruptcy law. Moreover, were Congress actually to seek a uniform and well-designed fraudulent transfer regime, it could enact a single federal fraudulent transfer statute that would apply generally, not solely in bankruptcy. ${ }^{532}$

For similar reasons, the operation of Section 544(b) also offends procedure theory. To the extent that a transfer is avoidable only in part under

529. For example, the applicable state law fraudulent transfer statute might be narrower in scope than Section 548 .

530. Section 548 is agnostic as to whether a transfer is avoidable under applicable law by a creditor whose claim arose after the transfer (a "future creditor") or would be avoidable only by a creditor whose claim existed at the time the transfer was made (an "existing creditor"). Consequently, the operation of Section 548 can serve to transfer wealth capturable by existing creditors to future creditors. As explained below, Section 544(b), as applied by the courts, can achieve the same result.

531. Perhaps the best defense of Section 548 against procedure theory is that it complements pro rata sharing and the bankruptcy process. When a debtor hides assets or gives them away, they no longer would be available for the satisfaction of creditors' claims absent a means to recover them for the benefit of all creditors. When this occurs temporally sufficiently close to the time of a bankruptcy filing, it disrupts bankruptcy's goal of an orderly and fair process to vindicate the rights of rightsholders. This argument was developed in the discussion of voidable preferences. See supra Part IV.E.2 (discussing preferences).

532. This theory assumes that Congress has the power to enact generally applicable fraudulent transfer legislation notwithstanding recent Supreme Court decisions narrowing the scope of its power under the Commerce Clause. See, e.g., United States v. Lopez, 514 U.S. 549, 567-68 (1995) (holding that Congress does not have the authority under the Commerce Clause to ban weapons from school zones). 
nonbankruptcy law, one would think that the derivative power of the trustee under Section 544(b) would be avoidance only to the extent avoidable under nonbankruptcy law-limited to the aggregate amount of the claims held by the actual creditors in whose shoes the trustee stands. Similarly, one would expect that if the transfer were avoidable under nonbankruptcy law only by certain creditors and not by others, that the value captured by the trustee under Section 544(b) would be distributed only to the actual creditors who possessed the nonbankruptcy avoidance rights. But the famous case of Moore v. Bay ${ }^{533}$ teaches otherwise.

As Moore is generally understood and applied, the trustee in bankruptcy can avoid an entire transfer; the avoidance is not limited to the extent to which the actual creditor or creditors in whose shoes the trustee stands could have avoided the transfer. ${ }^{534}$ For example, if property worth $\$ 100$ is transferred and the creditors eligible to avoid the transfer under nonbankruptcy are owed only $\$ 50$ in the aggregate, outside bankruptcy the transfer could be avoided only to the extent of $\$ 50 .{ }^{535}$ But under Section 544(b)(1), interpreted according to Moore, the trustee could avoid the entire $\$ 100$ transfer - a result that punishes the transferee and transfers the additional $\$ 50$ of value from the transferee to the debtor's creditors. ${ }^{536}$ Similarly, outside of bankruptcy only the creditors in the class entitled to avoid the transfer could share in the value of the transferred asset. Under the Moore analysis of Section 544(b)(1), however, all of the unsecured creditors will share the $\$ 100$ in reclaimed value, thereby transferring wealth from the entitled-to-avoid class to the other unsecured creditors. ${ }^{537}$ Clearly, the application of Section 544(b)(1) under Moore contravenes procedure theory.

533. Moore v. Bay, 284 U.S. 4, 5 (1931).

534. See TABB, supra note $136, \S 6.6$, at 347 (discussing Moore).

535. See, e.g., U.F.T.A. \$7(a), 7A U.L.A. 339 (1999) (stating that "creditor . . may obtain ... avoidance of the transfer ... to the extent necessary to satisfy the creditor's claim") (emphasis added).

536. Moore addressed the predecessor to $\S 544(\mathrm{~b})(1)$, Bankruptcy Act $\S 67(\mathrm{~d})$. As Professor Tabb has declared: "[T]he trustee is given a license by $\S 544(\mathrm{~b})[(1)]$ to rob Peter (X) [the transferee in his example] to pay Paul (general creditors)." TABB, supra note 136, $\S 6.6$, at 348 .

537. See TABB, supra note $136, \S 6.6$, at $347-48$ (providing an example of the application of the result in Moore). Arguably, one might rationalize this aspect of the Moore doctrine with procedure theory as an example of nonbankruptcy entitlements that must give way to the collective norm in bankruptcy and as an analogy to pro rata sharing. I would be unconvinced. At best, this feature of the doctrine may be only slightly less offensive than permitting recovery of the entire transfer from the transferee. 


\section{F. Assumption and Rejection of Executory Contracts and Leases}

Whether considered against the backdrop of procedure theory, as a doctrinal matter alone, or from any other perspective, the treatment of executory contracts and leases under the intricate provisions of Bankruptcy Code Section 365 is one of the most bewildering artifacts of bankruptcy law. Conflicting case law and a legacy of wrongheaded, poorly reasoned judicial decisions have compounded the confusion. An article of broad scope such as this one can only hope to address the most basic features of this body of law. The following discussion considers the extent to which these basic features of Section 365 conform to the procedure theory of bankruptcy law.

For present purposes, it is sufficient to adopt the standard conception of an "executory contract" developed by Professor Countryman; a contract as to which both the debtor's and the other party's obligations are "so far unperformed that the failure of either to complete performance would constitute a material breach excusing the performance of the other." ${ }^{538}$ A typical example is a contract for the sale of goods-say, apples - under which the seller has not yet delivered the goods, and the buyer has not yet paid. The debtor in a bankruptcy case could, of course, be either the seller or the buyer. For now, assume that the debtor is the buyer. If the contract is a burdensome one, say, because the contract price of the apples is $\$ 10$ per bushel but the market price is $\$ 8$, the debtor would prefer to be relieved of the contract. Then it could buy the apples in the market at a lower price. It is true that if the debtor is in breach of the contract it must answer in damages, which outside bankruptcy likely would consume the benefits of the opportunity to buy at a lower market price following the buyer's breach. ${ }^{539}$ But, assuming the debtor is insolvent, in bankruptcy the debtor would only be required to satisfy the seller's pro rata share of the damage claim. In this example, the debtor's trustee likely would seek to "reject" the contract. Now assume that the contract and market prices are reversed - the contract price is $\$ 8$, and the market price is $\$ 10$. Under these circumstances, the trustee likely will wish to "assume" the contract. By doing so, it can buy at the below-market contract price of $\$ 8$, thus preserving for the estate the value of the favorable contract.

538. Vern Countryman, Executory Contracts in Bankruptcy: Part I, 57 MINN. L. REv. 439, 460 (1973).

539. See U.C.C. \$2-708(1) (1999) ("[M] easure of damages for non-acceptance or repudiation by the buyer is the difference between the market price at the time and place for tender and the unpaid contract price...."). 
Under Section 365(a), subject to court approval, the trustee "may assume or reject any executory contract or unexpired lease of the debtor. ${ }^{540}$ Following assumption, the trustee also could seek to assign the contract to a third party. ${ }^{541}$ Or, at least for some period of time, the trustee might do nothing. ${ }^{542}$

\section{Rejection}

If the trustee rejects the contract, as in the first variation of the example, the rejection "constitutes a breach" that is given effect as if it occurred "immediately before the date of the filing of the petition." prebankruptcy breach, then, entitles the other party to an "allowed" claim, thereby entitling it to a pro rata distribution along with the other unsecured creditors. $^{544}$ This structure fits well with procedure theory. As under nonbankruptcy law, a party to a contract may repudiate it, and the resulting breach will trigger the other party's remedies-damages, in the example. If the other party in our example, the seller, was entitled to force the trustee to comply with the contract following bankruptcy, by taking and paying for the apples at the $\$ 10$ above-market contract price, then the seller would be fully satisfied because it would receive the entire benefit of its bargain to the detriment of the other creditors. The statutory structure for rejection, then, ensures that a party to an executory contract will not receive a windfall merely because the debtor was not in default when the bankruptcy petition was filed.

But what treatment does Section 365 afford equitable remedies? These might include a right to an injunction to enforce a debtor's covenant not to compete in connection with a rejected franchise agreement or a right of a buyer to specific performance of a contract to buy unique goods from the debtor under a rejected contract for sale. In short, nothing of general applicability in Section 365 appears to provide differing treatment based on whether the other party to an executory contract is entitled to equitable relief or solely money damages. Instead, the proper question is whether the rejection gives rise to a

540. 11 U.S.C. $\$ 365$ (a) (2000). For present purposes, it is sufficient to note that for the most part leases are special types of executory contracts.

541. See 11 U.S.C. $\$ 365(f)$ (2000) (providing the trustee may assign an executory contract or lease notwithstanding a provision to the contrary); see also infra notes 566-72 and accompanying text (discussing assignment).

542. See infra notes 573-74 and accompanying text (discussing time limitations of court orders).

543. 11 U.S.C. $\$ 365(\mathrm{~g})(1)(2000)$.

544. 11 U.S.C. $\$ 502(\mathrm{~g})(2000)$. 
"claim." ${ }^{545}$ If the equitable remedy gives rise to a right to payment, then it is a "claim." ${ }^{546}$ As among the holders of unsecured claims, bankruptcy law's equality policy dictates that the holder of a claim arising out of an equitable remedy, as with the holder of any other unsecured claim, should receive a pro rata distribution and should not have the equitable remedy actually imposed. ${ }^{547}$ Moreover, because the equitable remedy gives rise to a claim, it can be discharged. ${ }^{548}$ This treatment of claims arising out of equitable remedies does not offend procedure theory. ${ }^{549}$ It merely applies the policy of equality as among money claimants as reflected by pro rata sharing. ${ }^{550}$ The chief point for present purposes is that determining whether a breach arising out of a rejection of an executory contract creates a "claim" depends on an analysis of nonbankruptcy law. ${ }^{551}$

Rejection of an executory contract or lease gives rise to a "breach," but procedure theory dictates that rejection should not deprive the nondebtor other party of a property interest that it may have received pursuant to the contract or lease. Procedure theory views setting aside prebankruptcy transfers of property as the domain of the trustee's avoiding powers. ${ }^{552}$ For example, a lessee of personal property acquires a property interest in the leased goods. ${ }^{553}$ Rejection of the lease by the debtor-lessor would constitute a breach but, under procedure theory, should not deprive the lessee of its property rights, including possession and use of the goods, so long as it complies with the terms of the lease. ${ }^{554}$ Nonetheless, some courts have held, contrary to procedure theory's approach,

545. 11 U.S.C. $\$ 101(5)(B)(2000)$ (defining a "claim" that arises out of an equitable remedy).

546. TABB, supra note $136, \S 8.8$, at 595 .

547. Id. (discussing circumstances when an equitable remedy is a claim).

548. See, e.g., 11 U.S.C. $\$ 727$ (b) (2000) (providing for discharge of prebankruptcy debts and claims); see also infra Part IV.G (discussing discharge and procedure theory).

549. See supra notes 420-31 and accompanying text (discussing equitable remedies as claims and as nonclaim legal entitlements).

550. See supra Part IV.E (discussing the trustee's avoiding powers).

551. See \$11 U.S.C. 502(g) (2000) ("A claim arising from the rejection... shall be allowed ....") (emphasis added). In some cases, however, the Bankruptcy Code's treatment of claims does not comport with procedure theory. See supra notes $439-45$ and accompanying text (discussing disallowance of claims for unmatured interest and caps on certain damage claims).

552. See supra Part IV.E (discussing the trustee's avoiding powers).

553. See U.C.C. § 2A-103(1)(m) (1999) (defining "leasehold interest" as lessee's or lessor's interest under a leasing contract); U.C.C. \$1-201(b)(29) (1999) (including "taking by ... lease" as a type of "purchase" that "creat[es] an interest in property").

554. See TABB, supra note $136, \S 8.8$, at 592-95 (discussing the example of a lease). 
that rejection effects a termination or rescission and that the other party to a contract or lease is entitled only to damages arising out of a breach. ${ }^{555}$

\section{Assumption}

A debtor's assumption of an executory contract or lease binds the estate to perform the contract in full and entitles the estate to the benefits of the contract. ${ }^{556}$ An assumption under Section 365 generally respects the nonbankruptcy entitlements of the nondebtor party. Consequently, it is the quintessential embodiment of procedure theory's goals. And inasmuch as the benefits will inure to the debtor's rightsholders generally, it also is consistent with the equality policy of pro rata sharing. Nonetheless, the assumption scheme of Section 365 overrides some aspects of a nondebtor party's nonbankruptcy legal entitlements. The following discussion tests these features against procedure theory.

If no default exists under an executory contract, then the nondebtor party has no basis to complain that an assumption interferes with its nonbankruptcy entitlements. But if a default exists, the nondebtor party may have reason to object. Section 365(b)(1) requires the trustee, as a condition precedent to an assumption, to cure all defaults and compensate the nondebtor party for actual pecuniary losses arising out of the default. ${ }^{57}$ Alternatively, the trustee may "provide adequate assurance" of a prompt cure and compensation for losses. In addition, the trustee must provide "adequate assurance of future performance." ${ }^{558}$ On one view, these protections benefit the nondebtor party, who might not wish to be held to the contract except with a reasonable

555. Id. For this reason Professor Tabb harshly criticizes Lubrizol Enter., Inc. v. Richmond Metal Finishers, Inc., 756 F.2d 1043 (4th Cir. 1985), cert. denied, 475 U.S. 1057 (1986), and its ilk. TABB, supra note $136, \S 8.8$, at $592-95$ (discussing the effects of termination or recession). He also points out that special provisions in Section 365 which protect the property rights of nondebtor parties to certain types of contracts and leases could erroneously be read to create a negative inference that where such protections are not explicit in the statute, a party to a contract or lease would lose its property rights upon rejection. Id. $\$ 8.9$, at 596 .

See 11 U.S.C. $\$ 365(\mathrm{~h})(2000)$ (regarding real property leases and timeshare contracts when debtor is lessor or seller); 11 U.S.C. $\$ 365(\mathrm{j})$ (2000) (regarding real property and timeshare sale contracts when debtor is vendor); 11 U.S.C. $\$ 365(\mathrm{n})(2000)$ (regarding license of intellectual property when debtor is licensor). In support of the view that rejection does eliminate any property interest acquired by the nondebtor other party to a contract or lease, see generally Laura B. Bartell, Revisiting Rejection: Secured Party Interests in Leases and Executory Contracts, 103 Dick. L. REV. 497, 504, 514, 526-43 (1999).

556. See TABB, supra note $136, \S 8.13$, at $609-11$ (discussing the effects of assumption).

557. 11 U.S.C. $\$ 365(\mathrm{~b})(1)(\mathrm{A})-(\mathrm{B})(2000)$

558. 11 U.S.C. $\$ 365(b)(1)(C)(2000)$. 
expectation that the future will not hold additional defaults or nonperformance. On the other hand, what is implicit in this structure is the nondebtor party's inability to exercise any otherwise applicable right to terminate or cancel the contract pursuant to its terms, applicable law, or both. ${ }^{559}$ The goal of assumption nonetheless is to make the nondebtor party whole and to put it in as good a position as if no default ever occurred. The mandatory cure rights for the trustee represent a rational and reasonable procedure for ensuring respect of the nondebtor party's nonbankruptcy entitlements, the essential goal of procedure theory, while permitting the trustee to preserve a valuable asset. ${ }^{560}$ Of course, had the nondebtor party exercised a right to terminate or cancel before the filing of the bankruptcy petition, there would be no contract left to be assumed. ${ }^{561}$

Ironically, procedure theory does find fault with the scheme for assumption in Section 365 when the contract of lease is not in default. In that situation, the trustee is entitled to assume without providing adequate assurance of future performance even if those assurances would be required under nonbankruptcy law. ${ }^{562}$

There is another important exception to the requirement that the trustee cure defaults (or provide reasonable assurance of a prompt cure) as a condition of assumption. The trustee need not cure defaults arising from a breach relating to the debtor's insolvency or financial condition, the commencement of a bankruptcy case, or the prepetition appointment of or taking possession by a trustee or custodian. These so called "ipso facto" or "bankruptcy" defaults generally permit the nondebtor party to terminate the contract or lease or provide for automatic termination. ${ }^{563}$ Before this exception was built into

559. The Bankruptcy Code does not speak explicitly to such a postpetition termination, but most courts have held it unavailable. See generally Douglas W. Bordewiek, The Postpetition, Pre-Rejection, Pre-Assumption Status of an Executory Contract, 59 AM. BANKR. L.J. 197, 20213 (1985). Plank argues that prohibiting a termination on a basis other than an ipso facto provision is unconstitutional. Federalism, supra note 136, at 1122.

560. The inherent delay involved in the rejection-assumption process is addressed below. See infra notes 573-74 and accompanying text (arguing that a reasonable delay and the "limbo" period before rejection or assumption are in general necessary procedural aspects of the bankruptcy system, analogous to the automatic stay).

561. See TABB, supra note $136, \S 8.14$, at 611 (stating that a contract must exist at the time of bankruptcy).

562. 11 U.S.C. $\$ 365(\mathrm{~b})(1)(\mathrm{C})(2000)$ (providing requirement of adequate assurance of future performance required only if there has been a default). Plank argues that this defect raises a constitutional issue. Federalism, supra note 136, at 1122-23.

563. 11 U.S.C. $\$ 365(\mathrm{~b})(2)(2000)$. The trustee also is not required to cure a default based on a "penalty rate or provision relating to a default arising from any failure by the debtor to perform nonmonetary obligations." 11 U.S.C. $\$ 365(b)(2)(D)(2000)$. 
Section 365, when the Bankruptcy Code was enacted in 1978, courts generally enforced these defaults under the Bankruptcy Act, resulting in the unavailability for assumption of many otherwise valuable contracts and leases.

By reading these ipso facto provisions out of the parties' bargain, this exception to the cure-of-default requirement clearly tramples on the nonbankruptcy entitlements of the nondebtor party. Can it be reconciled with procedure theory? Perhaps it can, based on reasoning similar to that applied to the cure-of-default requirement. Because bankruptcy is a procedural system designed to maximize the recoveries and benefits for rightsholders, preserving valuable assets such as executory contracts and leases furthers that goal. Inasmuch as ipso facto defaults and terminations, if effective in bankruptcy, would be common, if not ubiquitous, overriding these clauses provides substantial assistance in preserving this value. While ordinarily putting one person's (the nondebtor party's, here) entitlements at risk to benefit others (unsecured creditors and other rightsholders, here) offends procedure theory, in the assumption context it may not. In that context, the protective provisions"adequate assurance"-are such that the nondebtor party can expect to receive all of the benefits that it would have received outside bankruptcy and absent any default. ${ }^{564}$ This rationalization is roughly analogous to procedure theory's consistency with "adequate protection" in the context of a debtor's use of property. ${ }^{565}$ In the end, this conclusion is somewhat tentative. If not offended, procedure theory is at least annoyed that Section 365 overrides ipso facto provisions to which parties have agreed.

564. The stated conclusion relies heavily on the "adequate assurance" of cure, compensation, and future performance required by Section $365(\mathrm{~b})(1) .11$ U.S.C. $\$ 365(\mathrm{~b})(1)$ (2000). As already noted, if no default has occurred, the absence of a duty to provide adequate assurance of future performance otherwise required under nonbankruptcy law does offend procedure theory. If, in any case, cure, compensation, or future performance does not in fact occur then the assurance provided necessarily was not adequate. One would hope that any judges who habitually determine to be adequate what turns out to be inadequate would be sanctioned or removed.

565. See infra Part IV.J (discussing relief from the automatic stay and adequate protection). Plank believes that giving effect to ipso facto defaults for the benefit of the other party would violate the Non-Interference Principle and that preventing the other party from relying on a bankruptcy filing or the like under an ipso facto clause does not violate the Non-Expropriation Principle. Federalism, supra note 136, at 1123 n.215, 1126-32. Accordingly, he believes that Section 365 is constitutionally acceptable in this respect. $I d$. Admirably, out of concern for the interests of nondebtor parties, $\$ 365$ does not permit the assumption of certain contracts and leases. These include personal service contracts, such as an opera singer or artist, and other contracts that are nondelegable under nonbankruptcy law, absent consent from the nondebtor party, and contracts to make a loan or otherwise to extend financing. 11 U.S.C. $\$ 365(\mathrm{c})(1)-(2)$ (2000). 


\section{Assignment}

Section 365 appropriately recognizes that an executory contract or lease may have a greater value if assigned to a third party than would be the case if it was retained by the debtor. For example, a trustee, including a Chapter 11 debtor in possession, may lack sufficient financing and other resources necessary to perform the contract or lease itself, even though it would be profitable or otherwise valuable to another party. Accordingly, Section 365 facilitates the assignment of a contract or lease by the trustee in order to preserve its value. But Section 365 also recognizes the interests of the nondebtor party. It requires, as a condition of assignment, that the trustee assume the contract or lease, thus invoking the protective provisions such as curing defaults and compensation for the nondebtor party's losses, ${ }^{566}$ as well as providing adequate assurance of the assignee's future performance. ${ }^{567}$ Notwithstanding its significant appreciation of the risks that might be imposed on a nondebtor party by an assignment, Section 365 nonetheless interferes with a nondebtor party's nonbankruptcy entitlements in two material respects. These infringements must confront procedure theory's baseline insistence that substantive nonbankruptcy entitlements be respected.

First, Section 365 overrides and nullifies contractual restrictions on assignment, such as provisions that prohibit assignment or that would terminate or modify the contract or lease upon assignment, even though those restrictions may be effective under nonbankruptcy law. ${ }^{568}$ Second, it imposes a novation on the nondebtor party following an assignment- the trustee and the estate are relieved from liability, and the obligations of the assignee are substituted for that liability. ${ }^{569}$ Consequently, the nondebtor party's future interests depend on the adequate assurance of the assignee's future performance, mentioned above. For the same reasons and on the same analysis presented above, ${ }^{570}$ these adequate assurance and other nondebtor party protections arguably could reconcile procedure theory with a novation that substitutes the assignee's performance for that of the trustee following assignment. But procedure theory probably should condemn the nullification of contractual restrictions on assignment which force a nondebtor party into an ongoing relationship with a

566. See supra notes 557-61 and accompanying text (discussing assumptions of executory contracts).

567. 11 U.S.C. $\$ 365(\mathrm{f})(2)(2000)$.

568. 11 U.S.C. $\$ 365(\mathrm{f})(1)-(3)(2000)$.

569. 11 U.S.C. $\$ 365(\mathrm{k})(2000)$.

570. See supra notes 563-65 and accompanying text (discussing assumption notwithstanding an ipso facto bankruptcy default provision). 
stranger. There may be important reasons why the nondebtor party may wish to pick and choose its business relationships notwithstanding assurances of performance. ${ }^{571}$ Indeed, Plank argues that overriding the otherwise effective restriction on assignment is unconstitutional. ${ }^{572}$

\section{Timing and Delay}

In addition to opting for rejection, assumption, or assignment and assumption of an executory contract or lease, the trustee has a fourth optiontake no action. The timing of the trustee's decision often is of extreme importance and concern to a nondebtor party. Several specific rules in Section $365(\mathrm{~d})$ address the timing issue. The baseline rule in a Chapter 11 case permits assumption or rejection "at any time before confirmation of a plan," but it authorizes the court to order the trustee to decide "within a specified period" if requested by a nondebtor party to a contract or lease. ${ }^{573}$

One could hardly imagine a more procedural aspect of bankruptcy law than the timing issue. Obviously, the trustee must have an opportunity to investigate, analyze, and assess the potential value or burden of the debtor's contracts and leases, and procedure theory should be accommodating. However, a general reconciliation of procedure theory with the central features of the statutory scheme for rejection, assumption, and assignment of executory contracts and leases depends primarily on its protection of the nonbankruptcy entitlements of the nondebtor party. Accordingly, what procedure theory can accept in concept, a reasonable delay, could be rendered unacceptable by the exercise of judicial discretion that fails to afford reasonable protection for these

571. I use the word "probably" advisedly in the preceding sentence. It is possible that a study of the sort of legal restrictions - as opposed to contractual restrictions-on assignment which, under Section 365(c), are not overridden would reveal an adequate source of protection for the interests of nondebtor parties. When the obligation owed to a person such as the nondebtor party amounts only to an obligation to pay money, the trend in nonbankruptcy law is to render restrictions on assignment (both contractual and legal) ineffective. See U.C.C. 9406(d) (1999) (providing that contractual restrictions on certain assignments of accounts, chattel paper, and payment intangibles are ineffective); U.C.C. 9-406(f) (1999) (providing that legal restrictions on assignments of accounts, chattel paper, and payment intangibles are ineffective). Although Section 365(f) might be reconciled with procedure theory through nuanced statutory modifications that distinguish various types of contracts and leases, procedure theory is served best by deference to nonbankruptcy law.

572. See Federalism, supra note 136, at 1122 (discussing the exercise of state law rights).

573. 11 U.S.C. $\$ 365(d)(2)(2000)$. This provision also applies in Chapters 9, 12, and 13. 
entitlements. It follows that procedure theory would favor more precise, clearly drawn time limitations with less judicial discretion to grant extensions. ${ }^{574}$

\section{G. The Individual Debtor's Discharge and the "Fresh-Start" Principle}

Procedure theory calls on bankruptcy law to provide a system that enforces nonbankruptcy legal entitlements and enhances the recoveries of a debtor's rightsholders. Yet a central feature - if not the central feature-of an individual's Chapter 7 bankruptcy case is the debtor's entitlement to a discharge of prebankruptcy claims. ${ }^{575}$ Following discharge, creditors are enjoined from seeking to recover on their discharged claims. ${ }^{576}$ At first blush an individual's right to a discharge seems to conflict directly with procedure theory. Unsatisfied claims essentially are abolished. ${ }^{577}$ This section addresses the relationship between procedure theory and the individual's bankruptcy discharge.

The bankruptcy discharge of claims against an insolvent debtor is a venerable concept. ${ }^{578}$ The first bankruptcy law providing for a discharge under English law was contained in the Statute of 4 Anne. ${ }^{579}$ Bankrupts who were

574. See, e.g., 11 U.S.C. $\$ 365(d)(1)$ (2000) (providing a contract or lease is deemed rejected in a Chapter 7 case if the trustee fails to assume or reject it within sixty days after the date of the bankruptcy filing, unless extended by the court "for cause"). An alternative view is that the timing question is purely procedural and therefore strictly consistent with procedure theory's acceptance of bankruptcy law as a procedural system for vindicating nonbankruptcy entitlements. Under this view, unreasonable delays do not contravene procedure theory; they simply amount to ineffective and inefficient procedure.

575. See 11 U.S.C. $\$ 727$ (b) (2000) (providing for a debtor's discharge from all prebankruptcy debts and certain other claims); see also 11 U.S.C. $\$ 727$ (a) (2000) (setting out exceptions under which no discharge will be given); 11 U.S.C. $\$$ 523(a) (2000) (specifying exceptions to the discharge of specific debts).

576. See 11 U.S.C. $\$ 524$ (a) (2000) (voiding judgments on discharged debts, enjoining enforcement of discharged debts, and enjoining enforcement against certain property of the debtor).

577. The statement in the text accurately describes the result in most cases. As a conceptual matter, however, discharged claims are not extinguished. While the discharge voids prebankruptcy judgments, it operates only as an injunction against enforcement of discharged claims. 11 U.S.C. $\$ 524$ (a) (2000). Discharged claims may be reaffirmed by a debtor, subject to protective restrictions, and a debtor may voluntarily pay a discharged claim. 11 U.S.C. $\S 524(c)-(d)$, (f) (2000) (governing reaffirmations and voluntary repayment).

578. For an excellent historical overview of the development of the bankruptcy discharge under English and United States law, see generally Discharge, supra note 254.

579. 4 Ann. c. 17 (1705). John McCoid points to earlier beginnings of the discharge in English law. See John C. McCoid, II, Discharge: The Most Important Development in Bankruptcy History, 70 AM. BANKR. L.J. 163, 177-78 (1996) (discussing the role of the Chancery in the early seventeenth century and an ordinance issued in 1654 (citing C.S. FIRTH \& 
honest and cooperative were entitled to a discharge of prebankruptcy debts, however, only if a majority of the bankrupt's "commissioners" certified that the bankrupt had acted in conformity to the act. ${ }^{580}$ While there is some disagreement as to the underlying motivations for Parliament's enactment of the Statute of 4 Anne, the most compelling view is that its overarching goal was to enhance the recoveries of creditors (perhaps supplemented by some human compassion for distressed debtors). ${ }^{581}$ As Charles Tabb explained:

The discharge was the "carrot" offered to induce debtors to cooperate in disclosing and turning over their estates; the death penalty was the "stick."

Certainly, the primary purpose of the act was to facilitate creditors' recoveries; the title of and preamble to the statute make that abundantly clear. One scholar states that the bill was introduced in direct response to the notorious frauds of Thomas Pitkyn in 1704. The prerequisite to the debtor receiving a discharge--"conforming" to the act-shows the fundamentally creditor-oriented basis of the law, since the required conforming activities were designed to enlarge and ease the creditors' recoveries. Furthermore, the very rapid retreat taken by Parliament, which soon required creditor consent to the discharge, indicates that the interests of the creditor were paramount. Finally, the predominance of the creditors' interests is shown by the limitation to traders, and the reservation to creditors of the right to institute bankruptcy proceedings. ${ }^{582}$

Offering a discharge as a tool for inducing debtor cooperation also was a justification advanced for the Bankruptcy Act of 1800 in the United States. ${ }^{583}$ And this concept continues to play a role in the availability of a discharge under current law. ${ }^{584}$

R.S. RAIT, II ACTS AND ORdINANCES OF THE INTERREGNUM, 1642-60, at 240 (4 Sept. 1649))).

580. Discharge, supra note 254, at 333-34.

581. See id. at 337 ("The primary purpose of the act was to facilitate creditors' recoveries.").

582. Id. at 336-37 (footnotes omitted).

583. Charles Jordan Tabb, The Scope of the Fresh Start in Bankruptcy: Collateral Conversions and the Dischargeability Debate, 59 GEO. WASH. L. REV. 56, 90-94 (1990) [hereinafter Fresh Start] (discussing this "debtor cooperation theory" of dischargeability); Margaret Howard, A Theory of Discharge in Consumer Bankruptcy, 48 OHIO ST. L.J. 1047, 1049-50 (1987) (identifying one "major function" of bankruptcy in the United States as a collection mechanism).

584. In noting that "[t]he debtor cooperation theory continues to thrive under current ... bankruptcy law," Tabb points out that most of the grounds for a complete denial of a discharge under current law are based on a debtor's noncooperation. Fresh Start, supra note 583, at 92 \& n.267. See 11 U.S.C. $\$ 727$ (a) (2000) (providing exceptions to discharge under Chapter 7). But Tabb also explains that provision for exceptions to the discharge do not fit well with the debtor 
The debtor cooperation paradigm meshes well with procedure theory. It illustrates that a debtor's right to a discharge in bankruptcy, while on one level serving to disadvantage the debtor's creditors, also could provide a net gain for the creditors. Perhaps, as an empirical matter, the discharge of individuals in bankruptcy has the effect of increasing recoveries of creditors, although that is far from clear. ${ }^{585}$ While it may continue to be recognized as a material justification for discharge, the debtor cooperation model does not provide a complete explanation of discharge (and exceptions to discharge) or a complete normative theory of discharge under past or current law.

In the years before and after enactment of the Statute of 4 Anne, considerable concerns were expressed for the plight of the insolvent debtor. ${ }^{586}$ The same can be said of the period that preceded the enactment of the

cooperation theory; these exceptions provide disincentives to debtor cooperation. Fresh Start, supra note 583 , at $92-94$.

585. An empirical showing to this effect would bring procedure theory into harmony with the discharge. But support by the consumer credit industry for bankruptcy reform suggests that some in the industry hold contrary beliefs. These reforms would screen out from eligibility for a Chapter 7 discharge consumer debtors who are thought to be able to pay a portion of their debts out of future income (so-called "means-testing"). See, e.g., Bankruptcy Abuse Prevention and Consumer Protection Act of 2003, H.R. 975, 108th Cong. (2003) (Engrossed as Passed by House) (providing a needs-based bankruptcy scheme). For critiques of these proposed reforms, see Jean Braucher, Means Testing Consumer Bankruptcy: The Problem of Means, 7 FordHAM J. CORP. \& FIN. L. 407, 454-55 (2002) ("If better means testing is wanted, attention needs to be paid to the means of achieving it, so that the worst off and most in need of a fresh start are not priced out of the consumer bankruptcy system."); Death, supra note 368, at 12-45 (critiquing the "means testing" approach); Marianne B. Culhane \& Michaela M. White, Taking the New Consumer Bankruptcy Model for a Test Drive: Means-Testing Real Chapter 7 Debtors, 7 AM. BANKR. INST. L. REV. 27, 61 (1998) ("[M]eans-testing as enshrined in H.R. 3150 will not go the distance.").

586. See Discharge, supra note 254, at 338-39 (discussing the English statutes' concern for the debtor) (footnotes omitted). The text states:

It would be a mistake, however, to ascribe to Parliament no concern for the debtor's interests. The century preceding the passage of the Statute of 4 Anne had seen considerable agitation regarding the plight of honest insolvents, and indeed Parliament had on several occasions acted to improve the situation of such debtors, albeit without notable impact. As the "Age of Reason" moved into full bloom, thoughtful persons began to recognize a moral distinction between fraudulent debtors and honest but unfortunate traders, a distinction nicely crystallized in the provisions of the Statute of 4 Anne. The importance of commercial credit to the growth of commerce, the possibility of honest losses suffered solely because of the uncertainties of trade, and the corresponding need for merchants to be able to limit their liability, were all recognized....

Id. Blackstone and others, writing approximately half a century after the passage of the 1705 Act, unmistakenly identified concern for the honest debtor as one of the bases upon which the bankruptcy acts rested. Id. 
Bankruptcy Act of 1800 in the United States. ${ }^{57}$ Today, as well, the debtor's interests are at the heart of some arguments that have been advanced to explain and justify the bankruptcy discharge. Discharge can be explained as a humane policy that relieves an honest but insolvent individual from burdensome debt, thereby restoring the debtor's self-worth and promoting morality. ${ }^{588}$ Somewhat related to a humanitarian justification for the discharge, but conceptually distinct, is a policy of rehabilitation or social utility. Under this approach, the discharge is seen as furthering the policy of returning the debtor to productive participation in the economy while removing the disincentive to work caused by excessive debt. ${ }^{589}$ That is, of course, good news for the debtor. But rehabilitation theory focuses mainly on the benefits that the discharge brings to society more generally. ${ }^{590}$ Another instrumental justification for the bankruptcy discharge points to the discharge as a proxy for limited liability that encourages entrepreneurs to take risks and encourages consumers to obtain credit. ${ }^{591}$ Yet

587. See MANN, supra, note 264, at 186 ("[I]t is evident that the purpose behind empowering Congress [pursuant to the Bankruptcy Clause] to establish uniform laws on bankruptcy was to protect debtors - albeit not all debtors - as well as creditors, a dual purpose recognized by at least some participants in the ratification debates.").

588. See Gross, supra, note 9, at 102-03 (discussing discharge based on "humanitarian grounds" and as a part of "a humanely functioning society"); Fresh Start, supra note 583, at 9599 (discussing the "humanitarian theory" of discharge).

589. See Local Loan Co. v. Hunt, 292 U.S. 234, 244 (1934) (stating that discharge is "of public as well as private interest, in that it gives to the honest but unfortunate debtor . . . a new opportunity in life and a clear field for future effort"); Adam J. Hirsch, Inheritance and Bankruptcy: The Meaning of 'Fresh Start', 45 HASTINGS L.J. 175, 206-09 (1994) (providing an economic account of discharge focusing on removing disincentives for debtor to work); Fresh Start, supra note 583, at 94-95 (discussing the "social utility theory" of discharge); Howard, supra note 583, at 1062, 1069 (discussing the "economic rehabilitation" function of discharge that restores "participation in the open credit economy").

590. Id. at 1062, 1069-70 ("Only the rehabilitative purpose of restored participation in the open credit economy remains as a meaningful goal of discharge."). Tabb describes a related aspect of the rehabilitation or social utility theory as repairing the "fabric of society" that is torn during times of "widespread financial ruin and calamity." Fresh Start, supra note 583, at 9495. Tabb also notes that "[t]he nonwaivable aspect of the discharge can be explained by this theory, in that waiver might generate externalities, which debtors might systematically ignore." Id. at 94 .

As in the case of the debtor cooperation model, an empirical case could be made that the rehabilitation paradigm is consistent with procedure theory because the discharge provides net gains for creditors. For example, in the area of consumer bankruptcy it is plausible that most creditors are repeat players as extenders of consumer credit (banks that issue credit cards, automobile finance companies, and landlords among others). Restoring discharged debtors to the credit markets has the effect of increasing the universe of creditworthy customers for those creditors holding discharged claims but who wish to engage in future business with the discharged debtors.

591. See Fresh Start, supra note 583, at 100-03 (discussing the "limited liability" and "economic efficiency" theory); John M. Czarnetzky, The Individual and Failure: A Theory of 
another rationale focuses on the impulsive tendencies of individuals to obtain excessive credit and their systematic underestimation of the risks inherent in credit. ${ }^{592}$ Unsurprisingly, reactions among commentators to this perplexing array of justifications for the discharge have varied. ${ }^{593}$ Moreover, some of the justifications for discharge either do not adequately explain or support, or actually conflict with, the various exceptions to the discharge under current law. ${ }^{594}$

Clearly no consensus exists as to the justification for the bankruptcy discharge and the debtor's corresponding fresh start. Theories abound-some are competing, some are complementary. Interestingly, there does seem to be agreement approaching consensus among many (but not all) academics that the discharge generally is justified, that current law has it about right, and that no major overhaul is needed. ${ }^{595}$ Any attempt here to pose a resolution of the current debates would push this project far beyond its feasible scope.

What, then, can procedure theory offer concerning the bankruptcy discharge? First, it supports the retention, even expansion, of the debtor cooperation paradigm in bankruptcy law. ${ }^{596}$ Second, procedure theory urges that whatever purpose or purposes may be served by the bankruptcy discharge, the discharge should be circumscribed as much as possible without undermining those ends. For example, Jean Braucher and I recently proposed, as a substitute for means testing proposals pending in Congress, ${ }^{597}$ a modification to the discharge provisions featuring a novel approach. ${ }^{598}$ Our

the Bankruptcy Discharge, 32 ARIZ. ST. L.J. 393, 412-15 (2000) (arguing that discharge is justified by the "entrepreneurial hypothesis" that the discharge is a part of the institutional market system that encourages entrepreneurship).

592. See Fresh Start, supra note 583, at 99-100 (discussing Jackson's "systematic overborrowing theory"). See generally JACKSON, supra note 70, at 232-43. For a scathing critique of Jackson's theory of discharge, see Philosophy, supra note 49, at 1356-76.

593. Compare Fresh Start, supra note 583, at 103 (providing that "discharge and its exceptions seem driven, in differing degrees, by a variety of normative policies, some of which conflict .... [A] coherent discharge policy requires a thoughtful and balanced consideration of these different policies."), with Howard, supra, note 583, at 1069 (stating that "discharge . . of non-tort claims should have only one goal - to restore the debtor to economic productivity and viable participation in the open credit economy").

594. See, e.g., supra notes 583-85 and accompanying text (discussing debtor-cooperation theory).

595. See supra note 585 (providing commentary critical of means-testing proposals). But see Edith H. Jones \& Todd J. Zywicki, It's Time for Means-Testing, 1999 B.Y.U. L. REV. 177, 248 (1999) (arguing in support of means-testing).

596. See supra notes 583-85 and accompanying text (discussing the justifications for discharge).

597. See supra note 585 (discussing the effect of discharge).

598. See generally Jean Braucher \& Charles W. Mooney, Jr., Means Measurement Rather 
system would capture postdischarge earned income, assessed along the lines of a progressive income tax, for a period of three to five years following an individual's discharge in Chapter 7. ${ }^{599}$ In effect, the system would assess a progressive bankruptcy surcharge based on a debtor's postbankruptcy taxable income. ${ }^{600}$ It would balance a debtor's interest in a discharge and a fresh start against the normative principle that a debtor that can pay some or all of her prepetition discharged debt should be required to pay. ${ }^{601}$

Limiting the assessment period following bankruptcy to a few years is a concession to political realities, ${ }^{602}$ but procedure theory would support an indefinite surcharge so long as the discharged claims had not been satisfied in full. Thus, procedure theory can inform the dischargeability debates at the margin. But even under an unlimited assessment period, were the debtor never to earn sufficient income for the assessments to be applicable the discharge would be effective to prevent any postbankruptcy collections (the same result as under current law). It follows that there remains a residual tension between procedure theory and the bankruptcy discharge. ${ }^{603}$ As the foregoing summary

Than Means Testing: Using the Tax System to Collect from Can-Pay Consumer Debtors After Bankruptcy, 22 AM. BANKR. INST. J. 6 (Feb. 2003) (proposing modifications to the discharge provisions).

599. Id. at 6,56 .

600. Id.

601. Id. at 6. Even harsh critics of the means-testing proposals agree with this principle. See, e.g., Death, supra note 368, at 13 ("[I]t is hard to argue it is fair to permit people who can repay to skip out on their debts.").

602. And also, perhaps, it is concession to Braucher's views in our jointly authored piece, as she might not support a lengthier period.

603. Another argument for reconciling procedure theory with the discharge focuses on the fresh start cousin of the discharge, exempt property. State laws (and some nonbankruptcy federal laws) provide that a portion of an individual debtor's property is exempt from the reach of creditors, though there is a wide disparity among the state laws. See BAIRD, supra note 404, at 32, 46-47 (discussing the historical progression of exempt property and the irregularity of state rules). Moreover, most states have opted out of the federal exemptions provided in $\$ 522(d)$ of the Bankruptcy Code, thereby making state law exemptions of those states applicable in a bankruptcy case of a resident of one of those states. See TABB, supra note 136, $\S 9.2$ at 643-45 (discussing 11 U.S.C. $\$ 522($ b)(1), which permits states to opt out of the 11 U.S.C. \$522(d) federal exemptions for their residents). Looking to state law-and nonbankruptcy federal law, when applicable - for a debtor's exemptions is fully consistent with procedure theory. Moreover, the argument goes, there are both practical and constitutional reasons why leaving the bankruptcy discharge to state law is not feasible. See supra notes 26566 and accompanying text (discussing state law bankruptcy and insolvency statutes in effect in the absence of a federal bankruptcy law). And, that some states enacted statutes providing for a bankruptcy discharge is some evidence that if the states could provide an effective bankruptcy discharge perhaps they would do so. See MANN, supra note 264, at 203 (discussing the 1790s Connecticut, Rhode Island, and Maryland statutes permitting discharge on special petition to the legislature). This is especially so today inasmuch as the bankruptcy discharge is generally well 
of the theoretical debates suggests, the bankruptcy discharge under current law, including the exceptions to discharge (general and specific), represent compromises among a number of competing values. As Charles Tabb has observed, "[t]he rub, of course, is how to reconcile the conflicting demands of justice and mercy. Justice says that a debtor should be compelled to pay his debts whenever possible.... Mercy says that the debtor should be relieved of his debts."

The bankruptcy discharge is based in part - perhaps in large part-on normative grounds that are independent of procedure theory's concern for the vindication of legal entitlements. As it relates to an individual Chapter 7 debtor, bankruptcy law generally is bifurcated between matters relating to the application of prepetition assets toward the satisfaction of prepetition claims and those concerning the individual debtor's postpetition life, including the discharge and the related injunction. Procedure theory may inform the latter segment, as discussed above, but it addresses and instructs primarily the former. That procedure theory cannot fully explain or justify the bankruptcy discharge, however, in no way undercuts procedure theory's clear normative and explanatory purchase with respect to these other aspects of bankruptcy law, which is its primary focus. ${ }^{605}$

\section{H. Chapter 11 Discharge}

Confirmation of a plan in Chapter 11 "discharges the debtor from any debt that arose before the date" of the order confirming the plan. ${ }^{606}$ Although the discharge

accepted in principle. This argument - that the bankruptcy discharge would be a feature of state law but for the essential need for a single federal system - is similar to the argument supporting the consistency of procedure theory and pro rata sharing. See supra Part IV.C (discussing pro rata sharing). But, unlike pro rata sharing, as to which there are strong reasons to believe that creditors in general benefit from the doctrine, it is not clear that the discharge generally benefits creditors. See supra note 585 and accompanying text (discussing empirical questions concerning debtor-cooperation theory).

604. Fresh Start, supra note 583, at 113. This tension of justice and mercy also can be analyzed in economic terms. A recent economic analysis models the discharge and identifies the tension between the discharge as insurance against low income and the corresponding reduction of a debtor's incentive to avoid becoming insolvent. See generally Barry Adler et al., Regulating Consumer Bankruptcy: A Theoretical Inquiry, 29 J. LEGAL STUD. 585 (2000).

605. Note also that the various theories put forth to justify the discharge provide virtually no guidance whatsoever on the bulk of bankruptcy law, which is unrelated to the discharge. They offer nothing useful in resolving normative and policy questions, such as those raised by the plant closing example and the proposed priority rule discussed in Part III.A-B, or for the understanding of issues such as property of the estate, avoidance powers, or executory contracts and leases. They generally address only one artifact of bankruptcy law (albeit an important artifact for the individual debtor in bankruptcy), the discharge.

606. 11 U.S.C. $\$ 1141(\mathrm{~d})(1)(\mathrm{A})(2000)$. It also "terminates all rights and interests of equity security holders and general partners provided for by the plan." 11 U.S.C. $\S 1141(\mathrm{~d})(1)(\mathrm{B})$ 
appears to override the legal entitlements of a debtor's rightsholders, properly viewed it is fully consistent with procedure theory. Absent consent, under the "best interests" test, confirmation generally requires that each holder of a claim or interest receive property of a value not less than the holder would receive in a Chapter 7 liquidation of the debtor. ${ }^{607}$ This policy is consistent with the goal of reorganization and of procedure theory, to enhance and preserve value for the benefit of the rightsholders. In exchange for the discharge, then, holders of claims or interests receive the modified package of property and rights provided under the plan. ${ }^{608}$

In Chapter 11, as with the nonbankruptcy judicial enforcement of any claim, recoveries are applied to and discharge the claim. But there is a difference with a Chapter 11 discharge because debts are not discharged pro tanto based on the value received as in judicial enforcement outside bankruptcy; they are discharged entirely. While the discharge prevents a rightsholder from maintaining its prebankruptcy legal entitlements indefinitely, as a practical matter that ability would not exist in any event under nonbankruptcy law even in the absence the Chapter 11 discharge. Without the power to modify its financial structure, the debtor would have little incentive to file under Chapter 11. And assuming in most cases that the alternative to reorganization would be liquidation, in Chapter 7 or otherwise, the absence of a discharge in liquidation would represent a distinction without a difference. ${ }^{609}$ Following liquidation, no one could expect that additional investments or operations would provide renewed value for the vestigial "shell" firm.

\section{Priority Claims Under Bankruptcy Code Section 507}

As a general matter, procedure theory regards the priority scheme for unsecured creditors in Bankruptcy Code Section 507(a) to be the most noxious feature of bankruptcy law. ${ }^{610}$ This view is not because that section blatantly

(2000).

607. See 11 U.S.C. § 1129(a)(7) (2000) (establishing the "best interests" test).

608. In Chapters 12 and 13 the discharge normally is not given until the debtor has completed all payments under a confirmed plan, subject to certain exceptions. See 11 U.S.C. $\S \S 1228(\mathrm{a})-(\mathrm{b})$ (2000) (providing the general rule and the exceptions). These discharge provisions are even more faithful to procedure theory than the Chapter 11 discharge, which is given upon confirmation. See supra note 606 (discussing the confirmation of a plan in Chapter 11).

609. The discussion contemplates that the debtor is not an individual. Entities such as corporations do not receive a discharge in Chapter 7. See 11 U.S.C. \& 727(a)(1) (2000) ("The court shall grant the debtor a discharge, unless-(1) the debtor is not an individual.").

610. The priority provisions are not, however, as high on the culpability scale from the perspective of procedure theory as would be the allocation of rightsholders' wealth to benefit the interests of persons or groups when those interests do not consist of legal entitlements - for 
benefits congressional favorites (which it does) ${ }^{611}$ or because the beneficiaries necessarily are undeserving (they may be) ${ }^{612}$ but because it is wrong. ${ }^{613}$ It is wrong for Congress to allocate assets first to those who have no legal entitlements to be paid first under nonbankruptcy law.

There is room for some exceptions to procedure theory's general hostility to bankruptcy-only priority rules. A priority could be justified to the extent that the priority afforded in bankruptcy would have the result of improving, or at least not detracting from, the recoveries and benefits of the rightsholders who are subordinated to the priority claimants. For example, the collective benefits of bankruptcy would be substantially hindered, whether in liquidation or reorganization, were professionals and others who transact postpetition business with the debtor not entitled to an administrative priority under Section 507(a)(1). ${ }^{614}$ Similarly, one might argue that the priority rule for prepetition wage claims provides an incentive for employees to remain on the job and that it thereby furthers the goal of a successful reorganization. ${ }^{615}$

For the most part nonbankruptcy law could, if the relevant lawgivers so wished, accommodate the apparent policies underlying the Section 507(a) priorities. For example, state law or general, nonbankruptcy federal statutes providing for nonconsensual general liens on a debtor's assets could provide substantial protection for employee claims, employee benefit contribution claims, and the claims of grain farmers and fishers. Moreover, liens for taxes under both state and federal law already are common. ${ }^{616}$ Of course,

example, future employment and community interest. See supra Part IIII.A-B (discussing the interests of rightsholders). At least the favored priority claimants hold real claims under nonbankrutpcy law.

611. See 11 U.S.C. $\$ 507(\mathrm{a})(5)$ (2000) (granting fifth priority for certain claims of grain farmers and United States fishers).

612. For example, the third priority rank provided for certain wage claims may recognize that most employees have only one job, making them poor risk spreaders.

613. Cf. GeOrge Orwell, ANIMAL FArm 96 (Penguin Group 1996) (1946) ("All animals are equal but some animals are more equal than others.").

614. See TABB, supra note $136, \S 7.7$, at 494 (discussing priority of administrative claims). This policy does not mean that administrative expense priorities as applied necessarily further the goal of enhancing the benefits for rightsholders. For example, it is entirely possible that the effect of the priority across the entire run of Chapter 11 cases is to deplete wealth to the detriment of rightsholders and to the benefit of professionals.

615. I do not make that argument but mention it only as the genre of explanations that procedure theory could accept. Presumably those who might make this argument are not the ones who argue that keeping their jobs is the paramount concern for employees.

616. See, e.g., 26 U.S.C. $\$ 6321$ (2000) (providing a lien on all of taxpayer's property in favor of United States if taxpayer fails to pay federal taxes). 
exceptions and priority rules might be necessary to accommodate the interests of buyers and secured creditors and the resulting structure might not replicate exactly the Section 507(a) priorities.

Procedure theory would push the argument even further. Given the substantial deference that the Bankruptcy Code gives to nonbankruptcy law with respect to property transfers, ${ }^{617}$ there is no principled reason, given the essentially procedural functions of bankruptcy law, why nonbankruptcy law should not effectively establish priorities that would be binding in bankruptcy. ${ }^{618}$ This approach would contravene not only doctrine but a longstanding cultural aspect of bankruptcy policy. ${ }^{619}$ But on consideration of the general respect that the Bankruptcy Code maintains for nonbankruptcy liens, this move would not be as radical as it might appear at first blush. Moreover, the same argument would apply equally to the creation of nonbankruptcy law statutory liens triggered by insolvency. Of course, respecting those liens would require a modification of Bankruptcy Code Section $545 .^{620}$

The foregoing discussion bears directly on arguments made by a handful of academics that in bankruptcy contract claims (and, perhaps, even secured contract claims) should be fully or partially subordinated to tort claims-the "tort-first" argument. ${ }^{621}$ Elsewhere I have expressed skepticism about the merits of the tort-first proposals. ${ }^{622}$ But procedure theory, by its nature, would assess the tort-first argument while conceding that tort-first could provide a normatively superior regime, whether evaluated on efficiency grounds or on another basis. Yet procedure theory maintains that tort-first proposals are the domain of nonbankruptcy law.

617. See supra Part IV.A (discussing the "Property of the Estate").

618. Presumably, these priorities would apply in the case of insolvency, whether inside or outside bankruptcy.

619. See TABB, supra note $136, \S 7.7$, at 496 ("The states are not permitted to establish priorities that will be effective in bankruptcy cases. The federal priority scheme set out in $\$ 507$ (a) preempts state priorities under the Supremacy Clause of the Constitution."). Even if state-created priorities were generally honored in bankruptcy, federal bankruptcy law should not honor priorities designed to favor one state's residents over another. Otherwise, an important goal of a uniform federal bankruptcy law could be undercut. See supra notes 265-66 and accompanying text (discussing federalism concerns of federal bankruptcy jurisdiction).

620. See 11 U.S.C. $\$ 545(1)$ (2000) (providing avoidance of statutory liens that are triggered by a bankruptcy filing, insolvency, or similar events or conditions).

621. For a review of subordination proposals, see generally Social Costs, supra note 168, at $1349-55$.

622. Charles W. Mooney, Jr., Judgment Proofing, Bankruptcy Policy, and the Dark Side of Tort Liability, 52 STAN. L. REV. 73, 75-76 (1999) [hereinafter Judgment Proofing] (questioning the basis and effectiveness of tort law). 
One apparent advantage of importing a tort-first priority regime into bankruptcy law, even an advantage quasi-procedural in its effect, is the relative convenience of administration in a collective proceeding. This argument follows the same line of reasoning applied to justify and reconcile with procedure theory pro rata sharing in bankruptcy. ${ }^{623}$ It would be easier to administer a priority regime in a collective proceeding than in individual lawsuits (such as a suit grounded in tort) in which the subordinated class of parties (such as general contract creditors) are not involved. ${ }^{624}$ Moreover, it is the scarcity of resources presumed to exist in a bankruptcy case involving an insolvent debtor that would drive the need for a tort-first priority rule.

Procedure theory can marshal several responses to this argument. First, it would be much easier to impose tort-first as a matter of nonbankruptcy law than it would be to impose pro rata sharing. Statutory liens, incorporating a lis pendens feature or other notice systems, are common under nonbankruptcy law. ${ }^{625}$ But pro rata sharing necessarily involves a collective proceeding inasmuch as it affects all unsecured creditors.

Second, unlike pro rata sharing, which is ubiquitous in nonbankruptcy collective insolvency contexts, in the United States there is no nonbankruptcy tradition or historical normative support for tort-first. Instead, nonbankruptcy law must be understood as commanding equality among unsecured creditors, irrespective of the doctrinal nature of those claims, while accepting the race of diligence as an essential component of enforceability in the absence of insolvency. ${ }^{626}$ Pro rata sharing gives effect to the essential equality of unsecured creditors outside bankruptcy. Tort-first, on the other hand, would promote some otherwise equal creditors to the detriment of other, demoted creditors. Moreover, if anything, some nonbankruptcy and bankruptcy doctrine would support a tort-second approach. ${ }^{627}$

623. See supra Part IV.C (discussing pro rata sharing).

624. See Philosophy, supra note 49, at 1380-81 n.123 (discussing the difficulty of "marshaling" assets in a nonbankruptcy case in order to effect a tort-first regime).

625. Procedure theory could accommodate a bankruptcy-only tort-first regime only if it would be virtually impossible or unfeasible to implement the regime under nonbankruptcy law. Some advocates for the partial subordination of security interests have argued that a nonbankruptcy regime is indeed feasible and, perhaps, superior to a bankruptcy-only subordination regime. See generally Lynn M. LoPucki, Should the Secured Credit Carve Out Apply Only in Bankruptcy? A Systems/Strategic Analysis, 82 CORNELL L. REV 1483 (1997); William J. Woodward, Jr., The Carve-Out Proposal and Its Critics: A Response, 30 U.C.C. L.J. 32 (1997).

626. See supra note 477 and accompanying text (discussing pro rata sharing).

627. See Judgment Proofing, supra note 622, at 74-75 (explaining that in many cases when tort claims arise the debtor (tortfeasor) does not receive reasonably equivalent value in connection with incurring the obligation, thereby raising the question whether these tort claims 
Third, similar to but distinct from the second response, tort-first would not affect, but would detract from, procedure theory's goal of enhancing the benefits for rightsholders. It would punish some and reward others. If society wishes to "tax" some to benefit others, then it should adopt a comprehensive across-the-board system for providing benefits to victims of torts, not a bankruptcy-specific redistribution of wealth. ${ }^{628}$

Procedure theory must recognize that it is not merely in bankruptcy that tort-first might have its principal effects. Indeed, advocates generally have pointed to the caution-inducing instrumental effects that they claim would result from a tort-first regime. ${ }^{629}$ Procedure theory alone cannot refute these instrumental arguments. Instead, it maintains that the process of creating bankruptcy law is not the proper crucible for addressing these problems. ${ }^{630}$ I suspect that the likelihood that the process of reforming and administering bankruptcy law will develop pathbreaking and revolutionary solutions, even partial solutions, to the problems of deterring tortious conduct and compensating victims of torts is about the same as the probability that it will improve the world by radically overhauling employment law-slim to none. ${ }^{631}$

Finally, consider the position that objectors to procedure theory must embrace. The counter to procedure theory necessarily must hold that the proper domain for bankruptcy-only priority rules includes any modification of nonbankruptcy entitlements whatsoever so long as the move is socially beneficial and susceptible to better administration (presumably, no matter how slight the advantage) in a collective proceeding. That is a plausible political position for anyone who thinks that they and their ilk might manipulate the bankruptcy reform process to their desired ends. The argument here, however, is not about the merits of proposals such as tort-first but the proper scope of bankruptcy law. The unbounded view of bankruptcy holds that once all of the

may be, or should be, avoidable under fraudulent transfer law). See, e.g., 11 U.S.C. § 548(a)(2) (2000) (concerning constructive fraud); supra Part IV.E.3 (discussing fraudulent transfers). This argument implicates the merits of a tort-first regime but also is compatible with procedure theory's acceptance of nonbankruptcy entitlements.

628. See generally Stephen D. Sugarman, DoIng Away With PERsonal InJury Law (1989).

629. See, e.g., David W. Leebron, Limited Liability, Tort Victims, and Creditors, 91 COLUM. L. REV. 1565, 1637-50 (1991) (discussing how bankruptcy "structure affects the externalization of tort risk, and about the proper liability of debtholders"). For a brief skeptical critique, see Social Costs, supra note 168, at 1364-70 (critiquing the tort-first regime).

630. See supra Part III.E (discussing public choice account of procedure theory).

631. Procedure theory cannot, however, resolve the empirical questions implied by the statement in the text. 
assets and rightsholders are in court, bankruptcy's job is to do social justice without regard to whether it tramples on nonbankruptcy legal entitlements.

\section{J. Adequate Protection for Undersecured Creditors}

Both the trustee in bankruptcy, or debtor in possession, and the holder of a secured claim have a property interest in the property of the estate that is secured by the secured claim. ${ }^{632}$ In effect, a secured claim extends only to the value of the collateral. If that value is less than the claim, the claim is bifurcated into a secured claim (equal to the collateral value) and an unsecured claim for the shortfall or deficiency. ${ }^{633}$ The creditor holding such a secured claim is said to be an "undersecured" creditor. When a debtor in possession possesses and uses a secured creditor's collateral the creditor is entitled to "adequate protection" of its interest in the collateral. ${ }^{634}$ Fully consistent with procedure theory, this right to adequate protection preserves the value of the secured creditor's nonbankruptcy entitlement and avoids a redistribution of that value for the benefit of the unsecured creditors. ${ }^{635}$

Outside bankruptcy the secured creditor would be entitled to enforce its lien, such as by a disposition in a foreclosure proceeding, following the debtor's default. ${ }^{636}$ By virtue of the automatic stay, ${ }^{637}$ however, the secured creditor is denied this opportunity. Is the secured creditor entitled to adequate protection for the delay caused by the stay in this context-for the time value of

632. See 11 U.S.C. $\$$ 506(a) (2000) (discussing the bifurcation between the secured and unsecured portions of allowed claims). The statue provides:

An allowed claim of a creditor secured by a lien on property in which the estate has an interest... is a secured claim to the extent of the value of such creditor's interest in the estate's interest in such property ... and is an unsecured claim to the extent that the value of such creditor's interest ... is less than the amount of such allowed claim.

Id.; see also 11 U.S.C. \$101(37) (2000) (defining "lien" as a "charge against or interest in property to secure payment of a debt or performance of an obligation").

633. 11 U.S.C. $\$ 506$ (a) (2000). If the value exceeds the claim, of course, then the secured claim is equal to the amount of the claim. Id.

634. 11 U.S.C. $\$ 363($ e) (2000). See 11 U.S.C. $\$ 361$ (2000) (explaining and providing examples of "adequate protection"). The "lack of adequate protection" also constitutes "cause" for relief from the automatic stay. 11 U.S.C. \$362(d)(1) (2000). See supra Part IV.D (discussing the automatic stay).

635. This policy views the unsecured creditors as the residual owners of an insolvent firm who stand to gain from a successful reorganization. Adequately protecting the secured creditors means that their assets are not dissipated to benefit the unsecureds who otherwise would be "rolling the dice" with the secured creditors' collateral.

636. This discussion assumes, as is typical, that the debtor is in default.

637. See supra Part IV.D (discussing the automatic stay). 
money? The Supreme Court unanimously answered "no" to this question in United Savings Association v. Timbers of Inwood Forest Associates, LTD. ${ }^{638}$ Although I believe that the court incorrectly decided the case as a matter of statutory interpretation, that is beside the point for present purposes. ${ }^{639}$ The result in Timbers (or in the Bankruptcy Code, assuming a correct interpretation in Timbers) clearly contravenes procedure theory. Outside bankruptcy, the creditor would be entitled to the liquidation value of the collateral on day $X$, and by virtue of the automatic stay, the secured creditor receives the value on day $X$ plus $Y$ and, under Timbers, the creditor is not compensated - adequately protected - for the delay. ${ }^{640}$ The secured creditor's property rights are being sacrificed for the benefit of the unsecured creditors, plain and simple.

The effect of Timbers is not merely wrong, it is outrageous. But even if the Court overrules it or rectifies it with an amendment to the Bankruptcy Code, I suspect that the judiciary often would find the means to offend procedure theory in practice. ${ }^{641}$ Procedure theory provides a normative bottom to argue for a more radical adjustment of the treatment of secured claims in bankruptcy, such as a requirement that the trustee or debtor in possession cure all defaults within a specified period as a condition to retaining possession or control of collateral. $^{642}$

\section{K. Other}

This Part has examined some of the most important features of bankruptcy law. In many respects, it found these features generally compatible with procedure theory, although it also identified some details of current doctrine that cannot be reconciled. Those aspects should be conformed to procedure theory. These aspects of bankruptcy law, while important, nonetheless are

638. United Sav. Ass'n v. Timbers of Inwood Forest Assoc., LTD., 484 U.S. 365, 382 (1988) (holding that "unsecured creditor is not entitled to interest on its collateral during the stay").

639. For an article that predated Timbers and that argued in favor of protecting secured creditors for the time value, see generally Douglas G. Baird \& Thomas H. Jackson, Corporate Reorganizations and the Treatment of Diverse Ownership Interests: A Comment on Adequate Protection of Secured Creditors in Bankruptcy, 51 U. CHI. L. REV. 97 (1984).

640. For a brief, clear exposition of the normative argument against the Timbers result, see TABB, supra note 136, $\$ 3.18$, at 197.

641. See, e.g., Frost, supra note 4, at 93 (noting redistributive effect of Chapter 11 process).

642. Such a scheme could be patterned on the regime for commercial aircraft and ships in Chapter 11 cases in which the debtor is an air carrier or water carrier. See 11 U.S.C. $\$ 1110$ (2000) (stating the Chapter 11 provisions regarding "Aircraft equipment and vessels"). 
illustrative. Much of the legal landscape of bankruptcy remains to be examined through the normative principles of procedure theory.

Additional aspects of bankruptcy law that could be informed by procedure theory include corporate governance and securities regulation in Chapter 11, additional issues relating to what constitutes a claim (including environmental injunctions and covenants not to compete), postpetition financing, equitable subordination, mass torts issues (including Bankruptcy Code Section 524(g), future claims, and third party injunctions and releases), successor liability, additional avoidance and related powers-including statutory liens, turnover orders, postpetition after-acquired property and proceeds, and setoff-federal and state exemptions, and first-day orders under the "doctrine of necessity."

\section{Conclusion}

This Article develops a normative theory of bankruptcy, procedure theory that understands bankruptcy law as a subset of civil procedure law. The proper domain of bankruptcy law is in service to the interests of rightsholders that have a relationship to a financially troubled debtor. Procedure theory holds that it generally is wrong to impair the interests of rightsholders for the benefit of nonrightsholders or to reorder nonbankruptcy priorities in bankruptcy. Procedure theory allows for exceptions to its baseline injunctions when necessary and appropriate for bankruptcy law to fulfill its purpose. It identifies what bankruptcy law should do, in general terms, but it does not resolve the optimal means for a bankruptcy law to achieve its appropriate goals of serving the interests of rightsholders.

Procedure theory does not rely on a simplistic, label-based procedure versus substance dichotomy for its normative content. It draws its normative core from three similar but distinct accounts: The philosophical and jurisprudential account, the civil procedure and federal court jurisdiction account, and the public choice account. Each account condemns the existence of one set of laws applicable in bankruptcy and another applicable outside bankruptcy, unless there is a rational bankruptcy-related basis for a bankruptcyspecific or bankruptcy-only rule.

After establishing the content and normative grounds underlying procedure theory, this Article examines several important features of United States bankruptcy law. It rationalizes the existence of several bankruptcy law deviations from nonbankruptcy law and concludes that there are bankruptcyrelated reasons that justify these deviations. In other cases, however, procedure theory identifies aspects of current bankruptcy law that cannot be justified and 
it calls for change. This Article demonstrates the utility of procedure theory as a framework for a principled critique of current bankruptcy law and of changes to bankruptcy law that might be proposed. 